Culture del lavoro 8

\title{
Through
}

the Working Class

Ecology and Society

Investigated Through

the Lens of Labour

edited by

Silvio Cristiano

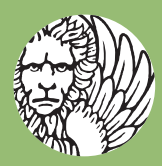

Edizioni

Ca'Foscari

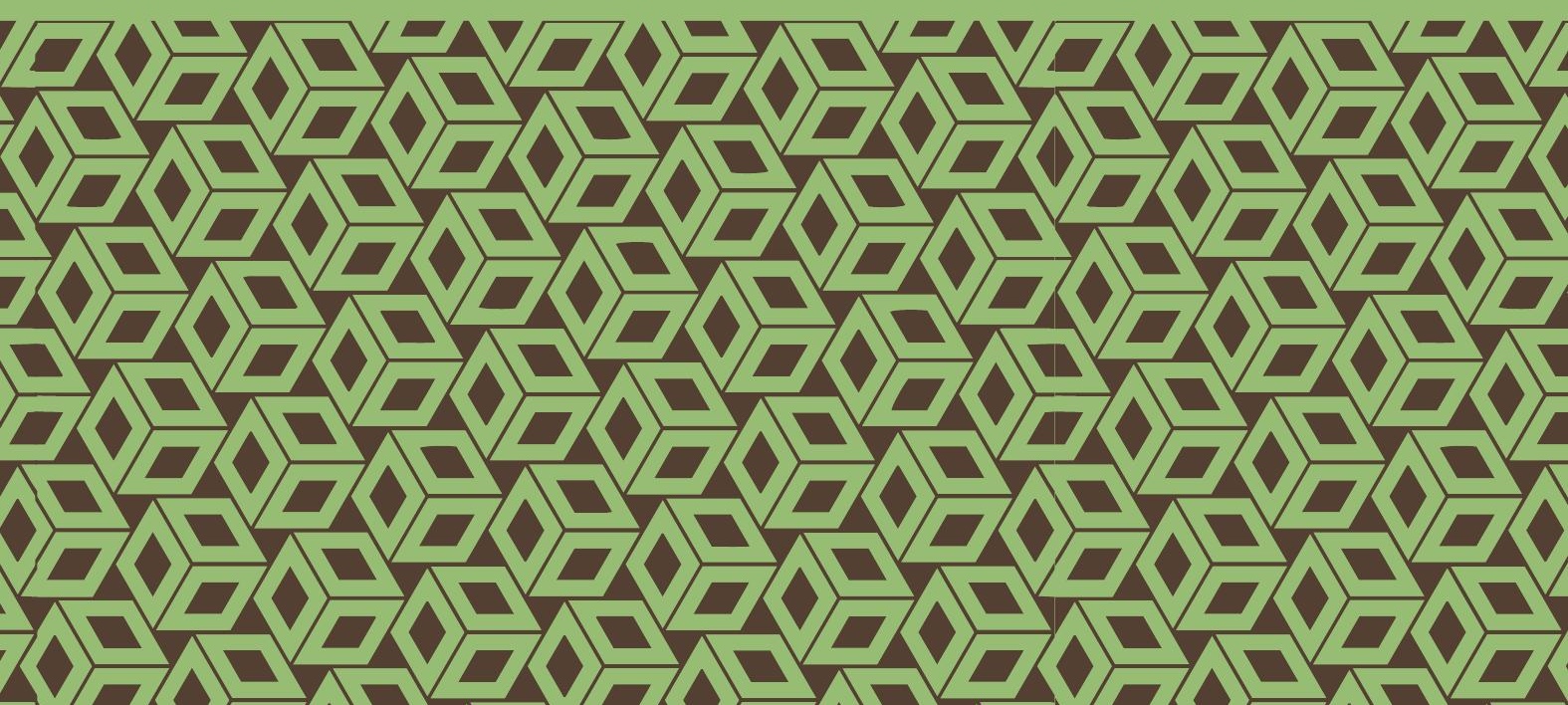



Through the Working Class

\section{Culture del lavoro}

8

Edizioni

Ca'Foscari 


\section{Culture del lavoro}

\section{Comitato editoriale}

Bruno Anastasia (Veneto Lavoro, Regione del Veneto, Italia)

Giovanni Bertin (Università Ca' Foscari Venezia, Italia)

Alfiero Boschiero (IRES Veneto, Italia)

Alessandro Casellato (Università Ca' Foscari Venezia, Italia)

Laura Cerasi (Università degli Studi di Genova,Italia)

Francesca Coin (Università Ca' Foscari Venezia, Italia)

Giancarlo Corò (Univ. Ca’ Foscari Venezia, Italia)

Matteo Ermacora (Università Ca' Foscari Venezia, Italia)

Giovanni Favero (Università Ca' Foscari Venezia, Italia)

Marco Fincardi (Università Ca' Foscari Venezia, Italia)

Giovanni Levi (Università Ca' Foscari Venezia, Italia)

Fabrizio Panozzo (Università Ca' Foscari Venezia, Italia)

Fabio Perocco (Università Ca' Foscari Venezia, Italia)

Rolf Petri (Università Ca' Foscari Venezia, Italia)

Omar Salani Favaro (Università Ca' Foscari Venezia, Italia)

Glauco Sanga (Università Ca' Foscari Venezia, Italia)

Vladimiro Soli (IRES Veneto, Italia)

Giuseppe Tattara (Università Ca' Foscari Venezia, Italia)

Maria Turchetto (Università Ca' Foscari Venezia, Italia)

Gilda Zazzara (Università Ca’ Foscari Venezia, Italia)

Francesco Zirpoli (Università Ca' Foscari Venezia, Italia)

\section{Direzione e redazione}

Alfiero Boschiero

Alessandro Casellato

Giovanni Favero

Gilda Zazzara

Dipartimento di Studi Umanistici

Università Ca' Foscari Venezia

Dorsoduro 3484/D

30123 Venezia, Italia

lav_ecf@unive.it

e-ISSN 2610-9379

ISSN 2610-8852

URL http://edizionicafoscari.unive.it/it/edizioni/collane/culture-del-lavoro/ 
Through the Working Class

Ecology and Society Investigated

Through the Lens of Labour

edited by Silvio Cristiano

Venezia

Edizioni Ca' Foscari - Digital Publishing 2018 
Through the Working Class. Ecology and Society Investigated Through the Lens of Labour Silvio Cristiano (edited by)

(c) 2018 Silvio Cristiano for the text

(C) 2018 Edizioni Ca' Foscari - Digital Publishing for the present edition

\section{(1)(1)}

Quest'opera è distribuita con Licenza Creative Commons Attribuzione 4.0 Internazionale This work is licensed under a Creative Commons Attribution 4.0 International License

Qualunque parte di questa pubblicazione può essere riprodotta, memorizzata in un sistema di recupero dati o trasmessa in qualsiasi forma o con qualsiasi mezzo, elettronico o meccanico, senza autorizzazione, a condizione che se ne citi la fonte.

Any part of this publication may be reproduced, stored in a retrieval system, or transmitted in any form or by any means without permission provided that the source is fully credited.

Edizioni Ca' Foscari - Digital Publishing

Università Ca' Foscari Venezia

Dorsoduro 3246

30123 Venezia

http://edizionicafoscari.unive.it/

ecf@unive.it

1st edition December 2018

ISBN 978-88-6969-296-3 [ebook]

ISBN 978-88-6969-297-0 [print]

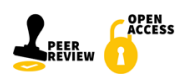

Certificazione scientifica delle Opere pubblicate da Edizioni Ca' Foscari - Digital Publishing: tutti i saggi pubblicati hanno ottenuto il parere favorevole da parte di valutatori esperti della materia, attraverso un processo di revisione anonima sotto la responsabilità del Comitato scientifico della collana. La valutazione è stata condotta in aderenza ai criteri scientifici ed editoriali di Edizioni Ca' Foscari.

Scientific certification of the works published by Edizioni Ca' Foscari - Digital Publishing: all essays published in this volume have received a favourable opinion by subject-matter experts, through an anonymous peer review process under the responsibility of the Scientific Committee of the series. The evaluations were conducted in adherence to the scientific and editorial criteria established by Edizioni Ca' Foscari.

Through the Working Class. Ecology and Society Investigated Through the Lens of Labour / Silvio Cristiano (edited by). - 1. ed. - Venezia : Edizioni Ca' Foscari - Digital Publishing, 2018. - 118 p.; $23 \mathrm{~cm}$. - (Culture del lavoro; 8). - ISBN 978-88-6969-297-0. 
Through the Working Class

Ecology and Society Investigated Through the Lens of Labour

edited by Silvio Cristiano

\section{Table of Contents}

Preface

Systemic Thoughts on Ecology, Society, and Labour

Silvio Cristiano

Ecologies of Labour

An Environmental Humanities Approach

Stefania Barca

Subaltern Environmentalism in Can Sant Joan, Catalonia

Sergio Ruiz Cayuela

Urban Social Movements in Rio de Janeiro

The 'Missing' Environmental Question

Federico Venturini

Othered Bodies and Ecophobia

Mamak Garbage Area

Zümre Gizem Yılmaz

Turning Modernity Upside Down

La Belle Verte, Island and the Making of Non-capitalist Ecologies

Rocio Hiraldo Lopez-Alonso

Literary Representations of Human-Nonhuman Labour Collaborations

Fatma Aykanat

Beyond the Dark, Satanic Mills

An Ecocritical Reading of 'A Kestrel for a Knave'

Joanna Dobson 



\title{
Through the Working Class
}

Ecology and Society Investigated through the Lens of Labour

edited by Silvio Cristiano

\begin{abstract}
"Would you tell me, please, which way I ought to go from here?" "That depends a good deal on where you want to get to," said the Cat.
\end{abstract}

(Lewis Carroll, Through the Looking Glass, 1871)

\section{Preface}

The present volume offers a mosaic of contributions by scholars from different backgrounds, providing a multi-faceted, problematising picture of relations among humans as well as between the human and the nonhuman, investigated by environmental studies and social ecological perspectives, and involving labour. In turbulent times like these, systems ecology, political ecology, social ecology, ecocriticism, ecofeminism, environmental justice, and environmental humanities here follow and interlink one another, thus offering plural insights around the themes of society and ecology, while more or less explicitly envisioning a sustainable and equitable transformative path past the social, ecological, and sometimes psychological unbearableness of current modernities.

\section{Acknowledgements}

The occasion for all the authors to meet and put together their works into the present volume was the $5^{\text {th }}$ Annual Workshop of the Postgraduate Forum Environment, Literature, Culture, titled 'Working-class Environmentalism: Reframing the Interface between Nature and Society', hold in Venice, Italy, on 9-10 November 2017, and partially funded by EASLCE - European Association for the Study of Literature, Culture and Environment, the Rector's Office and the Special Projects Office of Università $\mathrm{Ca}^{\prime}$ Foscari Venezia, the Department of Foreign Languages and Literatures and Modern Cultures of Università degli Studi di Torino, and IRES Veneto-Istituto di Ricerche Economiche e Sociali. The Editor would like to thank Drs. Maria Pia Arpioni, Enrico Riccardo Orlando, Stefania Barca, Gilda Zazzara, Laura Vallortigara, Arianna Ceschin, and Prof. Serenella Iovino for their lovely support in making this happen.

Culture del lavoro 8 ISSN [online] 2610-9379| ISSN [print] 2610-8852

ISBN [ebook] 978-88-6969-296-3 | ISBN [print] 978-88-6969-297-0

(c) 2018 | ()( Creative Commons Attribution 4.0 International Public License 



\author{
Through the Working Class \\ Ecology and Society Investigated Through the Lens of Labour \\ edited by Silvio Cristiano
}

\title{
Systemic Thoughts on Ecology, Society, and Labour
}

\author{
Silvio Cristiano \\ (Università degli Studi di Napoli «Parthenope», Napoli, Italia; \\ Università Ca' Foscari Venezia, Italia)
}

\begin{abstract}
The present contribution provides a tentative conceptual framework, rooted in systems thinking, to analyse the relations between ecology and society as a starting point to possibly address the interconnected crises by which they are affected. Such framework is also intended to offer a common denominator for the other contributions of this volume; as in most of them, an important role is bestowed upon work and labour as leveraging social and economic agents able to (positively and negatively) shape and reshape nature, society, and culture.
\end{abstract}

Summary 1 Nature, Society, and Labour. - 2 A Systemic View of Society, Environment, and Culture. 3 Thoughts, Perspectives, and the Significance of the Chapters of this Volume.

Keywords Systems thinking. Political ecology. Social ecology. Labour. Energy systems language.

\begin{abstract}
"Fine to think we can go on being socially useful even after we're dead. Making plants grow."

Lenina, meanwhile, had turned her eyes away and was looking perpendicularly downwards at the monorail station.

"Fine," she agreed. "But queer that Alphas and Betas won't make any more plants grow

than those nasty little Gammas and Deltas end Epsilons down there."
\end{abstract}

(Aldous Huxley, 'Brave New World', 1932)

\section{Nature, Society, and Labour}

Manual labour has been proposed as the main interface between society and nature (Barca 2014) - or better, by considering the actual embeddedness of the first into the latter, ${ }^{1}$ we could reformulate into 'between soci-

1 As for instance in the well-known diagram by Scott Cato 2009.

Culture del lavoro 8 ISSN [online] 2610-9379| ISSN [print] 2610-8852

DOI 10.30687/978-88-6969-296-3/001 | Submitted: 2018-07-20 | Accepted: 2018-08-29

ISBN [ebook] 978-88-6969-296-3 | ISBN [print] 978-88-6969-297-0

(c) 2018 | (1) Creative Commons Attribution 4.0 International Public License 
ety and the rest of nature'. The current ecological crisis ${ }^{2}$ (ongoing since several decades in spite of - or maybe right because of - palliatives such as sustainable development and green growth ${ }^{3}$ ), overlapping with the umpteenth economic and financial crisis underway (that might be seen as cyclical or chronic, e.g. in Day 2018), represents - following Barca (2012) - an opportunity to rethink production so as to imagine a labour culture able to be socially and ecologically sustainable. This could happen by imagining and of course practicing political actions to defend humans and nature altogether (Barca 2012).

Together with an overall re-politicisation of the debate on socio-ecological transformation, as called for by Demaria et al. (2013), we could argue that a re-politicisation of the debates on labour is also needed toward such change. Heikkurinen et al. (2018) propose that a desired increase in political action necessarily implies considering the energy (and, we could add, the time) subtracted to desired change by current notions and levels of work and labour, and therefore inviting to imagine ways to break free from the monetisation ${ }^{4}$ of work, labour, and action imposed by the current economic model - pursuing an unlimited economic growth - and apparently still widely unquestioned.

Even leaving apart the issue of the exploitation of labour per se, laying at the basis of the creation of profit, sure enough the patent ecological consequences of unlimited profit-seeking production cause damages on the entire human-nonhuman sphere, but it is also true that the first to suffer from such damages are the subaltern classes in light of power relations within society, hence the expressions 'class ecology' and 'power ecology' coined by Bettini $(1976,5)$.

It is in this context that an increasing interest has been shown in the past few years for what has been defined as working-class environmentalism (Barca 2012): albeit particularly marginalised after decades of neoliberalism, working classes - and subaltern classes in general - are the first to suffer the damages of a pursued unlimited economic growth and labouroriented existences (e.g. risky and insalubrious neighbourhoods, unhealthy food, etc.) for which they sometimes become unconsciously co-responsible under the constraint of their salary; maybe not so immediately detectable yet perhaps more sincere than a bourgeois environmentalism, the working

2 Masterfully described, among others, by Commoner 1971; 1975 and by Commoner and Bettini 1976.

3 For a critical overview, see e.g. Büscher et al. 2014; Fuentes-George 2013; Latorre et al. 2015; Leonardi 2017; Cristiano 2018.

4 On this topic, Heikkurinen et al. effectively quote the Manifesto of German group Krisis (1999): "Instead of radically criticising the transformation of human energy into money as an irrational end-in-itself, the workers' movement took the 'standpoint of labour' and understood capital valorisation as a neutral given fact". 
class ecological consciousness shows specific features, since it directly and explicitly interlinks on the foreground the protagonist subjects of the productive process and the places where production happens and where workers and their families live, and on the background the means of production as well as the finalised products.

The very results of production, in the form of production surplus, have been proposed as representing the outcome of the society-nature relation (Zinoni 2000,4), in accordance with the comprehension of the essentials of energy conservation and entropy, i.e., assimilating the thermodynamic implications in daily life (Zinoni 2000, 4). Basing on this, if we slightly zoom out to the transdisciplinarity and environmental humanities ${ }^{5}$ presupposed by the considerations made so far and offering a convergence of disciplines into the rest of the present volume (among others, environmental history, ecocriticism, political ecology, cultural anthropology, and social ecology), a particular reference is made in the present contribution to systems ecology (Odum 1983) and its energy systems language. ${ }^{6}$

To shortly justify this, it could be worth to remind that environmental humanities engage with a major guiding theme such as connectivity (Rose, Robin 2004) and that an ontology of connectivity implies mutual causality: organisms and their environment modify each other through recursive relations (Rose, Robin 2004) - i.e., following Bateson's teachings, with events continuously entering into, becoming entangled with, and then re-entering the universe they describe (Harries-Jones 1995, 3) - thus requiring a systemic view allowing for the analysis of direct and indirect influences and feedbacks, also able to catch the frequent non-linearity of connections; at the same time, in ecological systems the laws of thermodynamics have clear consequences (Hannon et al. 1991, 80).

On these premises, systems ecologist Howard T. Odum proposed the energy systems language (1994). It is beyond the purposes of the present work to explain such language in detail, including its major application, brought about with the concept of emergy (Odum 1996; Brown \& Ulgiati 2016a; 2016b); however, it might be worth to recall, as pointed out in another contribution (Gonella et al., forthcoming), the potential of systems ecology, emergy, and their language as general epistemological tools,

5 Or 'ecological', as for instance per the invitation by Rose and Robin (2004), highlighting how the ecological crisis stands between the natural and cultural spheres, with traditional academic division between humanities and sciences representing a major problem, in company of the general placing of western - or we might prefer 'Global Northern' - science "at the top of an epistemological ladder", all of this limiting our capacity to share knowledge across "fields of plural and diverse knowledges".

6 After all, as suggested by the Internazionale Situazionista (1992), a different language has to be considered for a lucid, critical analysis of the reality out of the dominion and conditioning of the mainstream; in this case, the energy systems language helps us reconnect to the functioning of the society-ecology relations, out of the tricky mediation of money. 
whose often underestimated philosophical potential allows to investigate "deep aspects of the reality as a whole", shedding light onto manifold discio plines, "in the holistic framework of an integrated and 'universal' culture".

\section{A Systemic View of Society, Environment, and Culture}

As extensively explained in his Environment, Power, and Society for the Twenty-first Century: the Hierarchy of Energy (2007), Odum's teachings can be employed to describe and understand society. Building on this, a presentation will follow, supported by diagrams drawn by means of purposely very basic energy systems language, so as to ease their popularisation without the need of an energy systems language background, especially thanks to their embeddedness in the written presentation. ${ }^{7}$
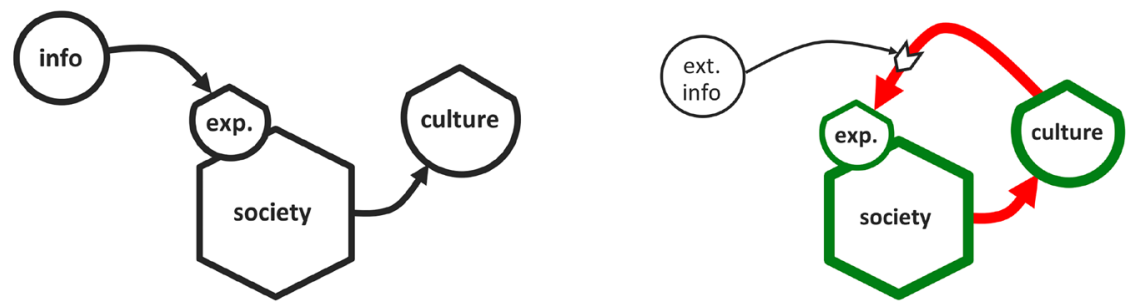

Figures $1 a$ (left) and $1 b$ (right). Basic relation between society and culture

In fig. 1a, the elemental functioning of the production of a culture is shown: a society receives information while interacting with its surroundings and with its experiences ('exp.'), thus elaborating its culture, which in turn (fig. 1 b) influences future experiences while interacting with new information that we might now define as external. Some societies have a very strong culture and/or few contacts with the outside, and this creates a significant feedback between culture and experiences (as highlighted in fig. 1b). This seems to be the case of traditional societies, while modern societies tend to be more subject to the influence of external information (and sometimes direction). Traditionally (fig. 2), the culture of a society would be needed for a conscious use of the resources upon which the society can rely, and its

7 The overall ideas and related diagrams that follow were prepared by the Author and Editor for the contribution at issue, and partly presented within his wider keynote speech 'Cultures, between Global North and Global South. Systemic thoughts toward a socio-economic transition', given during the First North-South Conference on Degrowth-Descrecimiento 'Decolonising the Social Imaginary', hold in Mexico City, 3-7 September, 2018. 
resulting basic economy - a subsistence economy - would appear as ecologically sustainable, while pursuing the wellbeing of the society, which we could see as individual and collective fulfilment and happiness and which provides a reinforcing feedback that we might call social sustainability.

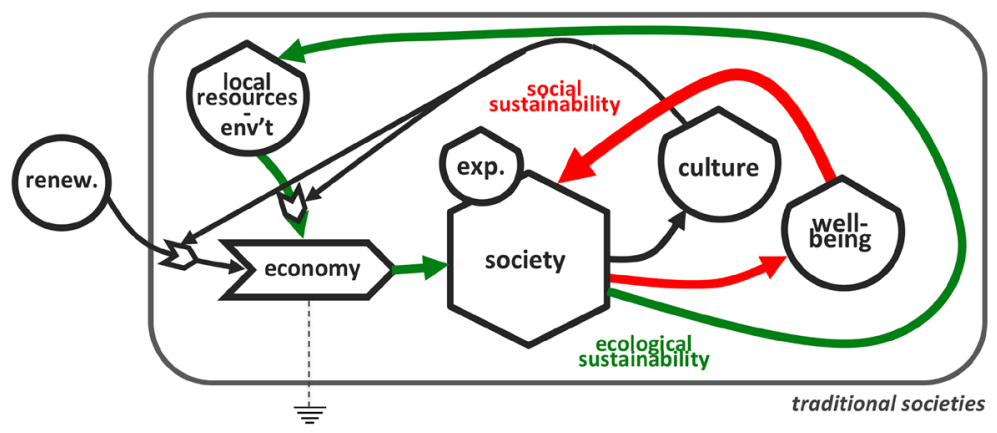

Figure 2. Relations among society, culture, and environment in a traditional society

In modern neoliberal societies (fig. 3), we know that the economy is generally directed from the outside - heterodirected - by means of an ideological narrative that is the result of an economic model de facto imposed also through the expedient of the public debt (see for instance Bersani 2017, 2018). Economic model and public debt contribute to generate and justify an economic growth imaginary ('myth' in the diagram), which clearly influences the culture of a society. In a society like this, still bound to an economic model created upon the denial that human societies and their economies are part of the environment, the notion of waste is introduced, ecologically non-existing in nature after millennia of trial-and-error processes: the idea of ecological sustainability is therefore a mirage not reachable until the circle is closed again (see Commoner 1971). It might be interesting to note that, to allegedly solve an economic debt, an ecological debt is caused - with the effects for not paying off the latter are likely to be much worse than those for not liquidating the former (it might be worth to remind that, inasmuch focused on money, the economic debt is something that simply does not exist from a geobiophysical perspective).

The systemic main goal $^{8}$ of a modern society like the one at issue (fig. 4) changes from wellbeing to wealth, only or mostly measured through

8 The systemic goal might not overlap with the declared goal, but systems thinking invites to analyse a system for its behaviour, not for its narrative. 


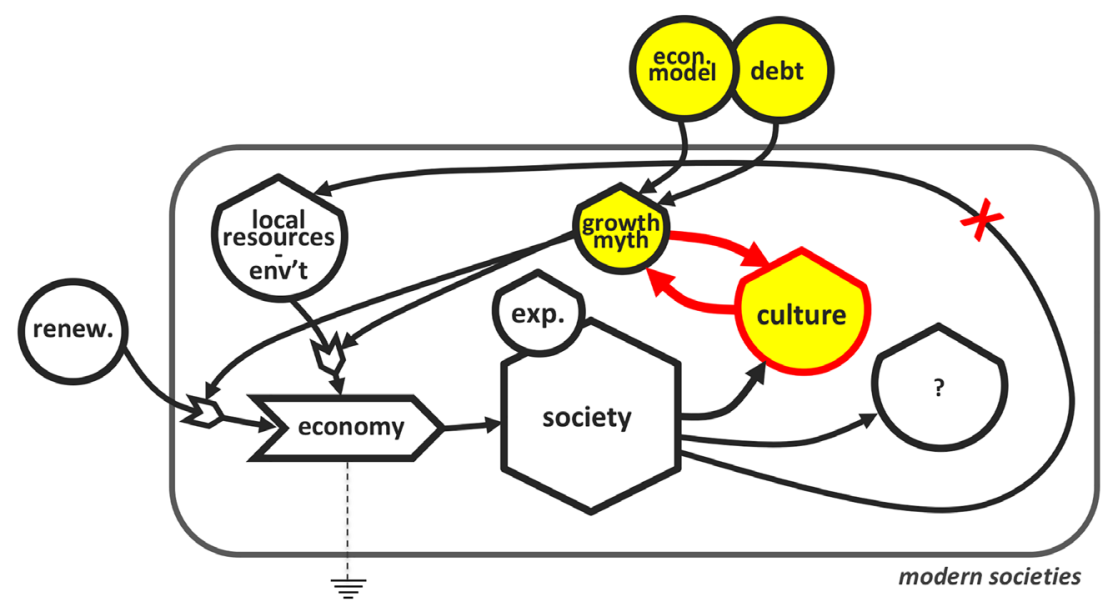

Figure 3. Relations among society, culture, and environment in a modern society: focus on external conditioning

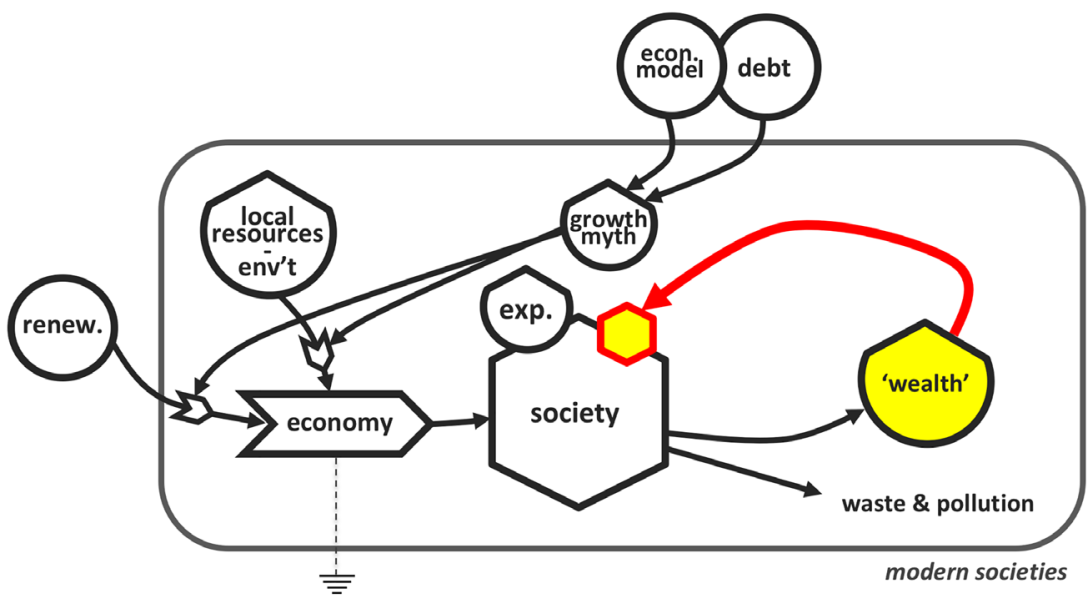

Figure 4. Relations among society, culture, and environment in a modern society: focus on the societal main goal 
financial means and concentrated in the pockets of a minority, ${ }^{9}$ following a renowned pyramidal social organisation, opposite to the wealth concentration pyramid, which is perhaps not even a pyramid yet another geometrical figure following some exponential distribution. Social sustainability starts to be affected here. Moreover, the features of such systemic goals are quite individualist, and it might be worth to recall Arendt's reflections on modern subjectivism, described as contributing to the progressive alienation of humans from the world ([1958] 1998, 272, as cited by Heikkurinen et al. 2018).

Such societies also depend on nonrenewable resources (driving the industrialisation that substantially gave them their current shape) as well as on cheap labour, which usually requires resorting to the South: the Global South, the South of the Global North, or just the subaltern classes within the same society. A significant portion of the drivers of our societies passes through some form of exploitation (fig. 5): human direct exploitation, direct exploitation of other animals, or direct exploitation of nonrenewable (and sometimes also renewable) resources implying - upstream - indirect exploitation of humans and non-humans for their coemption and use, and - downstream - frequent injustice due to the unequal distribution of waste, pollution, and other environmental effects (e.g. due to climate change) within society and within the larger Earth system.

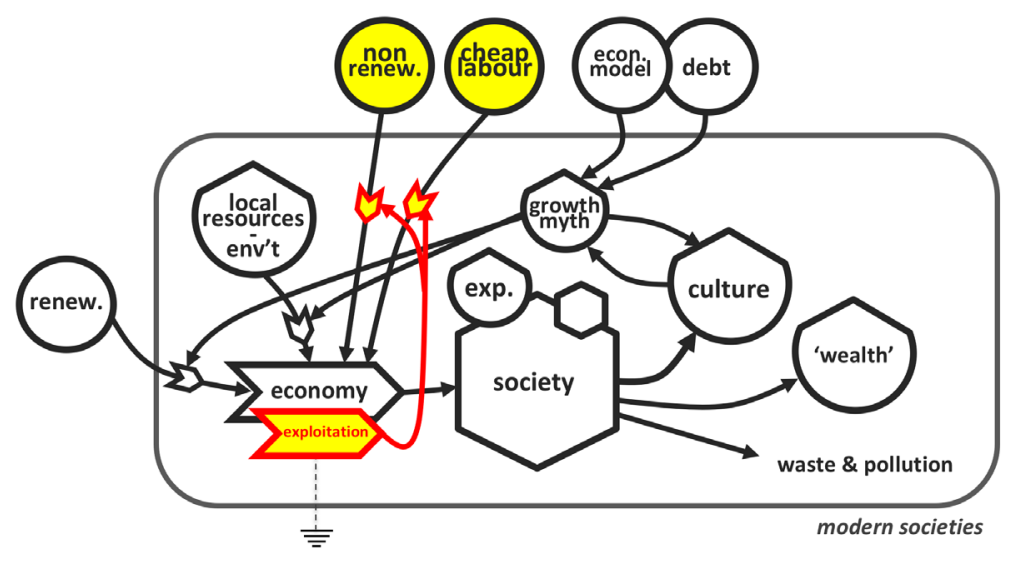

Figure 5. Relations among society, culture, and environment in a modern society: focus on required external inputs

9 Often showing the features of the white well-educated heterosexual male (see Barca's contribution in this volume). 


\section{Thoughts, Perspectives, and the Significance of the Chapters of this Volume}

From a systemic point of view, the origins of the unsustainability of a modern society seem to lie on its driving economic model rather than on the yet problematic ratio of used renewable/nonrenewable resource flows, ${ }^{10}$ and involve social issues such as human exploitation, unequal distribution of the societal benefits, and the very creation of a desire for these benefits - required to keep the system working as it is. ${ }^{11}$ More in general, one of the major defects can be found in the systemic goal, being: material and mostly measured by money (thus not satisfactory per se, see the famous happiness-income paradox, as recalled and updated by Easterlin et al. 2010); heterodirected, depending on a prescriptive information input instead of being set independently, and only consequently attract inputs; and designed for a minority only (thus providing the system with a very partial, so extremely dissipative and feeble, positive feedback).

Addressing such points seems to necessarily involve a questioning of the triggering economic growth, only aimed at increasing the wealth of a minority in light of the very systemic structure, granted that - however, as noted above - wealth does not necessarily correspond to happiness. Besides, speaking of systemic structure, a disproportioned affluence seems only able to magnify the ecological unsustainability of the system; this is why, even from a pure ecological perspective, the issue of the social acceptability of inequality (and of the luxury it generally brings) appears as a crucial one: an individual change in the lifestyles of the middle class (or sometimes even lower classes) might of course be important to slow down the rhythms of the economic system, but apparently is not enough if we think that most of the wealth flows to a minority.

Of course the discussion provided in the previous section is not an invitation to restore a subsistence economy, but rather to trace back the origins of unsustainability in order to rethink our societal priorities, maybe starting from resetting the very societal goal. Shifting from a quantitative to a qualitative analysis, the issue of exploitation could acquire a larger importance, for its ability to consider injustice towards the non-human as well as within and across human societies, including the individual

10 However activated by such economic model.

11 As already noted in Cristiano (2018), a crucial issue can be found in the human pseudoneeds (Debord 1967, Thesis 51) continuously proposed (or - we could say - imposed and mostly internalised) in the mainstream society to maintain the pseudo-need for an ever accelerating societal metabolism (i.e, unlimitedly increasing patterns of production, consumption, resource use, and waste generation) and for the labour upon which it is based. It seems here natural to also refer to Arendt's thoughts on the fact that labour and consumption are aspects of the same process ([1958], 1998, 126). 
psychological level. The manifold interlinks between society and ecology highlighted so far cannot but reinforce the need for an integrated approach between science and humanities, as proposed in the present volume. Within such exploitation issue and in the whole system in general, labour seems to play a leveraging role, for its ability to (positively and negatively) shape and reshape nature, society, and culture, while activating, sustaining, and reinforcing the whole system.

A leverage point like labour can be used as a lens to investigate different aspects of the world, as is after all the case in the present contribution, and - in a perspective of change - as a triggering agent of radical transformation of the reality. It is in this perspective that we can read the increasing proposals for an unconditional basic income and for a maximum acceptable income (Liegey et al. 2013) and for working hour reduction to save time and energy for other activities - relations, care, arts, politics, and non-lucrative action in general - while rethinking both paid and non-paid activity in physical (labour) and social (work) terms and experimenting out of the monetary transactions and the debt-based society, as recently noted by Heikkurinen et al. (2018), who also mention communitysupported agriculture (see e.g. Lamb 1994) as a promising groundbreaking intuition in this direction.

It seems clear that the key role of labour is true irrespective of the societal will to remunerate it, since - from a systemic perspective with geobiophysical foundations - labour is required anyway, and the system would not function without it. From a feminist point of view, this is made clear e.g. in Stefania Barca's contribution, where the notion of labour is enriched beyond mere production, thus involving also reproduction and care, and the economy is compared to an iceberg, with only a small part of the overall work being made visible (following Gibson-Graham 2006). However, this is also something natural in emergy approach, ${ }^{12}$ shifting from a receiver-side to a donor-side approach (see for instance Gonella et al. 2017), i.e., from the value bestowed to a good or a service by the final user - usually (and erroneously) represented by price - to that related to the very possibility to have that good or service delivered: a sort of memory ${ }^{13}$ (fig. 6) of what was required as well as what would be needed for its replacement, and indeed a different idea of value ${ }^{14}$ breaking free from the market.

12 The incorporation of care and voluntary work through the emergy concept is addressed in a number of researches in which the Author was involved: Cristiano 2018; Cristiano et al. 2017, 2018; Gonella et al. 2018.

13 Emergy was originally referred to as 'energy memory', although also able to track matter, information, and labour.

14 Rethinking the idea of value starting from a donor-side perspective involving the memory of what is needed to make something (at least energy, matter, information, and labour - in all its meanings) would also seem as a crucial aspect to address while proposing 


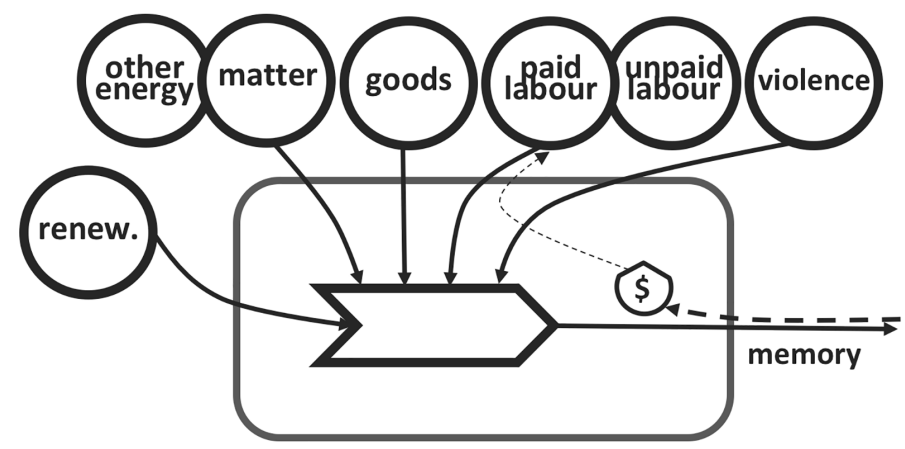

Figure 6. Schematic diagram of memory as addressed in a donor-side perspective

Back to Stefania Barca, her contribution proposed in the next chapter could represent the natural evolution of these premises, while standing out as a masterly theoretical keynote opening to the present volume. In the remaining contributions, more practical examples are reported, all detecting and depicting different experiences of societal and human-non-human issues, and more or less explicitly useful for us to envision a sustainable and equitable change past the social, ecological, and sometimes psychological unbearableness of current modernities.

After Barca, a critical reflection on subalternity and environmentalism is offered by Sergio Ruiz-Cayuela's contribution through an analysis of a working-class migrant neighbourhood in Catalonia facing the consequences of an incineration plant. The link between conditions of social subalternity and ecological disasters - as recalled by Federico Venturini in this volume - is a key aspect in social ecology; this is why he was led to investigate the absence of an overt environmental question in recent (2013-2016) urban social movements in Rio de Janeiro, Brazil, in spite of increasing environmental issues in the area: because of a society with a marked class division, priority seemed to be given to fight class domination.

However, a blur boundary emerges from the definition of 'environmental question', since some elements presented in Venturini might fall instead

alternative currencies. A step even further could be represented by the involvement of the idea of violence, or exploitation (as also defined in the previous section). 
in what Martínez-Alier defines the environmental movements opposing the very material 'effluents of affluence' $(1995,9)$ or rather in what Guha and Martínez-Alier started to define 'environmentalism of the poor' (Maro tínez-Alier 2014). For seek of completeness, besides that related to the COMPERJ petrochemical complex, illustrated by Venturini and showing a high level of conflict, two more cases with lower levels of involvement are reported in the Environmental Justice Atlas (Temper et al. 2015) for the city of Rio de Janeiro and its immediate surroundings: the first one falls within the category 'tourism recreation' and is represented by the case of Horto, where a resistance is happening against 'green gentrification' in the low-income neighbourhood close to the upper middle-class area on the hill sides of the Serra da Carioca; the second one deals with the struggle for the remediation of the chemical contamination in the neighbourhood of Cidade dos Meninos, in Duque de Caxias.

Another interesting contribution addresses the ecophobic discourse arising in the problematic landfill area of Mamak, in Ankara, Turkey, with humans blaming nature for spoiling human practices and plans even in the presence of clear human responsibilities (Yllmaz in this volume), with ecophobia targeting human bodies closely affected by what Martínez-Alier (1995) defines as the 'effluents of affluence'. This was stunningly already present in Italo Calvino's novel Smog (1958, 2010), probably a forerunner of environmental humanities: here - paradoxically - "whereas the proe tagonist is forced to verbally counter and even 'mitigate' the intensity of atmospheric pollution, smog is as a matter of fact a ubiquitous molecular presence saturating literally every corner, especially in and around his body" (Iovino 2017), driving him obsessive-phobic for dust not conceding him any safe shelter.

Literature is after all the protagonist of the rest of the present volume. Rocío Hiraldo's contribution analyses a book by Aldous Huxley and a movie by Colin Serreau, and through them questions ecomodernist socialism while inviting us to reject modern societies from their foundations as well as to overcome "what Marx called alienation from species-being, which involves conceiving ourselves and living as belonging to greater (human and non-human) whole" as well as adopting "communitarian economic systems based upon an even distribution of work". Human and non-human labour is the focus of Fatma Aykanat's contribution, exploring Turkish novels and poems from the nineteenth century while analysing socio-cultural transformation at the dawn of industrialisation. Finally, Joanna Dobson analyses the relationships between human and non-human in industrialised capitalism through an ecocritical reading of a mid-twentieth century novel on working-class life in a mining village in Northern England.

In turbulent times like ours, the contributions of the present volume offer a succession (and often an interlink) of systems ecology, political 
ecology, social ecology, ecocriticism, ecofeminism, and environmental justice, providing plural insights around the themes of society and ecology. An interesting mosaic is offered, showing multiple aspects of the key role played by paid and unpaid labour in the relations between society and the rest of nature. By suggesting paths to re-shape our cultures in a direction of actual social and ecological sustainability and to consequently re-think the role and the features of work and labour, the contributions of this volume more or less explicitly envision a sustainable and equitable transformation past the social, ecological, and sometimes psychological unbearableness of current modernities.

\section{Bibliography}

Arendt, Hannah [1958] (1998). The Human Condition. Chicago: University of Chicago Press.

Barca, Stefania (2012). “On working-class Environmentalism: a Historical and Transnational Overview”. Interface: a Journal for and about Social movements, 4(2), 61-80.

Barca, Stefania (2014). "Laboring the earth: transnational reflections on the environmental history of work". Environmental History, 19(1), 3-27.

Bersani, Marco (2017). Dacci oggi il nostro debito quotidiano. Strategie dell'impoverimento di massa. Roma: DeriveApprodi.

Bersani, Marco (2018). “C’è vita oltre il debito?”. Comune-info, 28 April. URL https://comune-info.net/2018/04/ce-vita-oltre-debito/.

Bettini, Virginio (1976). “Ecologia di potere, ecologia di classe nel caso Icmesa”. Commoner, Barry; Bettini, Virginio (a cura di), Ecologia e lotte sociali. Ambiente, popolazione, inquinamento. Milano: Feltrinelli.

Bird, Rose Deborah; Libby, Robin (2004). "The Ecological Humanities in Action: an Invitation”. Australian Humanities Review, 31(2).

Brown, Mark T.; Ulgiati, Sergio (2016). “Assessing the Global Environmental Sources Driving the Geobiosphere: A Revised Emergy Baseline". Ecological Modelling, 339, 126-32.

Brown, Mark T.; Ulgiati, Sergio (2016). “Emergy assessment of Global Renewable Sources". Ecological Modelling, 339, 148-56.

Büscher, Bram; Dressler, Wolfram; Fletcher, Robert (eds.) (2014). Nature Inc.: Environmental Conservation in the Neoliberal Age. Tucson: University of Arizona Press.

Calvino, Italo (1958). La nuvola di Smog e La formica argentina. Torino: Einaudi.

Calvino, Italo (2010). Difficult Loves. London: Random House.

Commoner, Barry (1971). The Closing Circle: Nature, Man, and Technology. New York: Random House Inc. 
Commoner, Barry; Bettini, Virginio (1976). Ecologia e lotte sociali. Ambiente, popolazione, inquinamento. Milano: Feltrinelli.

Commoner, Barry (1990). Making peace with the planet. New York: Pantheon Books.

Cristiano, Silvio (2018). Systemic Assessment for Sustainable Design - LCAbased Emergy synthesis of an EMERGENCY NGO hospital in Sudan [PhD thesis]. Venezia: IUAV.

Cristiano, Silvio; Elia, Christian; Gonella, Francesco; Nannini, Emanuele; Ulgiati, Sergio (2017). “Downscaling the Need for Common Resources while Saving Money. Lessons from an Innovative Socio-sanitary Structure Run by a Humanitarian NGO: Emergency's Salam hospital in Khartoum, Sudan”. Abstract of the Proceedings of the 12th Conference of the European Society for Ecological Economics (Budapest, Corvinus University, 20-23 June 2017).

Cristiano, Silvio; Gonella, Francesco; Nannini, Emanuele; Spagnolo, Sofia (2018). "Care before business: on the potential of emergy analysis to address the sustainability of not-for-profit systems". Poster presented at the 10th Biennial Conference Emergy and Environmental Accounting. Theories, Applications, and Methodologies (Gainesville, University of Florida, 25-27 January 2018).

Day, Richard B. (2018). “Introduction”. Preobrazhensky, Evgenii Alexeyevich, The Decline of Capitalism. London: Routledge.

Debord, Guy (1967). La societé du spectacle. Paris: Buchet/Chastel.

Demaria, Federico; Schneider, François; Sekulova, Filka; Martínez-Alier, Joan (2013). "What is degrowth? From an Activist Slogan to a Social Movement". Environmental Values, 22(2), 191-215.

Easterlin, Richard A.; McVey, Laura Angelescu; Switek, Malgorzata; Sawangfa, Onnicha; Zweig, Jacqueline Smith (2010). "The Happinessincome Paradox Revisited". Proceedings of the National Academy of Sciences, 22463-8.

Fuentes-George, Kemi (2013). “Neoliberalism, Environmental Justice, and the Convention on Biological Diversity: How Problematizing the Commodification of Nature Affects Regime Effectiveness". Global Environmental Politics, 13(4), 144-63.

Gibson-Graham, Julie-Katherine (2006). A Postcapitalist Politics. Minneapolis (MN): University of Minnesota Press.

Gonella, Francesco; Elia, Christian; Cristiano, Silvio; Spagnolo, Sofia; Vignarca, Francesco (2017). "From Head to Head: An Emergy Analysis of a War Rifle Bullet”. Peace Economics, Peace Science and Public Policy, 23(2). Gonella, Francesco; Cristiano, Silvio; Spagnolo, Sofia (forthcoming). "Emergy as a tool for an integrated knowledge". Emergy Synthesis 10: Theory and Applications of the Emergy Methodology. Proceedings of the 10th Biennial Conference Emergy and Environmental Accounting. 
Theories, Applications, and Methodologies (Gainesville, University of Florida, 25-27 January 2018).

Gonella, Francesco; Brocca, Giordano; Cristiano, Silvio; Khoury, Nicole; Salmistraro, Giovanna; Spagnolo, Sofia (forthcoming). "When Systemic Sustainability Is an Everyday Struggle: an Emergy-based Analysis of a Dog Shelter". Emergy Synthesis 10: Theory and Applications of the Emergy Methodology. Proceedings of the 10th Biennial Conference Emergy and Environmental Accounting. Theories, Applications, and Methodologies (Gainesville, University of Florida, 25-27 January 2018).

Hannon, Bruce; Costanza, Robert; Ulanowicz, Robert (1991). "A general Accounting Framework for Ecological Systems: a Functional Taxonomy for Connectivist Ecology". Theoretical Population Biology, 40(1), 78-104. Heikkurinen, Pasi; Lozanoska, Jana; Tosi, Pierre (2018). "Activities of degrowth and political change". Journal of Cleaner Production. DOI 10.1016/j.jclepro.2018.11.119.

Internazionale Situazionista (1992). La critica del linguaggio come linguaggio della critica. Torino: Nautilus.

Iovino, Serenella (2017). "Sedimenting Stories: Italo Calvino and the Extraordinary Strata of the Anthropocene". Neohelicon, 44(2), 315-30.

Krisis-Group (1999). Manifesto against Labour. URL http://www.krisis. org/1999/manifesto-against-labour/ (2018-12-04).

Lamb, Gary (1994). "Community supported agriculture". Threefold Review, 11, 39-43.

Latorre, Sara; Farrell, Katharine N.; Martínez-Alier, Joan (2015). “The Commodification of Nature and Socio-environmental Resistance in Ecuador: An Inventory of Accumulation by Dispossession Cases, 19802013". Ecological Economics, 116, 58-69.

Leonardi, Emanuele (2017). Lavoro Natura Valore. André Gorz tra marxismo e decrescita. Nocera Inferiore (SA): Orthotes.

Liegey, Vincent; Madelaine, Stéphanie; Ondet, Christophe; Veillot, AnneIdabelle (2013). Un projet de décroissance. Manifeste pour une Dotation Inconditionnelle d'Autonomie. Paris: Les éditions Utopia.

Martínez-Alier, Joan (1995). "The Environment as a Luxury Good or 'Too Poor to Be Green'?". Ecological economics, 13(1), 1-10.

Martínez-Alier, Joan (2014). "The Environmentalism of the Poor". Geoforum, 54, 239-41.

Odum, Howard Thomas (1983). Systems Ecology; an Introduction. New York: Wiley.

Odum, Howard Thomas (1994). Ecological and General Systems: an Introduction to Systems Ecology. Boulder (CO): University Press of Colorado.

Odum, Howard Thomas (1996). Environmental Accounting: Emergy and Environmental Decision Making. New York: Wiley. 
Odum, Howard Thomas (2007). Environment, Power, and Society for the Twenty-first Century: the Hierarchy of Energy. New York: Columbia University Press.

Scott Cato, Molly (2009). Green Economics. London: Earthscan.

Temper, Leah; Del Bene, Daniela; Martínez-Alier, Joan (2015). “Mapping the Frontiers and Front Lines of Global Environmental Justice: the EJAtlas". Journal of Political Ecology, 22(2).

Zinoni, Giancarlo (2000). "Riflessioni economologiche". Altronovecento, 2. URL ttp://wWw. fondazionemicheletti.eu/contents/documentazione/ archivio/Altronovecento/Arc. Altronovecento.02.06.pdf (2018-12-04). 



\author{
Through the Working Class \\ Ecology and Society Investigated Through the Lens of Labour \\ edited by Silvio Cristiano
}

\title{
Ecologies of Labour \\ An Environmental Humanities Approach
}

\author{
Stefania Barca \\ (Centro de Estudos Sociais, Universidade de Coimbra, Portugal)
}

\begin{abstract}
How do concepts of labour and working class relate to ecology? How can the Environmental Humanities make sense of the ways in which people experience nature through their work? Based on an ecofeminist approach, this chapter invites us to unpack the notion of labour and to see the multiple forms - not only production, but also reproduction and care - through which labour shapes and is shaped by the biophysical environment. The chapter is divided into two parts: the first introduces materialist ecofeminism as a perspective that allows us to rethink labour in ecological terms; the second proposes a three-way approach to investigating the ecologies of labour. The concluding section highlights the connection between the 'ecology of labour' approach and environmental justice.
\end{abstract}

Summary 1 Introduction. - 2 Rethinking Labour: a Materialist Ecofeminist Perspective. - 3 Investigating the Ecologies of Labour. - 4 Conclusions. Keeping the World Alive.

Keywords Ecology of labour. Working-class environmentalism. Environmental humanities. Ecofeminism. Environmental justice. Environmental studies. Political ecology.

We have mixed our labour with the earth, our forces with its forces too deeply to be able to draw back and separate either out. (Raymond Williams, "Ideas of Nature", 1980)

\section{Introduction}

Labour and working-class are concepts rarely found in the environmental humanities, and in environmental studies more in general. But does this mean that they are of no relevance to environmental scholarship? Or is this rather a reflection of the declining interest that they have suffered in the social sciences and humanities in the past three decades? Based on research in environmental history and political ecology that I have developed in the past decade, this essay intends to offer an alternative narrative of environmental change, one in which labour matters. Rather than a coherent theory, I aim to convey a sense of openness, imagination, and hope,

Culture del lavoro 8 ISSN [online] 2610-9379| ISSN [print] 2610-8852

DOI 10.30687/978-88-6969-296-3/002 | Submitted: 2018-07-20 | Accepted: 2018-08-29

ISBN [ebook] 978-88-6969-296-3 | ISBN [print] 978-88-6969-297-0

(c) 2018 | (1) Creative Commons Attribution 4.0 International Public License 
concerning the possibility of rethinking the relationship between ecology and labour in the age of climate change. Inspired by J.K. Gibson Graham, Stephen Resnick and Richard Wolff's edited volume Class and its Others, this essay will follow their invitation to 'opening up the field of class identity', and to building 'an antiessentialist language of class' (2000, 9-10). It will describe the condition of working-class as being in relations of not only production and exploitation, but also of reproduction, interdependence, and community with both human and non-human others in a shared biophysical environment. Such expanded understanding of working-class, I argue, would help us to discover new dimensions of that messy intersecting of the social and the biophysical that Serpil Opperman and Serenella Iovino (2016) consider the stuff of the environmental humanities.

The 'ecology of labour' is a materialist ecofeminist approach that calls attention towards labour as a key dimension of the material and cultural interchange between human and non-human nature. It tells us that class matters to ecology, i.e. the position one occupies in the social/sexual/colonial division of labour is a key element in determining how one is to experience this embeddedness with the ecological whole. It invites us to unpack the notion of labour itself and to see the multiple forms - not only production, but also reproduction and care - through which labour shapes and is shaped by the biophysical environment. It shows us how environmentalism, and ecological consciousness in general, is also a diversified experience, fundamentally mediated by labour and class. In short, the ecology of labour describes a world that is broader, more complex, and richer of experience of human/non-human nature relationships than the white/ middle-class understanding of it. This, I believe, would allow us to make an important step towards those "new modes of knowing and being", which Opperman and Iovino call for, with the aim to "enable environmentally just practices" $(2016,2)$.

The chapter is divided into two parts: the first introduces materialist ecofeminism as a perspective that allows us to rethink labour in ecological terms; the second proposes a three-way approach to investigating the ecologies of labour. The concluding section highlights the connection between the 'ecology of labour' approach and environmental justice.

\section{Rethinking Labour: a Materialist Ecofeminist Perspective}

A fundamental contribution to opening the semantic field of labour has come from the feminist critique of political economy. This has given a graphic representation of the economy in the form of an iceberg, showing how most of the work carried out in society is made invisible by conventional ways of understanding the economy (Gibson-Graham 2006). In the iceberg-economy model, waged work occupies only the floating tip, the 
part that is represented in politico-economic language. But what really matters is what happens below the sea level, i.e. the myriad other forms of informal, unpaid, domestic, reproductive, care, and community work that keep the tip afloat, for they make possible the value exchanges that happen in the formal economy. Those activities are labour too, say feminist political economists - in fact, they form the vast majority of the labour carried out in society. Making them visible is a first, fundamental step to redefine what counts as labour. Such reframing of labour is very relevant to the environmental humanities, insofar as it allows us to visit the terra incognita of working-class lives in all their diversity and interdependencies, and think about their possible relationships to ecology.

The reductive view of the economy developed by classical political economy - including much of Marxist political economy - has influenced common representations of the working class as well. Since the late Nineteenth century, working-class identity has been constructed (and later celebrated) as the collective of male heterosexual waged workers in manufacturing, mining, and farming. As the above-mentioned volume Class and Its Others (Gibson-Graham, Resnick, Wolff 2009) exemplifies, such reductive and homogeneous representation of the working class has generated many critiques and has been partially redressed by a number of studies; nevertheless, the general tendency has been that of abandoning class itself as a relevant arena of research, rather than reformulating it. What counts more for the scope of this essay, there is still much work to do in rethinking labour and the working class from an ecological perspective - and vice versa, understanding ecology as something which profoundly affects labour and working-class people (Singh 2013; Barca, Leonardi 2016; Battistoni 2017). The traditional representation of the working class as male blue-collar labour, in fact, has made invisible reproductive and unpaid labour, even when performed by members of the working-class community (i.e. family members of the male wage-worker), considering it irrelevant to class formation and identity. Moreover, it has rendered invisible and irrelevant the work performed by non-human animals: as co-workers in exploitative relations (e.g. in mining and farming activities), or as help in domestic and subsistence work (e.g. in dairy production, in transport, in cattle raising); and the autonomous work of non-human nature in general in performing life-supporting activities essential to humans, such as photosynthesis or biodegradation.

The diversity, and equal relevance, of all forms of work performed in societies in their interchange with the biophysical environment was illustrated by a pathbreaking theoretical framework developed by historian of science Carolyn Merchant in the late 1980s: the 'ecological revolution' framework (1987, 1989). This represented the first, and most complete, attempt at linking production and reproduction with ecology, showing how ecological crises, and eventually radical environmental change (or 
'ecological revolution'), arise from contradictions between modes of production and social reproduction, on one side, and ecology and biological reproduction on the other. Adopting a Marxist approach, Merchant distinguished between two types of human production: for use-value or subsistence, and for exchange value or the market; she then defined human reproduction as the biological and social process through which humans are born, nurtured, socialized, and governed, i.e. the practices through which "sexual relations are legitimated, population sizes and family relationships are maintained, and property and inheritance practices are reinforced" (Merchant 1987, 270). Human production and reproduction, she noted, have been historically divided along gender lines, generating the sexual division of labour. Under capitalism, the division of labour between the sexes has meant that men bear the responsibility for and dominate the production of exchange commodities, while women bear responsibility for reproducing the workforce and social relations. Women's responsibility for reproduction includes both the biological reproduction of the species (intergenerational reproduction) and the intragenerational reproduction of the workforce through unpaid labour in the home, including the reproduction of social relations-socialization. While in subsistence-oriented economies production and reproduction are united in the maintenance of the local community, she explained, with the advent of capitalism production and reproduction separated into two different spheres, with the latter subordinated to the former.

A third aspect of social interchange with the environment, in Merchant's model, was consciousness, i.e. the collective ways of understanding and representing nature. These substantiate in mythology, cosmology, science, religion, philosophy, language, art, literature and folklore (rituals, festivals, songs, and myths). Not all representations of nature have equal power, of course: each mode of production requires certain ideas of nature to predominate in order to configure dominant forms of ecological consciousness. Translated into action through ethics, law, morals, and taboos, these specific forms of ecological consciousness legitimate and normalize human behaviour toward non-human nature.

According to Merchant, ecological revolutions could be understood as a complete reconfiguring of the relationships between the four spheres of production, reproduction, ecology, and consciousness. Applying her model to the history of New England, Merchant identified two ecological revolutions related to the introduction of the capitalist/patriarchal mode of production in North America: the colonial (Seventeenth century) and the industrial (Nineteenth century). Each had been premised on and shaped by a fundamental reconfiguration of both women's work in society, and of scientific-philosophical understandings of nature (or ecological consciousness). Merchant's 'revolution', clearly distinct from the concept of sizing power, was a complex concept integrating the bio-physical world with the 
social and the cultural: her subsequent work made clear that the next ecological revolution called for new forms of ecological conscientiousness and mobilization in the most complete and thorough sense of the term i.e. involving the self, intended as the relationship between genders and between human and non-human nature, what she later called the "ethic of partnership", or "earthcare" (Merchant 1989; 1995).

The materialist ecofeminist approach - of which Carolyn Merchant is a widely recognized theorist - is consistent with and partly built upon feminist political economy. Materialist ecofeminism changes our understanding of the relationship between labour and ecology. First, it forces us to pay attention to productive and reproductive labour, and to mechanisms of social subordination regarding both, as the fundamental dimension of society's interchange with non-human nature. Second, it calls into question gender oppression (i.e. patriarchy) as a key mechanism through which environmental crises are produced, insofar as it serves the scope of subordinating reproduction and subsistence activities to production and exchange. Third, it calls attention towards particular forms of consciousness - e.g. capitalist political economy coupled with western science - as what legitimizes and governs ecological crises. Through these mechanisms, 'the economy' becomes redefined as a sphere of production and exchange whose unlimited expansion is a primary and incontestable social end. As ecofeminist authors have argued (e.g. Mies, Shiva 1993), all social progress, including women's emancipation, becomes dependent on this monstrous deity called 'the economy', whose feeding requires sacrifices. In short: the materialist ecofeminist perspective allows to radically and fully expose the production/reproduction dualism on which industrial societies are based as a root cause of the global ecological crisis.

\section{Investigating the Ecologies of Labour}

Investigating the ecologies of labour requires to start from the assumption that labour and working-class ecologies are primarily sites of environmental injustice. Environmental injustice, as I have argued elsewhere (Barca 2014a), is a dual process, made of both material and symbolic violence. The former consists in producing environmental costs that end up concentrating in a number of sacrifice areas, disproportionately affecting the disposable bodies (human and non-human) that inhabit them. The latter consists in erasing the collective memory of material environmental violence: hiding evidence, silencing voices, or simply looking the other way, in order to ignore those stories that would put into question consolidated regimes of truth. Investigating the ecologies of labour is thus an important way in which the environmental humanities can counteract the symbolic violence of environmental injustice, by collecting and narrating the al- 
ternate stories of environmental degradation and resistance that affect working-class people and the places where they live work and play. The environmental humanities can give an invaluable contribution to such an investigation, by interrogating all those sources - texts, oral histories, artefacts, films, photographs and paintings, and more - that embody the organic relationship between work and (human and non-human) nature in their multiple and mutually constitutive meanings.

In my article "Laboring the Earth" (Barca 2014b), I have suggested three, interconnected levels of investigation on the ecologies of labour: the labourscape, the working-class community, and labour environmentalism. Taken together, these three analytical levels illuminate the structural, contingent and contradictory conditions in which labour and working-class people experience 'nature' (intended as the biophysical environment) and develop own forms of environmental mobilization.

The first level of analysis is that of the labourscape, i.e. the study of how different landscapes physically incorporate different forms of work in different labour regimes, an idea originally formulated by the British literary critic and socialist intellectual Raymond Williams, a seminal inspiration for scholars in ecocriticism. Based on studies in environmental history and human geography, as well as on visual sources (e.g. photographs, video documentaries) we could investigate how people shape and are shaped by the labourscapes of different commodities in farming, extraction, transport, processing, and waste disposal activities. But labourscapes are also produced via the non-commodified, unwaged labour of environmental care, that takes place in conservation, restoration, maintenance, regeneration and nurturing activities, mostly in the commons. This is what feminist political ecologists have called the "forces of reproduction", or else "metaindustrial work", i.e. "a subliminal 'other' sphere of labor and value", that produced by the "peasants, mothers, fishers and gatherers working with natural thermodynamic processes who meet everyday needs for the majority of people on earth" (Salleh 2010, 205). Necessary to industrial production and exchange value, these workers typically inhabit "the margins of capitalism - domestic and geographic peripheries", and thus they are "unspoken, as if 'nowhere' in the world-system" (Salleh 2012, 141). Naming them "meta-industrial labour", while noting that they form the majority of the world's working class, is for Salleh an important way to make their work visible, and to value it as 'rift-healing', i.e. contrasting the degradation of bodies and ecosystems put in motion by industrial production.

A second analytical level where we can research the ecology of labour is that of the working-class community. My research on the history of industrial hazards in post-war Italy, conducted along the past ten years, with particular attention to three sites of industrial disaster (Barca 2012, 2014c; Barca, Leonardi 2016) has led me to develop an analytical framework that I call, together with Emanuele Leonardi, the Working-Class Com- 
munity Ecology (WCCE). The framework starts from the assumption that industrial workers and their communities typically embody the ecological contradictions of industrialism/capitalism, and thus develop specific forms of ecological consciousness. The WCCE is centred on particular workplaces and their connection with workers' bodies and those of other community members via the biophysical environment. This relationship, however, is mediated by multiple positionalities: not only occupation, but also skin colour, gender, age, ability, and others. These positionalities, in turn, intersect with the different forms of work that sustain and reproduce the working-class community in and beyond the workplace itself, including domestic and social reproduction work.

What characterizes working-class community ecologies, however, is their quasi-total economic dependency upon some external income generator, such as industrial manufacturers, mining or energy companies, agri-business, retail companies. Economic dependency from industrial work is correlated with a marked devaluation of all meta-industrial work. This social devaluation of reproduction work generates extreme vulnerability to the jobs blackmail - i.e. the corporate practice of threatening industrial workers with a choice between employment and environmental/ public health (Kazis, Grossman 1982) - thus strongly impairing people's ability to react to the depleting and degrading effects of metabolic rift on their territories. In other words: in the industrial phase of ecological revolution, the patriarchal gender order has given men the role of breadwinners, making them bargain for wages that heavily discount their health and safety, or accept job blackmails that compromise the health and safety of entire communities and their territories; it has assigned women the role of reproducers and caregivers, but also of economically marginal and/ or dependent subjects, with little or no bargaining and decision-making power in society.

Recognizing that environmental injustice is not a natural fact but a historical product, rooted in the sexual and racial division of labour, can lead working-class communities to overcoming the division between labour and environmental organizing, and to struggle for a radical transformation of 'the economy', based on principles of mutual interdependency between production, reproduction, and ecology. In other words, ecological consciousness as developed in working-class communities can originate a distinctive type of environmentalism, a 'working-class environmentalism'.

This takes us to the third analytical level of the ecologies of labour: labour environmentalism, or the environmental agency of labour organizations, which reflects the particular position of industrial workers as mediators of social metabolism. The experience of labour environmentalism in three countries (Italy, Brazil and the US) in the second half of the Twentieth century, shows how political consciousness of the environmental and public health costs of industrialization had been formed in the workplace, 
being physically embodied by working people in their daily interaction with the hazards of production. This in turn invited to a reconsideration of the active role that workers in the post-war era have played in shaping modern ecological consciousness and regulation, both within and outside (even, sometimes, against) their organizations: promoting a number of important legislative reforms, struggling for the improvement of work environments, demanding the extension of workplace health and safety regulations to society as a whole. Such method of struggle in labour environmentalism had been made possible, in different historical moments in the three countries, by the political alliance between trade-unions and environmental organizations - an alliance that was then put in crisis by changes in the respective political and economic scenarios (Barca 2012b).

Labour environmentalism has received attention from a number of scholars in sociology, political science and international relations, thus it is probably the most well-known of the three dimensions of the ecologies of labour. From an EH perspective, it is important to keep in mind that a major trend of the neoliberal era has been the convergence between labour and Ecological Modernization, that has generated what I have called labour's eco-modernism, and its contemporary divergence from anti-capitalist ecological movements and Environmental Justice. Adopting a material eco-feminist perspective on labour and working-class agency, I argue that the crux of the matter for a critique of labour's political ecology consists in broadening the semantic sphere of 'labour' towards including both industrial and meta-industrial work in their dialectical historical relationship. This, I argue, would allow us to broaden the scope of labour environmentalism by developing a decolonization of labour, both as concept and praxis, and rendering visible its potentialities as an agent of ecological revolution (Barca 2017).

\section{Conclusions. Keeping the World Alive}

This chapter has shown how a materialist ecofeminist perspective can help us not only to reconceptualize labour, but also environmentalism. Just as a restricted conceptualization of the economy has made invisible much work and its importance in society, so a restricted conceptualization of environmentalism has made invisible much environmental consciousness and action that takes place in society. Like the economy, so environmentalism can be seen as an iceberg: the visible part is formed of the white well-educated middle class that most environmental literature celebrates as its heroine. The larger part underneath, however, is made of low-income and racialized people such as working-class women in urban peripheries, indigenous communities, peasants, fishers and workers in the dirtiest jobs, whose bodies and territories are on the frontline of a global environmen- 
tal justice struggle against the hazards of production. These are to be considered working-class people in the extended sense of the term, i.e. people who make a living out of their metabolic interchange with nature, under conditions of social subordination and dispossession, and who fight the ecological contradictions of capitalism not only because they make altruistic choices on behalf of future generations and non-humans, or because they believe in the integrity of human-nature relationship, but also because they have a direct interest in defending nature and the integrity of their living environments and means of subsistence. As ecofeminist and environmental justice scholars have been documenting for decades, it is primarily working-class people - in this broadest sense - that get sick when pollution levels become too high, that starve when there is no more fish in the river, that get to migrate when there are no more trees in the forest, or sea levels rise too high, or in the wake of catastrophic climate events (Mies, Shiva 1993; Martínez Alier 2003; Salleh 2009; Garvey 2011). Taken together, these different sections of the iceberg of environmentalism may be seen as the largest collective effort at keeping the world alive.

Probably the most relevant contribution that the ecology of labour can offer to the environmental humanities is this awareness of the material and symbolic pluriversality (Escobar 2018) of environmentalism, intended as people's embeddedness with and affection for non-human nature. It is here, perhaps, that the ideological apparatus of modern environmental politics, based on cartesian dualisms between material and immaterial values, could finally fall apart, and new possibilities could open up for thinking sustainability with (rather than against) labour.

\section{Bibliography}

Barca, Stefania (2012a). "Bread and Poison. The Story of Labor Environmentalism in Italy, 1968-1998". Sellers, Christopher; Melling, Joseph (eds.), Dangerous Trade. Histories of Industrial Hazards across a Globalizing World. Philadelphia: Temple University Press.

Barca, Stefania (2012b). "On working-class environmentalism. A historical and transnational overview". Interface. A journal for and about Social Movements, 4(2), 61-80.

Barca, Stefania (2014a). "Telling the Right Story: Environmental Violence and Liberation Narratives". Environment and History, 20(1), 535-46.

Barca, Stefania (2014b). "Laboring the Earth. Transnational reflections on the environmental history of work". Environmental History, 19(1), 3-27.

Barca, Stefania (2014c). "Work, Bodies, Militancy: the 'Class ecology' Debate in 1970s Italy". Boudia, Soraya; Jas, Nathalie (eds.), Powerless Science? Science and Politics in a Toxic World. New York: Berghahn Books. 
Barca, Stefania (2017). "Labour and the Ecological Crisis: The Eco-modernist Dilemma in Western Marxism(s) (1970s-2000s)". Geoforum (in press). URL http://dx.doi.org/10.1016/j.geoforum.2017.07.011.

Barca, Stefania; Leonardi, Emanuele (2016). "Working-class Communities and Ecology. Reframing Environmental Justice around the Ilva Steel Plant in Taranto, Apulia (Italy)". Shaw, Mae; Mayo, Marjorie (eds), Class and Community Development. Bristol; Chicago: Policy Press, 59-76.

Battistoni, Alyssa (2017). "Bringing in the Work of Nature: From Natural Capital to Hybrid Labor”. Political Theory, 45(1), 5-31.

Escobar, Arturo (2018). Designs for the Pluriverse: Radical Interdependence, Autonomy, and the Making of Worlds. Durham: Duke University Press.

Garvey, Michelle (2011). “Toward 'Global Feminist Environmental Justice'”. Feminist Formations, 23(2), 16-223.

Gibson-Graham, Julie-Katherine (2006). A Postcapitalist Politics. Minneapolis: University of Minnesota Press.

Gibson-Graham, Julie-Katherine; Resnick, Stephen R.; Wolff, Richard D. (eds.) (2000). Class and Its Others. Minneapolis: University of Minnesota Press.

Kazis, Richard; Grossman, Richard L. (1982). Fear at Work: Job Blackmail, Labor and the Environment. New York: Pilgrim.

Martínez Alier, Joan (2003). The Environmentalism of the Poor. A study in Ecological Conflicts and Valuation. Cheltenham: Eduard Elgar.

Merchant, Carolyn (1987). "The theoretical structure of ecological revolutions". Environmental Review, 11(4), 265-74.

Merchant, Carolyn (1989). Ecological Revolutions. Nature, Gender, and Science in New England. Chapel Hill: University of North Carolina Press.

Merchant, Carolyn (1995). Earthcare. Women and the Environment. London: Routledge.

Mies, Maria; Shiva, Vandana (1993). Ecofeminism. London: Zed Books.

Oppermann, Serpil; Iovino, Serenella (eds.) (2016). environmental humanities. Voices from the Anthropocene, London: Rowman \& Littlefield.

Salleh, Ariel (2010). “From Metabolic Rift to Metabolic Value”. Organization \& Environment, 23, 205-19.

Salleh, Ariel (2012). “'Green Economy” or Green Utopia: the Salience of Reproductive Labor Post-Rio+20”. Journal of World-System Research, 18(2), 138-45.

Salleh, Ariel (ed.) (2009). Eco-Sufficiency and Global Justice: Women Write Political Ecology. London: Pluto Press; Spinifex Press.

Singh, Neera (2013). "The affective labor of growing forests and the becoming of environmental subjects: Rethinking environmentality in Odisha, India”. Geoforum, 47, 189-98. 


\author{
Through the Working Class \\ Ecology and Society Investigated Through the Lens of Labour \\ edited by Silvio Cristiano
}

\title{
Subaltern Environmentalism in Can Sant Joan, Catalonia
}

\author{
Sergio Ruiz Cayuela \\ (Välkommen till KTH, Stockholm, Sveriges)
}

\begin{abstract}
In this piece I analyse the ways in which marginalized communities respond to intentional environmental discrimination by political and economic elites. In order to do so, I briefly reflect on the terms subalternity and environmentalism; and I characterize subaltern environmentalism in terms of political orientation, types of communities involved, conception of the environment and issues of concern, and positionality. In order to test the previously developed blueprint I use the case study of Can Sant Joan (Catalonia), a working-class migrant neighbourhood where a movement against waste incineration emerged when the Asland cement plant got a permission to use refuse derived fuels in 2006.
\end{abstract}

Summary 1 Introduction. - 2 About Subaltern Environmentalism. - 3 Methodology. - 4 The Struggle against Waste Incineration in Can Sant Joan. - 4.1 The Community. - 4.2. The Struggle 4.3 Subalternity as the Main Feature. - 5 Conclusion.

Keywords Subaltern. Environmentalism. Waste. Incineration.

\section{Introduction}

Structural inequalities that sustain the domination of economic elites often simultaneously result in environmental discrimination of subaltern communities (Ageyman 2005). The Cerrell Report, written in 1984 by the Los Angeles consulting firm Cerrell Associates, at the request of the California Waste Management Board, sought to define the type of communities that were less likely to resist siting of locally unwanted land use (LULU). The study, that is purportedly believed to have been circulated throughout regulatory agencies and industries across the USA, proposed different political criteria for the selection of Waste-to-Energy sites and indicated that placing was not based on scientific criteria (Energy Justice Network s.d.). Consequently, most of the communities affected by nearby LULUs in the USA have something in common: they are, in some way, subaltern communities experiencing intentional discrimination (Bullard 2008). These highly polluted residential/industrial areas are called 'sacrifice zones', a

Culture del lavoro 8 ISSN [online] 2610-9379| ISSN [print] 2610-8852

DOI 10.30687/978-88-6969-296-3/003 | Submitted: 2018-07-20 | Accepted: 2018-08-31

ISBN [ebook] 978-88-6969-296-3 | ISBN [print] 978-88-6969-297-0

(c) 2018 | (1) Creative Commons Attribution 4.0 International Public License 
term used to designate dangerously radioactive areas resulting from the nuclear race that took place during the Cold War (Lerner 2010). Sacrifice zones, though, are not an exclusive phenomenon of the USA: subaltern communities inhabit these hot spots of pollution all around the globe (Armiero, D'Alisa 2012). When they realize - commonly by chance - the hazards they are being intentionally exposed to, subaltern communities usually undergo a similar process of awakening that culminates in subaltern environmental movements (Lerner 2010). My goal in this chapter is to analyze the main features of subaltern environmentalism. To this end, I begin by briefly reflecting on the terms 'subalternity' and 'environmentalism'. I characterize subaltern environmentalism in terms of political orientation, types of communities involved, positionality, conception of the environment and issues of concern. I then move on to introduce the Can Sant Joan community and their struggle against waste incineration in the Asland cement plant. Finally, I discuss whether the local anti-incineration movement is a case of subaltern environmentalism according to the previously developed blueprint.

\section{About subaltern environmentalism}

Subalternity is a controversial term that has been used and appropriated by many authors over the years. Gramsci - who inflicted the military concept of subaltern with a new meaning in the early Twentieth century (Green 2002) - considers that the subaltern are all the non-elite groups, those oppressed by the relations of hegemony within society. For him, the only way of leaving subalternity is by reversing the existing relationship of domination-subordination. Gramsci does not consider the subaltern groups as equivalent. Instead, he differentiates them by their level of political organization in their way to achieve complete autonomy, an ideal state contrasting subalternity in which a group is not subject to domination (Gramsci 2011). With the rise of subaltern studies in the 1980s, some authors embraced a relatively close vision to Gramscian subalternity (see Guha 1982), whereas others diverged. Gayatri Spivak is the most relevant author of the latter current. For her, the subaltern encompass only those so displaced that they lack any kind of political organization and representation. Thus, she argues, once they revert this situation and achieve visibility they are no more subaltern (Spivak 1988). Pulido's view on subalternity is in line with Gramsci. She defines subaltern struggles as "counterhegemonic, [...] exist[ing] in opposition to prevailing powers" $(1996,4)$. She also agrees with Gramsci on the impossibility of determining a single cause of marginalization of subaltern groups. Instead, they both identify an ensemble of political, social, cultural and economic relations, interdependent among them, as the multiple cause. Both authors also 
concur in arguing that domination-subordination relationships are perpetuated through structural inequalities - based on class, race or culture among other factors. Such structural inequalities are in turn legitimized by the hegemony of the dominant group within civil society.

Environmentalism is a very disparate movement that covers different forms of activism (Armiero, Sedrez 2014). Historically, it has been thought to be a concern of the elites, or in the words of Nash (2014) a "full stomach" phenomenon. He foresaw western environmental activism as a luxury of the middle and high classes, almost like a hobby for those whose material needs were covered. Nevertheless, more comprehensive historical reviews have shown that Nash's conception of environmentalism was very narrow. Martínez Alier (2003) provides a more exhaustive classification of environmental currents. He separates environmentalism in three groups, focused on: wilderness and preservation of endangered species; sustainable management of resources through technological advance; and livelihood conflicts that oppose structural inequalities, which he calls "environmentalism of the poor" (2013). By showing cases of the latter group as far back as the 1880s, Martínez Alier challenges the classical vision of American environmentalism represented by Nash, uncovering its US-centric bias. Arguably, though, Martinez Alier's classification is not completely compelling; "environmentalism of the poor" denotes economic status as a main form of domination, leaving out of the spectrum other forms of alternative environmentalism. In line with Pulido and Gramsci, I argue that as well as being due to economic status, the causes of subordination of a group can also be political, social and/or cultural. Thus, I believe that the term subaltern environmentalism encompasses different forms of alternative environmentalism and helps us to achieve a more accurate conceptualization. Moreover, talking about subaltern environmentalism seems very appropriate in the current climate of escalating inequalities. Most of the environmental burdens placed on vulnerable communities respond to social and environmental subordination strategies used by political economic elites in order to perpetuate their ruling position (Egan 2002).

Thereupon, I will describe the main features of subaltern environmentalism that in many cases are shared with other forms of alternative environmentalism. First, subaltern environmentalism is charged with political claims of social justice and equity. Its claims are as social as they are environmental. Moreover, they have a specific political content that is usually related with the radical left. In subaltern environmentalism, social and environmental subordination is seen as a tool of political economic elites, in order to reinforce and perpetuate their ruling position (Egan 2002). Communities involved in these struggles perceive unequal power relations as the main threat to their environments and livelihoods; they, thus, seek to challenge the hegemony of the dominant group. A second trait of subaltern environmentalism is the type of communities involved. Subaltern 
environmental struggles usually involve people that are already defined as a community or social group of some kind. Nevertheless, communities are influenced by the struggles to such an extent that their original communal identity is often reshaped through the development of a subaltern consciousness (Pulido 1996). Third, subaltern environmentalism embraces a broad conception of the environment, that constitutes the places where subaltern communities live out their everyday lives. For subaltern communities, the distinction between anthropocentrism and biocentrism, which has classically informed mainstream environmentalism, does not make sense. Rather, they perceive the environment as their source of livelihood and, thus, are willing to protect it (Guha 1989). In subaltern environmentalism, the boundaries of the environment are expanded, it becomes everything that surrounds communities (Armiero, D'Alisa 2012; Novotny 2000), including urban spaces. Finally, positionality is arguably the most defining feature of subaltern environmentalism. For the involved communities, environmental struggles are mainly materialist. Their livelihoods depend, to a greater or lesser extent, on the outcome of the struggles. As Pulido puts it, their "position in the socioeconomic structure, in turn, frame their struggles differently" $(1996,25)$. Communities involved in these struggles are subordinate to the hegemonic class, that has classically prioritized economic productivity over their well-being. More recently, increasingly rapid environmental degradation has stimulated the hegemonic class to adopt green economy strategies, which still seek to reinforce its dominant position (Goodman, Salleh 2013). Thus, subaltern communities embrace a counter-hegemonic position and live their environmental struggles in first person.

Table 1. Principal features of subaltern environmentalism

\begin{tabular}{ll}
\hline Principal features of subaltern environmentalism \\
\hline Political orientation & $\begin{array}{l}\text { Seeks social justice and equity, challenges the dominant group, often } \\
\text { aligned with radical left-wing politics. }\end{array}$ \\
\hline Communities involved & $\begin{array}{l}\text { Direct personal connection to the issues of concern. Existing communal } \\
\text { identity that is reshaped in the struggle. }\end{array}$ \\
\hline $\begin{array}{l}\text { Conception } \\
\text { of environment } \\
\text { and issues of concern }\end{array}$ & $\begin{array}{l}\text { The environment is everything that surrounds communities, including } \\
\text { urban environment. Material conflicts directly related to sources of } \\
\text { livelihood for vulnerable communities. }\end{array}$ \\
\hline Positionality & $\begin{array}{l}\text { Counter-hegemonic conflicts embraced by communities subordinate } \\
\text { to political economic elites. Struggles lived in first person: their lives, } \\
\text { their land. }\end{array}$ \\
\hline
\end{tabular}




\section{Methodology}

Fieldwork for this research was conducted during February 2017, but before arriving to the field I exchanged extensive correspondence with two key informants: J.L.C., president of the neighbourhood association of Can Sant Joan and member of the local platform against incineration (PAMiR); and N.V.L., member of Ecologistes en Acció and former worker of the local Montcada i Reixac (MiR) municipality in the environment area for 20 years. The main data source for this research consisted in a sample of 21 semistandardized interviews. For the selection of the interviewees I used both snowball (Berg, Lune 2012) and judgmental (Hagan 2006) sampling, building upon the information obtained from the key informants. Through this broad sampling approach, I tried to accurately represent all the parties in the ongoing local struggle against refuse-derived fuels (RDF) use, including members of the PAMiR, the neighbourhood association, the local women's and youth groups, local politicians and municipal employees, managers of the cement plant, scientists, practitioners, and members of regional and global environmental groups. The interviews conducted have only been used as data under the informed consent of the interviewees. There was only one interview where I could not obtain a signed informed consent form: the interview with the cement plant managers. Thus, none of the information that they provided during the interview have been directly used in this research study. Nevertheless, I considered licit to use information from my visit to the cement plant in form of direct observations as long as it did not make reference to the words of the interviewees.

I have decided to corroborate and augment the evidence obtained through interviews with several other data sources, in what is commonly known as a triangulation process (Yin 2003). These include: a) documentation: air quality reports produced by the community, scientific studies conducted by environmental organizations, peer reviewed scientific papers, and legal documents; b) archival records: municipal contracts, historical correspondence involving the municipality, the complete collection of the Can Sant Joan monthly magazine Hoja Informativa (1966-2017), organisational budgets, and economic and demographic data; c) direct observations: I kept record of my observations in the field by taking notes and pictures (without compromising privacy rights); d) physical artifacts: graffiti and other artistic forms, and a collection of dust samples kept in jars collected at balconies and homes by community members to make visible their exposure to pollution. I have only used documents and archival records whenever they were public or I could obtain permission from the copyright holders. 


\section{The Struggle against Waste Incineration in Can Sant Joan}

\subsection{The Community}

The neighbourhood of Can Sant Joan is part of the municipality of Montcada i Reixac (MiR), in the outskirts of Barcelona. It was born as a place where the unskilled workers from the railway line and the Asland cement plant could settle down at the beginning of the Twentieth century. The mass migration from rural to industrial areas that took place in Spain during the 1950s and 1960s dramatically transformed the neighbourhood. During this period, it underwent a process of spontaneous urban development (Epstein 1973). It was in this context that the Can Sant Joan neighbourhood association was created. Its goal was to improve the living conditions in the neighbourhood and foster conviviality among the community. "Since I arrived to Can Sant Joan 44 years ago the neighbourhood has changed a lot, we have achieved some major improvements" (interview 1). During the first years of the Twenty-first century Can Sant Joan saw the arrival of a new wave of migrants from disparate cultural backgrounds that, thus far, have not been integrated with the old-time residents. Can Sant Joan is nowadays a working-class, poor, migrant neighbourhood. The positionality of the neighbourhood, compared to the city and the province of Barcelona, can be summarized in the following terms: very poor economic and educational levels, very low price of real estate properties, appropriate number of cultural spaces and poor level of urban services. Notably, though, it is important to keep in mind that the latter two were achieved through popular mobilization. Moreover, public and private institutions very rarely led the way in improving life in the neighbourhood. If we add to the analysis the deeply entrenched working-class consciousness among the community members (interviews 1, 2, 4-11, 13-17, 19, 20), there is no doubt that Can Sant Joan can be considered a subaltern community. Its existence is opposed to two prevailing powers of different scale: the center of MiR and the city of Barcelona. It is worth noting the influence that scale has in this analysis. If we set the boundaries at a municipality level the center of MiR is the dominant community, whereas if we set them at a regional level MiR becomes subordinate to the city of Barcelona. Thus, the same territory simultaneously plays two roles, as ruling and subordinate, depending on the scale. Nevertheless, although identifying geographical areas with specific social groups might work in small and unified communities, it requires further study of the social fabric.

Judging by the opinion of the neighbours and local politicians as well as economic, educational and real estate indicators, there are many communities in the surrounding neighbourhoods (both in MiR and in the Nou Bari ris district, Barcelona) that are in a similar situation and could also theree fore be considered subaltern. Can Sant Joan, thus, is not a unique case. 
Indeed, the area of El Vallès (of which MiR is part) is commonly referred to as the industrial park of Barcelona, because of the high concentration of industrial areas and working-class communities (interviews 1, 2, 4, 14, 15, $19,20)$. Yet, there are some characteristics that make Can Sant Joan stand out as a special case. The most important one is the sense of attachment to a community that reigns in the neighbourhood. At the core of this community is the neighbourhood association. This communal identity has been shaped by decades of struggles for improving life in the neighbourhood in different ways: "this has always been a community were people have organized in order to fight, there is a special atmosphere in the neighbourhood that makes us feel from Can Sant Joan" (interview 1). Some 4,200 people in Can Sant Joan - out of the total 5,500 inhabitants - are affiliated to the neighbourhood association, which was the first one created in Catalonia. In 2015 and 2017 the association gained national recognition when received the prize to the most socially relevant neighbourhood association by the Confederation of Neighbourhood Associations of Catalonia (CONFAVC, Catalan abbreviation) (interview 1). Some of the individuals holding positions of responsibility in the association have a political past linked to trade unions and communist or anarchist groups. A few of them were even involved in armed antifascist groups during Franco's dictatorship. Their background has permeated the neighbourhood association, which has become a very active political tool of the working-class neighbourhood in their quest for social and environmental justice. In fact, the association has had many open conflicts with the MiR municipality whenever their claims have been obviated and their protests violently suffocated (interviews 1, 2, 4-11, 13-17, 19, 20). "In one of the first protests against the Asland we blocked the main highway. Suddenly, we saw the riot police in full gear coming after us!" (interview 2). Yet, the neighbourhood association is not only a political tool, but an open ground for integration in the community. The local parish, that has since the 1960s been directed by an openly communist priest, has also played a very relevant role in fostering conviviality in the neighbourhood. In fact, the neighbourhood association and the parish have worked side by side to pioneer many self-organized activities that have contributed to build bonds and avoid conflicts among the neighbours while improving the quality of life in the neighbourhood (interview 14). Can Sant Joan is, thus, more politically organized than the rest of surrounding subaltern communities. As such, it arguably stands at a higher level in the Gramscian ladder towards autonomy and towards overcoming subalternity. As N.V.L. (interview 13), member of Ecologistes en Acció and former worker of the MiR municipality in the environment area during 20 years, puts it: "I believe that [the neighbours of Can Sant Joan] were destined to be subalterns, but they have rejected their fate. They fought back and freed themselves from marginality". 


\subsection{The Struggle}

The community of Can Sant Joan has a long story of engagement in different struggles for improving livelihood conditions in the neighbourhood. Reportedly, one of the most significant is the dispute against pollution from the Asland cement plant. This particular conflict has gone through different stages since the 1960s. What, some decades ago, was a moderate discontentment during episodes of heavy pollution has been gradually replaced by a general opposition to the very existence of the cement plant. Implementation of automated processes in the Asland, that reduced its labor force from several hundred to barely 50 workers nowadays - none of whom are from the neighbourhood - has had a crucial role in altering public opinion. "The cement plant used to employ many people from the neighbourhood, but today the story is very different. This has tipped the scale toward major opposition" (interview 15). The struggle reached a peak of intensity in 2006, when the cement plant received permission to use refuse-derived fuels, or in other words, to incinerate waste. At that moment, a movement arose in Can Sant Joan and a platform against incineration (named PAMiR for its Catalan abbreviation) was created in 2007, at the heart of which is the neighbourhood association. As is often the case, the movement went through a high intensity phase during its first 18 months, before then being consolidated in a low intensity phase that still lasts. The struggle has enhanced the subaltern consciousness of the community that, by bridging alliances with other communities involved in similar conflicts, has embraced a complex neighbourhood-detached subaltern identity. In other words, Can Sant Joan neighbours feel now part of a wider group of subaltern communities that are aware of being structurally discriminated by political economic elites. Incrementally, the conflict has become a quest for autonomy and social justice as much as a matter of environmental health. It is because of this that I argue that the movement against incineration in Can Sant Joan is a perfect example of subaltern environmentalism. Since the struggle lowered its intensity and was stabilized in 2008, the PAMiR and the community of Can Sant Joan have been all but still. The resistance has concentrated efforts in timely but significant actions, that can be organized in four interdependent groups: protest actions, legal actions, street science, and coalition building.

Very diverse and imaginative protest actions have been carried out by the PAMiR in the last decade. They have included demonstrations with up to 2,000 people, sabotaging of public events in which local authorities took part, themed Carnivals, shooting of the movie Arcángeles in which pollution from the Asland cement plant originates a zombie epidemic, organizing the Estem Cremats (We Are Burned) music festival, and gaining public support by celebrities in media appearances. Some of these protest actions have created great controversy due to direct confrontation with workers 
from the Asland and other cement plants. As a Can Sant Joan neighbour puts it "several times LafargeHolcim [current owner of the cement plant] has fleeted buses from Sagunt and other Spanish towns in order to bring workers and threaten the neighbours that were demonstrating" (interview $20)$. When it comes to legal actions, the PAMiR has started two lawsuits against the Asland: one on irregularities in the environmental impact assessment related to RDF use in the cement plant that led to a moratorium in 2008; and another - still ongoing - on exceeding permissible noise levels in the neighbourhood. Several crowdfunding campaigns have been organized to defray the legal costs. Community members have made use of street science (Corburn 2005) to oppose Asland's narrative about traffic being the almost exclusive source of pollution in the neighbourhood. PAMiR activists have taken part in the co-production of knowledge with scientists and practitioners. Moreover, dissemination talks chaired by renowned researchers have been organized in and beyond the neighbourhood, in order to raise awareness and increase the critical mass of the movement. Local activists have also engaged in joint activities with universities at undergraduate and postgraduate levels. The PAMiR has also put a lot of effort in building coalitions. In fact, the platform is founding member of the Catalan and Spanish networks against waste incineration in cement plants, which hold regular meetings. As reflected in the fact that the 2 nd international meeting against waste incineration, organized by the Global Alliance for Incineration Alternatives (commonly known as GAIA), was held in the neighbourhood in 2015, Can Sant Joan has also been able to find allies at an international level.

Even if the local resistance to waste incineration in Can Sant Joan seems to revolve around the PAMiR, the real operational core is still the neighbourhood association. In fact, the PAMiR is not legally constituted as an association. Rather, for instance, the legal actions are carried out in the name of the neighbourhood association (interview 1). Whilst there is a divergence of opinions about how many people participate in the movement against waste incineration in Can Sant Joan, there is a consensus that its structure is organized in rings of engagement. At the core of the movement there are small groups with higher level of engagement, that are at the same time included in wider groups with a lower engagement in the struggle. Interviewees agreed about the main figures of the movement being, namely at the time of writing, J.L.C. (president of the neighbourhood association) and M.G. (member of the management board). They belong to a group averaging 8 people, most of whom are from the management board of the neighbourhood association, that are very active in the movement against the Asland and that carry out most of the tasks. The next ring is comprised by a group of 20-25 people who are involved in the decision making of the PAMiR and who attend most of the meetings and events. They do so even when this involves travelling out the neighbourhood for 
meeting other communities or external organizations. "We have recently been in Sevilla, in November [...] and we have recently been in Italy fighting the Asland as well. We also held a huge meeting here in Can Sant Joan, and people from all around the world came" (interview 5). When a general assembly of the PAMiR is called, or local events organized, the group expands up to 80 to 100 people. When demonstrations or other big events are held, the social mass can reach from 200-300 up to 2,000 people. Among those actively involved in the movement, there is a majority of white Spanish aged males who have lived in the neighbourhood for decades. The PAMiR has identified this trend and is currently trying to reverse it. In 2016, for example, the neighbourhood association started a women's group and in 2017 a youth group. Although the main goals of these groups are not directly related with the struggle against incineration, their members are showing a high level of engagement with the PAMiR and thus, helping to diversify the movement. Despite the existence of a hierarchy in the movement, determined mainly by the level of commitment, important decisions are taken through direct democracy. There are usually two or three general assemblies called every year, in which the members - the groups, associations and individuals that belong to the PAMiR - discuss the direction that the movement is heading. In every assembly, there is a vote among the participants over decisions that need to be taken, such as the investment of collected funds in attorneys or selection of which protest actions to carry out (interviews 1, 2, 4, 6-8, 11, 14-17, 19, 20).

\subsection{Subalternity as the Main Feature}

When trying to characterize the environmentalism that people from Can Sant Joan have embraced in their struggle against waste incineration in the Asland, the feature that stands out is positionality. The Asland company was funded by the Güell family (prominent among the Catalan bourgeoisie) in 1901, with the Can Sant Joan cement plant built in 1917. From the very beginning, the neighbourhood of Can Sant Joan was a place where the unskilled working class dwelt. In 1989, the French multinational Lafarge became the major shareholder of the Asland company (Lafarge Asland 2001), and in 2014 it changed to LafargeHolcim after merging with the Swiss company (Raymond 2014). Nevertheless, people from Can Sant Joan are not concerned about the ownership of the cement plant and they still call it the Asland. For them, whatever the nationality of the managers, the factory represents the oppression by a ruling group of a poor working-class community with the acquiescence of the authorities. This fact alone could be significant enough as to consider it a case of subaltern environmentalism. Nevertheless, by comparing the case study with the blueprint developed in section 2 (see table 1), more evidence will be given as to support this characterization. 
People in Can Sant Joan have a broad conception of what constitutes the environment. For them, the environment is not only nature, but the urban spaces where they live and even their own bodies. They have learned to identify a strong relationship between the environment and their health, and thus they are concerned about waste incineration in the Asland. They relate the high rate of respiratory diseases and cancer in the neighbourhood (interview 18) with the cement plant activities. The movement against waste incineration in the Asland is about livelihood in the neighbourhood; it is a material conflict mainly played out in the environmental health field. As such, the community has a direct personal connection with the issues of concern: what is in dispute is their own bodies and lives. Even if the community had a previous identity before the start of the struggle, characterized mainly by being working-class migrants (interviews 1, 2, 4-11, $13-17,19,20)$, it has been reshaped through the conflict. The feeling of being despised and sacrificed because of its subordinated social and political position is now the main feature of the social group: a feature that has been expanded beyond the borders of the neighbourhood. In fact, the perseverance of the PAMiR to bridge alliances at regional, national and international level has led to the creation of a new social group formed by communities with similar problems, whose shared identity is based on material concerns, as well as subaltern consciousness. Nevertheless, it is worth mentioning that the core of the movement in Can Sant Joan is formed by a group of people of similar characteristic: aged Spanish males. Whereas women and young people are currently trying to be integrated into the movement, groups of newly arrived migrants - mainly foreigners - are still not getting involved. Most of these recently arrived people are not involved because they do not perceive it as a livelihood struggle. Overcoming the social division and raising awareness among new groups of migrants is the biggest challenge of the PAMiR when it comes to increasing their social mass in Can Sant Joan. Another feature of the movement against waste incineration in the neighbourhood that is related to subaltern environmentalism is its political load. Among the core group of 8-10 people mostly involved in the PAMiR, most of them are openly communist or anarchist, and have been actively involved in political activism in the past (interviews $1,2,8,14,16,17$ ). This small group of people consider their environmental activism embedded in their political ideology. Ultimately, they seek to empower a subaltern community against the ruling group. Even if the PAMiR is not officially positioned in the political spectrum, what has permeated from the core group is an articulation of the struggle around social justice and equity. Thus, although most of the people involved in the movement are not aware of political theory, they perceive corporations and governments as the ultimate perpetrators of the environmental burdens that they are experiencing. Although the platform does not support any particular party, most of the people involved in the 
PAMiR identify themselves with the new left movement and are openly positioned against neoliberal capitalism. "We know well that we are intruding into the heart of capitalism, but we are not afraid" asserts M.G., local activist and member of the neighbourhood association. Again, the political orientation of the PAMiR is strongly influenced by the positionality of the community of Can Sant Joan, that has emerged as the main feature of the movement. Although many of the aforementioned features could fit in different forms of alternative environmentalism, the subaltern consciousness of the people in Can Sant Joan (which has developed into a neighbourhood detached subaltern identity shared with other communities) shapes the struggle more than anything else. In fact, in Can Sant Joan the struggle is not only lived as an environmental health conflict, but as a quest for autonomy and outwards subalternity.

\section{Conclusion}

After the Asland cement plant secured permission in 2006 for using refuse-derived fuel, a movement against waste incineration emerged in Can Sant Joan as the last stage of a lifelong rivalry between the factory and the community. Organized around the heavily politicized neighbourhood association, the neighbours have been fighting for environmental health as much as for social justice. The environmental struggle is a vehicle to free themselves from what they perceive as structural discrimination. A strong tradition of struggles for improving livelihood conditions in the neighbourhood has infused a subaltern consciousness in the community. Nevertheless, by building coalitions with other communities at different geographical levels the Can Sant Joan identity is simultaneously being reshaped, becoming a subaltern geographically-detached complex identity, in common with other communities. The networks of resistance to waste incineration are protecting the environment as a way of protecting their own neighbourhoods, homes and bodies; and thus, they reject the idea of the natural in opposition to the urban. In the end, they live the environmental struggles as a way of reversing the relationships of domination subordination through which they are being discriminated and, ultimately, move up in the Gramscian ladder outwards subalternity. All these characteristics match the blueprint developed in section 2. Accordingly, the case of Can Sant Joan presents a prime example of subaltern environmentalism.

To conclude, subaltern environmentalism is a very comprehensive type of alternative environmentalism. It is not focused on specific causes of marginalization of communities, but rather on resisting dynamics of intentional environmental discrimination of subaltern communities by political and economic elites. The movement is defined by four main features. First, subaltern environmentalists fight for social, as much as for environmental 
justice and thus, it is a movement politically loaded and specifically close to leftist stances. Second, as obvious as it may seem, subaltern environmentalism is embraced by subaltern communities that are previously defined as a group, and whose identity is reshaped through the struggles. Third, in subaltern environmental struggles the city/nature dualism is left behind. Thus, the environment becomes the place where everyday life happens, including urban spaces and even human and more-than-human bodies. Last but not least, the movement is strongly shaped by the subaltern positionality of the involved communities. Accordingly, it results in materialist struggles, lived in first person, in which challenging domination - subordination relationships is the means for improving livelihood in the community.

\section{Acknowledgments}

I am immensely grateful to professor Marco Armiero for his close mentorship and guidance in the research that led to this chapter. I am also grateful to the KTH Environmental Humanities Laboratory for the institutional support received during my research. Last but not least, I thank Alex Franklin for her English proofreading and further suggestions that helped me to improve this chapter. 


\section{Appendix}

List of the interviews referred to in the text, that I personally conducted during my fieldwork.

\begin{tabular}{|c|c|c|c|c|}
\hline ID & Name & Description & Date & Place \\
\hline 1 & J.L.C. & $\begin{array}{l}\text { Can Sant Joan neighbor, president of the neighbourhood } \\
\text { association }\end{array}$ & $6 / 02 / 2017$ & AVV Can Sant Joan \\
\hline 2 & M.G. & $\begin{array}{l}\text { Can Sant Joan neighbor, board member of the } \\
\text { neighbourhood association }\end{array}$ & $6 / 02 / 2017$ & AVV Can Sant Joan \\
\hline 3 & J.M. & Retired surgeon, activist at CAPS & $6 / 02 / 2017$ & Online questionnaire \\
\hline 4 & R.M.M. & Can Sant Joan neighbor, member of the women group & $7 / 02 / 2017$ & AVV Can Sant Joan \\
\hline 5 & N.F. & Can Sant Joan neighbor, member of the women group & $7 / 02 / 2017$ & AVV Can Sant Joan \\
\hline 6 & C.K. & Can Sant Joan neighbor, member of the youth group & $7 / 02 / 2017$ & Montcata Vins \\
\hline 7 & A.D. & Can Sant Joan neighbor, member of the youth group & $7 / 02 / 2017$ & Montcata Vins \\
\hline 8 & A.P. & $\begin{array}{l}\text { Can Sant Joan neighbor, board member of the } \\
\text { neighbourhood association }\end{array}$ & $8 / 02 / 2017$ & AVV Can Sant Joan \\
\hline 9 & S.O. & Can Sant Joan neighbor, member of the women group & $8 / 02 / 2017$ & AVV Can Sant Joan \\
\hline 10 & C.M. & Public health inspector for the MiR municipality & $8 / 02 / 2017$ & City Hall of MiR \\
\hline 11 & A.R. & Can Sant Joan neighbor, member of the women group & $8 / 02 / 2017$ & AVV Can Sant Joan \\
\hline 12 & S.C. & Representative of APQUIRA & 9/02/2017 & La Garriga, private house \\
\hline 13 & N.V.L. & $\begin{array}{l}\text { Member of EeA and former worker of the MiR municipality } \\
\text { in the environment area }\end{array}$ & $10 / 02 / 2017$ & Barcelona, private house \\
\hline 14 & S.H. & $\begin{array}{l}\text { Can Sant Joan neighbor, former rector of the Can Sant } \\
\text { Joan parish }\end{array}$ & $13 / 02 / 2017$ & $\begin{array}{l}\text { Can Sant Joan, private } \\
\text { house }\end{array}$ \\
\hline 15 & G.G. & CUP representative at the MiR municipalaity & $13 / 02 / 2017$ & City Hall of MiR \\
\hline 16 & A.L. & MiR neighbor & $14 / 02 / 2017$ & AVV Can Sant Joan \\
\hline 17 & L.L. & $\begin{array}{l}\text { Can Sant Joan neighbor, board member of the } \\
\text { neighbourhood association }\end{array}$ & $14 / 02 / 2017$ & AVV Can Sant Joan \\
\hline 18 & C.V. & $\begin{array}{l}\text { Endocrinologist specialized in environmental health, } \\
\text { former member of the Catalan parliament, member of } \\
\text { CAPS }\end{array}$ & $15 / 02 / 2017$ & Barcelona, private office \\
\hline 19 & I.H. & $\begin{array}{l}\text { Can Sant Joan neighbor, member of the parent's } \\
\text { association of the Escola El Viver, member of ICV at the } \\
\text { MiR municipality }\end{array}$ & $15 / 02 / 2017$ & Escola El Viver \\
\hline 20 & A.A. & $\begin{array}{l}\text { Can Sant Joan neighbor, initiator of the campaign "Judici } \\
\text { a la Cimentera" }\end{array}$ & $10 / 03 / 2017$ & Skype \\
\hline
\end{tabular}




\section{Acronyms}

AVV

MiR

CAPS

EeA

APQUIRA

CUP

$\mathrm{ICV}$
Associació de Veïns (neighbourhood association)

Montcada i Reixac (name of the municipality to which Can Sant Joan belongs)

Centre d'Anàlisi i Programes Sanitaris (Center for Healthcare Analysis and Programmes)

Ecologistes en Acció (Environmentalists in Action)

Associació de Persones Afectades per Productes Químics i

Radiacions Ambientals (Association of People Affected by

Chemical Products and Environmental Radiation)

Candidatura d'Unitat (Popular Popular Unity Candidacy)

Iniciativa per Catalunya Verds (Green Catalonia Initiative)

\section{Bibliography}

Agyeman, Julian (2005). Sustainable communities and the challenge of environmental justice. New York: New York University Press.

Armiero, Marco; D’Alisa, Giacomo (2012). "Rights of Resistance: the Garbage Struggles for Environmental Justice in Campania, Italy". Capitalism Nature Socialism, 23(4), 52-68.

Armiero, Marco; Sedrez, Lise (2014). "Introduction". Armiero, Marco; Sedrez, Lise (eds.), A History of Environmentalism: Local Struggles, Global Histories. London: Bloomsbury Academic, 1-19.

Barca, Stefania (2012). "Working-class Environmentalism". Interface: a Journal for and about Social Movements, 4(2), 61-80.

Berg, Bruce L.; Lune, Howard (2012). Qualitative Research Methods for the Social Sciences. 8th ed. Boston: Pearson.

Bullard, Robert D. (2008). Dumping in Dixie: Race, Class, and Environmental Quality. Boulder (CO): Westview Press.

Bullard, Robert D.; Johnson, Glenn S. (2000). "Environmental Justice: Grassroots Activism and Its Impact on Public Policy Decision Making". Journal of Social Issues, 56(3), 555-78.

Corburn, Jason (2005). Street Science: Community Knowledge and Environmental Health Justice. Cambridge (MA): Massachusetts Institute of Technology Press.

Di Chiro, Giovanna. (2016). "Environmental Justice”. Adamson, Joni; Gleason, William; Pellow, David (eds.), Keywords for Environmental Studies. New York: New York University Press, 100-5.

Egan, Michael (2002). "Subaltern environmentalism in the United States: A historiographic review". Environment and History, 8(1), 21-41. 
Energy Justice Network (s.d.). Targeting "Cerrell” Communities [online]. URL http://www.ejnet.org/ej/cerrell.pdf (2017-03-28).

Epstein, David G. (1973). Brasilia, Plan and Reality: a Study of Planned and Spontaneous Urban Development. Berkeley (CA): University of California Press.

Gleeson, Brendan; Low, Nicholas (2002). Justice, Society and Nature: An Exploration of Political Ecology. London: Routledge.

Goodman, James; Salleh, Ariel (2013). “The 'green economy': Class Hegemony and Counter-hegemony". Globalizations, 10(3), 411-24.

Gramsci, Antonio (1971). Selections from the Prison Notebooks. Eng. Transl. and Ed. by Quintin Hoare, Geoffry Nowell Smith. New York: International Publishers.

Gramsci, Antonio (2011). Prison Notebooks, vol. 2. Eng. Transl. by Joseph A. Buttigieg. New York: Columbia University Press.

Green, Marcus. (2002). "Gramsci Cannot Speak: Presentations and Interpretations of Gramsci's Concept of the Subaltern". Rethinking Marxism, 14(3), 1-24.

Guha, Ranajit. (1982). Subaltern studies I: Writings on South Asian history and society. Oxford: Oxford University Press.

Guha, Ramachandra. (1989). "Radical American Environmentalism and Wilderness Perservation: a Third World Critique”. Environmental Ethics, 11(1), 71-83.

Hagan, Frank E. (2006). Research Methods in Criminal Justice and Criminology. 7th ed. Boston: Allyn and Bacon.

Asland (2001). Asland, una historia del siglo XX (1901-2001). Barcelona: Lafarge Asland.

Lerner, Steve (2010). Sacrifice Zones: the Front Lines of Toxic Chemical Exposure in the United States. Cambridge (MA): MIT Press.

Martínez Alier, Joan (2003). The Environmentalism of the Poor: a Study of Ecological Conflicts and Valuation. Cheltenham (UK): Edward Elgar Publishing.

Martínez Alier, Joan (2016). “Environmentalism(s)”. Adamson, Joni; Gleason, William; Pellow, David (eda.), Keywords for Environmental Studies. New York: New York University Press, 97-100.

Nash, Roderick ([1967] 2014). Wilderness and the American Mind. New Haven (CT): Yale University Press.

Novotny, Patrick (2000). Where We Live, Work, and Play: the Environmental Justice Movement and the Struggle for a New Environmentalism. Westport (CT): Greenwood Publishing Group.

Pellow, David (2000). “Environmental Inequality Formation: Toward a Theory of Environmental Injustice". American behavioral scientist, 43(4), 581-601.

Pulido, Laura (1996). Environmentalism and Economic Justice: Two Chicano Struggles in the Southwest. Tucson: University of Arizona Press. 
Raymond, Grégory (2014). "Fusion Lafarge-Holcim: un poids lourd du CAC40 quitte la France" [online]. The Huffington Post. URL http:// WWW. huffingtonpost.fr/2014/04/07/fusion-lafarge-holcim-impotsnumericable_n_5103206.html (2017-05-23).

Spivak, Gayatri (1988). "Can the Subaltern Speak". Nelson, Cary; Grossberg, Lawrence (eds.), Chicago: University of Illinois Press, 271-313.

Yin, Robert K. (2003). Case Study Research: Design and Methods. 3rd ed. Thousand Oaks (CA): Sage Publications. 



\author{
Through the Working Class \\ Ecology and Society Investigated Through the Lens of Labour \\ edited by Silvio Cristiano
}

\title{
Urban Social Movements in Rio de Janeiro The 'Missing' Environmental Question
}

\author{
Federico Venturini \\ (Independent activist-researcher)
}

\begin{abstract}
Rio de Janeiro is suffering from increasing environmental damage. Urban social movements in the city, however, seem not to be considering this issue at the same level as other issues. The absence of a manifest environmental consciousness by urban social movements in Rio de Janero is striking, particularly from a social ecology point of view. It would seem crucial for them to consider and take action to protect the environment, not only because of the local negative environmental issues, but also for the broad climate change effects connected with them. It seems that urban social movements in Rio de Janeiro follow a pattern in which only when a basic standard of living is ensured and minimal working rights are guaranteed, can they start claiming other rights and concentrate on environmental problems. This work suggests that the holistic approach of social ecology can help urban social movements to have a more understanding of the social and ecological impacts of various projects and solve the dichotomy Brown vs Green agenda.
\end{abstract}

Summary 1 Introduction. -2 Introducing the Motor of Social Ecology: between Ecology, Freedom and Domination. - 3 The Ecological Crisis in Rio de Janeiro. - 4 The 'Missing' Environmental Question. -5 Conclusions.

Keywords Urban social movement. Rio de Janeiro. Green agenda. Brown agenda. Social ecology.

\section{Introduction}

At the beginning of June 2013, in many cities in Brazil, a series of mobilisation against a general increase of the price of public transport fares started to take place. These mobilization, developing and incorporating other demands, in few weeks time reached an incredible magnitude of "popular mass revolt" (Gohn 2014, 8). Rio de Janeiro was undoubtedly at the forefront of all the mobilisations since June-July 2013, for number of people mobilized and intensity (Cava 2013; Cava, Cocco 2014; Venturini 2016). The 2014 FIFA World Cup can be seen as the end of this cycle of intense mobilisations that started in June 2013.

This work is based on a 12 month research that I conducted in the city of Rio de Janeiro between March 2013 and August 2016. I believe that research can be an invaluable tool for the advancement of social and political

Culture del lavoro 8 ISSN [online] 2610-9379| ISSN [print] 2610-8852

DOI 10.30687/978-88-6969-296-3/004 | Submitted: 2018-07-20 | Accepted: 2018-08-31

ISBN [ebook] 978-88-6969-296-3 | ISBN [print] 978-88-6969-297-0

(c) 2018 | (1) Creative Commons Attribution 4.0 International Public License 
struggles (Harvey 2001; Pickerill, Chatterton 2006). For this reason my research has been informed by a militant research approach (Shukaitis, Graeber 2007), putting emphasis on learning about, with and from people in contraposition to researching on urban social movements (Venturini 2016). Participating in the daily life of local urban social movements in Rio de Janeiro I was able to observe and highlight their position on the urban ecological crises in the city, guiding my analysis. In this work, I refer to urban social movements in Rio de Janeiro, focussing to all that organised groups that were acting during the 2013-2016 mobilisations.

My analytical framework is based on social ecology, a theory developed by Murray Bookchin with the aim to assess and solve the current social and environmental crises, conceived as direct consequences of capitalism and all forms of domination. Social ecology is a powerful analytical tool of current crises and a theory of action that offers strategies, ethics and a reconstructive vision for a future society. ${ }^{1}$

Examining the complex understanding of urban crises by urban social movements, and their tactics and organisational strategies, I trace points of contact between urban social movement in Rio de Janeiro and the social ecology perspectives. This work bridges these two, highlighting how urban social movements' practices and visions, and the social ecology theory can benefit from each other, in order to build relevant and decolonised knowledge for social change.

This article is structured as follow: first I introduce the core of social ecology, second I highlight the ecological crises in Rio de Janeiro, third I consider what I called the 'missing' environmental question and the possible contributions of social ecology, and then I end with some conclusions.

1 For an introduction to social ecology see (White 2008, Price 2012, Venturini forthcoming). 


\section{Introducing the Motor of Social Ecology: between Ecology, Freedom and Domination}

Social ecology is based on challenging social hierarchy and social domination, with a theoretical elaboration that attempts to go beyond the Marxist idea of social class and State and at the same time imposes an ecological viewpoint. This elaboration is based on the idea that "the domination of nature by man stems from the very real domination of human by human" (Bookchin 2005, 65). Crucially, for social ecology, "nearly all our present ecological problems arise from deep-seated social problems" (Bookchin 1993, no page).

Social ecology argues that environment and society are inextricably linked to each other. Nowadays both labour and nature are considered and treated as commodities (O'Connor 1997) and the pressing planetary environmental problems (Klein 2014, Turner 2014, Global Footprint Network 2015, Steffen et al. 2015) can be addressed only by facing the social problems within society. As stated in a recent interpretation and reassessment of Bookchin's work by Price (2012), all of social ecology is thus grounded in the fundamental ontological understanding that hierarchy and domination "were in place before the emergence of the surplus. Thus, in the Bookchin programme, they are not the inevitable by-product of the move to an economic world; they are not, perhaps most importantly, the by-product of a human project to dominate a stingy, harsh natural world" (157), but are born further back in human history with the emergence of gerontocracy. This understanding is the central motor of social ecology (Price 2012) on which the entire social ecology theory and its arguments are grounded.

This idea deviates from the classical Marxist tradition and uses concepts that help us move beyond an analysis based on solely economic relationships towards building a greater understanding of dominations. Indeed also Barca (2014) stressed that "working-class communities are far from being unified social entities entirely corresponding to theoretical definitions of their class identity, interests, and behavior" (14). Similarly "working-class environmental consciousness [does not] entirely coincide with the politics of Labor parties or unions" (Barca 2014, 14). For this reason Bookchin (1986a; 2005) stresses the importance of concentrating on domination and hierarchy, and away from a focus on class and exploitation, hoping to build a new political movement.

The organic world is defined "as an evolutionary process" (Bookchin 1995a, 17) in which two different kinds of nature to which human beings belong coexist: 'first nature' and 'second nature', where the former is related to organic or biological evolution and the latter to a unique human social evolution (Bookchin 1995a, 2005). As well-summarized by White (2008), in social ecology, humans are "nature rendered self-conscious" 
(109). Second nature developed from first nature, not in opposition to it. Many western thinkers offered a dichotomy between non-human nature and human society (Pepper 2003), whilst for social ecology humankind plays a multifaceted role within nature, being a unique expression of it, still part of it, but often acting in an antagonistic way toward it.

In this way social ecology critiques both the tendencies of anthropocentrism (where humanity is considered superior to nature) and deep ecology (where humans have to return to nature). Social ecology proposes a different approach, understanding the uniqueness of human progress in parallel with natural evolution and proposing, at the same time, an organic point of view in analysing the problem (Bookchin 1996a, Staudenmaier 2005).

Social ecology is focused on rationally analysing humans' 'second nature' and understanding, within it, the origins of social hierarchy and domination. This analysis starts with early human communities; what Bookchin calls 'organic societies', "spontaneously formed, non-coercive and egalitarian" (White 2008, 36). In these societies, woman and man had two different realms, with different functions and culture, the "sororal society of women" and the "fraternal society of men" (Bookchin 1986a, 18). Other important features of organic societies were the absence of the idea of human destiny to rule nature, the common usufruct of land, the presence of an irreducible minimum for everyone (e.g. food, shelter, etc.), the equality of unequal, the commitment to freedom, and cooperation. In these societies humanity is thus viewed as part of nature, the concept of domination is not yet developed and women and men lived in balance. In Bookchin's interpretation, the first form of domination emerged from organic societies: that of the elders over the young. Following this analysis, "the notion that all ecological problems are social problems, [...] stem[s] in the first instance from the emergence of hierarchy in its nascent form in the gerontocracy" (Price 2012, 157). On this point Bookchin is very clear and he also stresses that the concept of domination of nature is a human construct that does not exist in the first nature: "what we talk about when we speak of 'the domination of nature' is an ideology, not a fact. 'Nature' can no more be 'dominated' than an electron or an atom" (Bookchin 1995d, no page). Moreover, according to this interpretation, social evolution is an effect of "changes in social forms and relationships and not because of the natural reaction to a harsh and necessitarian natural world; [thus] hierarchy as such is perhaps not the inevitable by-product of humanity's historical move through civilisation" (Price 2012, 157). White (2008) underlines possible incoherences of Bookchin's anthropological accounts of organic societies; having acknowledged this problem, it is however important to consider, following the analysis by Graeber (2004), the value of social theories based on ethnographic or anthropological work aimed at outlining and describing alternative possibilities. In this regard, Price (2012), in his reassessing of Bookchin's work, whilst acknowledging the 
necessity of clarifications, underlines the "coherence and unity" (195) of his social history.

Overcoming domination in social forms and relations is thus fundamental for building a new society based on freedom. From a political point of view, by criticizing all forms of dominations, social ecology speaks "with all emancipatory movements" (Morris 2012, 257) with an unifying framework for a general call for action. This call emphasises that changing our social structures can also dialectically change our relationship with nature. With this dialectical process, Bookchin goes beyond the classical Marxist concept that emphasises the contrast between nature and human or indeed between the rural and the urban. In his analysis, this contrast has shaped the development of our society through history, enhancing unbalances and exploitation. Morris (2012) adds that "Marx [...] was preoccupied with the preconditions of freedom (technological development, material abundance) not with the conditions of freedom (decentralization, the formation of communities, direct democracy, and technologies and urban life on a human scale)" (245) and the social ecology project exactly aims to analyse and propose the conditions of freedom. In order to make a substantial change, for a real ecological society, a process of profound reconciliation between nature and human is necessary, pointing at the birth of a new non-hierarchical society based on concepts of freedom and cooperation, going beyond first and second nature (Bookchin 1996a). Only within a unity between nature and humans can there be a complete development of all the human possibilities and potentialities.

\section{The Ecological Crisis in Rio de Janeiro}

The environmental problems in Rio de Janeiro are many and complex: recent policies are in striking contrast to the hope born from the Rio+20 United Nations Conference on Sustainable Development, hosted in Rio de Janeiro in 2012.

First of all, population growth in Rio de Janeiro exploded in the second half of the last century and, despite the fact that the growth has now decelerated (Cox 2013), the city is constantly sprawling (Herzog 2013a; Herzog, Finotti 2013), creating important impacts on the environment. It is a clear example of a city development without control, which threatens all of us, following a model of urbanization that Bookchin clearly warned about (1986b, 1995b). While sprawling, as Souza (1999) points out, Rio de Janeiro is developing the classical socio-environmental problems of a metropolis in the semi-periphery, on one side due to deregulated and fast industrialization typical of core countries, on the other linked to poor settlements, typical of peripheral countries. If during the colonial period Rio de Janeiro was one of the biggest slave hub in the world (Guimarães 
2014), the art exhibition From Valongo to Favela: The Imaginary and the Periphery reminds us of the link between the slavery period and the current situation of favelas' ${ }^{2}$ inhabitants (Cardoso, Diniz 2014). Looking at today favelas' inhabitant, regarded only as cheap and unskilled manpower, in poor living conditions and stigmatized by the society, makes wonder if slavery ever ended.

On one side, living conditions in favelas are very precarious and, often, people living there are the cause ${ }^{3}$ of environmental problems (Souza 2003), like pollution from sewage and garbage.

On the other side, it is important to focus on other and deep problems, connected to the kind of development that Rio de Janeiro is embracing, based on the (re)expansion of the secondary sector, with industries and extractive companies located in the close proximity of the city, in the State of Rio de Janeiro, like the heavy polluted Guanabara Bay (Melo et al. 2006). On the seashore, in particular, three industrial centres (all developed in the last ten years and partially completed or near completion) are at the stage of environmental discussion for their heavy impact on the environment: Complexo Industrial-Portuário do Açu (Industrial and Port Complex of Açu), Complexo Petroquímico do Rio de Janeiro (Petrochemical Complex of Rio de Janeiro, COMPERJ), ThyssenKrupp CSA (Comissão de Defesa dos Direitos Humanos e Cidadania da Alerj 2013). The first project, the Come plexo Industrial-Portuário do Açu, situated in the north-east of the State of Rio de Janeiro, around $300 \mathrm{~km}$ from the city, is not only a super port for goods and minerals but also hosts different industrial infrastructures, like thermal power plants, steel industries, oil treatments, shipyards and cement factories (Prumo 2010). The second, the COMPERJ is a petrochemical complex and is situated less than $50 \mathrm{~km}$ north-east from Rio de Janeiro. The third, the ThyssenKrupp CSA ${ }^{4}$ is an important steel complex, whose construction was started in 2006 and finalised in 2010. It is situated in the Sepetiba Bay, in the western part of Rio de Janeiro.

There is vast literature stressing the impacts of each of these industrial complexes, revealing the strong damages they cause to the environment and on local populations, due to uncontrolled urban development in their surroundings and the disruption of traditional local economy, based on farming and fishing. ${ }^{5}$ Moreover, these are only the last three big examples

\section{Favela is a Brazilian Portuguese word for 'slum'.}

3 The problem is complex: the housing situation in the favelas cannot be reduced to blame individual behaviours but has to be seen as a social production of poverty.

4 In 2017 the entire complex was sold to the Argentinian company Ternium SA.

5 For Complexo Industrial-Portuário do Açu: Coutinho et al. 2009; Quinto et al. 2011; Souza Barreto, Júnior 2013; Rangel, Pessanha 2014. For COMPERJ: Moyses 2010; Dias et al. 2013. 
of a list of industrial complexes that have been developed in the area in the last decades, all with similar impacts and problems. ${ }^{6}$ Unfortunately, despite the (partially) good intentions of the Rio+20 conference, little has changed in Rio de Janeiro in relation to the environment, creating the necessity for urban social movements to fight.

\section{The 'Missing' Environmental Question}

As just introduced, Rio de Janeiro is suffering from increasing environmental damage and problems. Urban social movements, however, seem not to be considering this issue at the same level as the other social issues.

During the period of my fieldwork, very few social movements mobilized around specific environmental issues in Rio de Janeiro. ${ }^{7}$ Only in the case of the industrial complex ThyssenKrupp CSA, the campaign Pare a TKCSA! (Stop TKCSA) built a broad coalition and gained attention (Instituto Políticas Alternativas para o Cone Sul 2012). As a result of the campaign, various legal proceedings are open and threaten the closure of part of the complex (Lorenzi 2013). This success was ensured by the manifest magnitude of the law violations and pollution and the support from local researchers who produced scientific dossiers to help the campaign.

In a country that has seen incredible industrial development over the last few decades and is also facing increasing deforestation, only few major campaigns, such as the campaigns against the use of pesticides, deforestation and the construction of the Belo Monte Dams (Oliveira, Cohn 2014), have reached a national/international audience. It is striking that a significant campaign against the use of nuclear power has never existed, even though Brazil is currently building its third reactor at the Angra nuclear power plant.

An exemplary episode was the announced public sale of the Libra oil field, discovered in 2010, situated at sea, $230 \mathrm{~km}$ from the Rio de Janeiro coast and considered one of the biggest recently discovered oil fields. A campaign developed with the slogans "O petróleo é nosso!" (The oil is ours!) and "Não ao leilão de Libra!" (No to the privatization of Libra!) and it was boosted by the June-July 2013 mobilisations. Due to popular pres-

For ThyssenKrupp CSA: Porto, Milanez 2009; Pato 2010; Instituto Políticas Alternativas para o Cone Sul 2012; Articulação International dos Atingidos e Atingidas pela Vale 2015.

6 For a complete list of the undergoing projects see Sistema FIRJAN 2012; for a map of the main pollutant complex see Rio+Tóxico 2012.

7 An interesting exception is the recent campaign Ocupa Golfe, a small occupation for the defence of the Atlantic Forest, against the construction of a golf resort for the 2016 Olympic Games (Guimarães 2016). 
sure, in 2013 president Dilma modified the selling condition, increasing the revenue for the State to be dedicated to education and health. However, different kinds of social movements, organizations and unions viewed this modification as insufficient and started a campaign, which peaked on the 21 October 2013, the date of the public sale. The event was organized in Rio de Janeiro, the army was mobilized and violent clashes erupted with the demonstrators. Throughout the campaign the main concern was economic, not environmental. In core countries an event of this magnitude on such a sensitive topic as oil would have developed important social movements and public debate on the environmental impacts, questioning the fossil fuel-led model of development (see for example the wide debate on fracking: Celis et al. 2013, Simonelli 2014). There are also examples from other countries from the periphery: in Ecuador the discovery of an important amount of oil in the Yasuní National Park triggered an important public debate on environmental issues and it was a key issue during the 2013 presidential elections (Larrea, Warnars 2009; Marx 2010). Nothing like this has happened in Rio de Janeiro or in Brazil, where the aforementioned mobilisation on the oil field has concentrated only on its privatization and did not touch environmental impacts.

The same can be said of the 2016 Summer Olympic Games hosted in Rio de Janeiro. Despite the environment being the third pillar of the Olympic Movement (IOC 2010), the Olympic Games in Rio de Janeiro failed to maintain all its promises of environmental friendliness (Boykoff, Mascarenhas 2016; Mascarenhas et al. 2017; Mascarenhas 2018). However, environment protection was not the main critique of urban social movements to this mega-event, while they focused more on the creation of a city of exception and its impacts on the urban poor (Almeida, Graeff 2016; Richmond, Garmany 2016).

The absence of a manifest environmental consciousness by urban social movements in Rio de Janeiro is therefore striking, particularly from a social ecology point of view, which directly links social oppression and domination with ecological disasters. It would seem crucial for them to consider and take action to protect the environment, not only because of the local negative environmental issues, but also for the broad climate change effects connected with them. Several recent publications (Maia 2008; Egler 2007; Confaloniere, Marinho 2007; Muehe, Neves 2007) commissioned by the Pereira Passos Institute for the seminar "Rio - Next 100 Years" - The City against Global Warming agreed that Rio de Janeiro is already experiencing increasing temperatures and rains; in the future it will be affected by increasing sea levels, which will threaten a large part of the city, as well as by more frequent extreme weather events with destructive potential (heavy rain, flooding, landslides, oceanic events).

There are various analytical frameworks, which can help us understand why urban social movements in Rio de Janeiro seem not to be concerned 
with environmental issues. One of them is that set out by McGranahan and Satterthwaite (2000), which distinguishes between a Green agenda and a Brown agenda: the former is framed around nature preservation, the latter around improving the condition of the population. The Brown agenda is concerned first and foremost with human health and does not have a general overview of the ecosystem problems considered in the Green agenda (McGranahan, Satterthwaite 2000). In Brazil the first is mainly advocated by indios ${ }^{8}$ (indigenous people) and quilombola (descendants of Afro-Brazilian slaves who escaped from slave plantations) settlements in non-urban contexts, the second by groups, mainly urban poor, impacted by urban environmental problems (Lopes 2006). Moreover, as stressed by Porto (2012), urban environmental problems in Brazil are usually not considered as part of any 'environmental justice' agenda, despite the fact that "an expressive portion of the urban population lives in slums and places without appropriate urban infrastructure, frequently in risk areas of flooding, garbage sites, industrial pollution, and major accidents" (102). From this perspective, urban social movements in Rio de Janeiro focus on the Brown agenda, seeing it as an integrated part of the struggle for a reforma urbana. In different Brazilian cities urban social movements fight for sanitation and housing together with "associations organized by residents around waste and hazardous sites or by workers contaminated by chemicals" (Porto 2012, 102). Thus the focus of urban social movements is on environmental effects on humans and this concern is problem solving centred, often focussing on the solutions to specific, stringent and contingent necessities of the poor population. My interviews in Rio de Janeiro also stressed the severe issues of housing and sanitation in favelas. These are seen as political problems. Priscilla, an activist-researcher that I interviewed, is quite clear in underlining that these problems can be defined as "diseases of poverty". She also adds that "they are political diseases, if people would have sanitation they would not be sick, children would not die".

What is missing from this conception is a connection between the Green and Brown agenda. When I asked Pedro and Matheus, both living in favelas and active in urban social movements, about the environment, they both stressed the importance of trees in favelas; therefore interpreting the environmental question in a rather narrow way, failing to consider wider problems. These answers were not followed up in the interviews, but seem in accord with a 'Brown-agenda-only' view: environmental issues are addressed only when contingently impacting on humans, with a very limited view of the links between social and ecological problems.

8 While the term indio is often derogatory in Spanish, I use here the term 'indios' to refer to indigenous people because it is the term they use to call themselves in Portuguese. 
During my time in Rio de Janeiro I never saw important demonstrations or debates on environmental issues. I witnessed only few small static demonstrations: for example for the Pare a TKCSA! campaign or for animal rights.

The same applies to the critiques of mega-events/mega-projects that have always been framed by urban social movements in Brown agenda terms, always from an economic or human perspective and in very few cases from an environmental one, as evident from the content of flyers or slogans used in mobilisations. Only a few people raised these issues in assemblies and meetings but they were normally ignored and participation in (static) demonstrations was very low. The people more involved on these issues were indios from the Aldeia Marakanã collective.

The evidence of this lack of attention given to the environmental sphere is supported by the lack of environmental themes coming out from the interview analysis. Only members of the Aldeia Marakanã collective and Lucio, an activist and long-time member of an international environment NGO, articulated a discourse on the environment and underlined my suppositions. The movement in Rio de Janeiro is not interested in environmental issues and embraces or overlooks the western concept of 'development'. The Brown agenda, which aims to ameliorate peoples' material living conditions, is linked to the idea of development and whatever obstructs this development is seen negatively. A Green agenda, that questions the model of development (opposing deforestation, greenhouse emissions, Belomonte projects, for the preservation of ecosystems, etc.), is often ostracised and seen as a bourgeois or a core country priority. Speaking about the Brazilian social movements, Lucio is very clear:

Historically, the Left itself does not have this connection with the environmental issue, the Left also had and still has this developmental idea, in order to have progress, you need to develop the industry and to develop the industry you do whatever is necessary.

Urban social movements do not differentiate themselves from the broader Brazilian society which continues with the same old idea of development (Cava 2013) and they seem to be linked to a heterodox conception of Marxism where progress is seen as industrial development which must be achieved at any cost. In urban social movement view, rapid industrialization would lead to better conditions for the workers, in a country where many people are still below the poverty line. In this way, whoever has an environmental concern could be labelled as right wing or conservative and against the progress of the working class. In this thinking, environmental costs are not taken into account or are unevaluated; moreover, other forms of 'development' are not explored. Nevertheless, Brazil is a country facing incredible development, but is still at an early stage of market-driven change: it still has the opportunity to choose a different path. 
Sustainable development has been a pillar of the Partido dos Trabalhadores (Workers' Party, PT) government since it was founded (Sader 2013). This approach has been widely criticised in the broad literature for its embedded contradiction of putting together sustainability and development (Redclift 1987, Campbell 1996, Banerjee 2003).

The importance of the discourse of sustainable development can also be observed in the Brazilian Green Party: despite being formed in the 1980s by Left ex-guerrilla members, it is commonly seen as a centre party and its Manifesto states very clearly that the party "does not trap itself in the narrow polarization between left and right. It is at the front" (Partido Verde 2005, 1). The Green Party is also trapped in the 'sustainability' paradigm, in that it advocates sustainable development and Green technology, not deeply challenging the system. This attitude can be seen as a legacy of the perception of Brazilian Green politics during its development the 70s and 80s. As Jacobi (2003) points out: social movements were more concerned about meeting basic needs, and also the military leadership was managing a strong economy. At that time:

The ecologist's proposals had no influence on the future of Brazilian society. [Still today], in a discourse where the developmental myth appears as only one capable of overcoming the terrible problems facing the country, the discourse on the need to preserve the environment emerged as the antithesis of national development. (Jacobi 2003, 6-7)

Environmental issues are thus not on the public agenda nor are they a major concern of the population. For this reason, urban social movements do not strongly focus on environmental issues. In Brazilian society the preferred actor on environmental matters remains the NGOs, which are however limited in their sphere of action and accomplishments (Alonso, Costa 2002).

The Brazilian national economy today dictates the unrestricted and uncontrolled growth of Brazilian cities, with grave environmental consequences. Despite the massive environmental problems that affect Rio de Janeiro and Brazil, few activists pay attention to these issues. Contemporary urban social movements focus their attention on the urgent question of survival, which is still not guaranteed for a large part of the urban population (Shigetomi, Makino 2009). In a society of sharp class divisions, they prioritize the fight against class domination, and they see environmental problems as secondary to the basic needs of human life. Urban social movements follow a pattern in which only when a basic standard of living is ensured and minimal working rights are guaranteed, can they start claiming other rights and concentrate on environmental problems.

This failure to address ecological issues clearly weakens the struggle against capitalist domination, and fails to identify the nature of the cur- 
rent crises or comprehend their full scope. This also makes it difficult for us to find viable and holistic alternatives. As social ecology explains, only by addressing the concept of domination over nature as stemming from the domination of humans over humans can social movements work for a real alternative that reconnects humans to nature. Only by acknowledging that current social and environmental crises, as connected together, are structurally built into the very system of capitalism can the social movements start building holistic and viable alternatives. Moreover, the class struggle that is still intensely present in countries from the semi-periphery, like Brazil, or periphery, could, in a social ecology framework, assume a new centrality and meaning as struggles against one form of domination of humans by humans: it is the broader concept of domination that provides the framework for explaining social struggles in their specific movement contexts, as well as their geographical, cultural, and historical peculiarities. Without falling into a Marxist understanding of the role of the proletariat, social ecology is able to advance the class component in social movement theory, looking at it through the lens of domination. According to this analysis, then, we can interpret social movements primarily as struggles against domination, even though this struggle is framed differently in different contexts. Class struggle can then be integrated into a coherent struggle against all forms of domination. However, when urban social movements allow, referring to the Brown agenda, the struggle over economic concerns to exclude ecological concerns, which is what Brazilian activists currently do, their vision and sphere of action are greatly limited. The holistic approach of social ecology can help urban social movements to have a deeper understanding of the social and ecological impacts of various projects. At the same time, it could be used to harmonize the Brown and Green agenda together, offering more comprehensive solutions that address the man's impacts on humans and non-humans. Finally, social ecology offers a solution that goes beyond the dichotomy of Brown and Green agenda, acknowledging that environmental crisis stems from human' domination.

\section{Conclusions}

The current form of urban development, shaped by the capitalist system (Harvey 1973, 2001, 2012) and based on the denial of the right to the city and spatial justice, is not what urban social movements envision. This denial takes various forms, such as gentrification, eviction, socio-spatial segregation, urban poverty, mobility poverty, etc. and is implemented with the support of governmental structures that work to accommodate the interests of elites. In Rio de Janeiro's current urban development, urban social movements have understood that the scale of the use of mega-projects and mega-events facilitate capital reproduction in the interest of these elites. 
With this understanding of the urban crisis, urban social movements prioritize what they see as more urgent and impactful. Urban social movements' perception of urban crises is framed by different aspects of those crises: the scale of the phenomena (e.g. the scale of denial of the right to the city); its presence/importance in the popular discourse; the direct impact on people's everyday lives (for example how big and urgent those impacts can be; if a favela is evicted, urban social movements will run there to support residents, leaving other struggles for later). Mega-events have a very vast scale: they appear as a new face of neo-colonialism, pushed by foreign investments; they are part of the popular, national and international discourse and, because of their reshaping of the city, are impacting on everyday lives on a time span that lasts for several years. Also, transportation issues cover the entire urban scale and are within the daily discourse of the whole population and impact on everyday lives, as seen in the 2013 mobilisations (Venturini 2016). On the contrary, the impacts on everyday lives of other mega-projects such as the ThyssenKrupp CSA, despite a vast scale, are not immediately seen or perceived by the population and are not widely discussed in the society.

So they are yet not a goal for urban social movements that are constrained to focus on more 'urgent' issues. The same applies to the environmental question, as mentioned in this work: the impacts are not felt in peoples' everyday lives, and even when an environmental related tragedy happens, the reasons are to be found in bad governance more than in climate change. Despite the huge dimensions of environmental issues for the urban poor (Martinez Alier 2005), the popular discourses are framed around the Brown agenda.

Urban social movements are committed to action and are forced by their limited resources to focus on certain struggles, in order to fight for direct gains in everyday battles, to solve urgent, life threatening issues. Mega-events are perfect national/international stages for protests in order to send powerful messages of dissent. While this work focussed on groups acting in the 2013-2016 mobilisations, these findings express a historical trend in Rio de Janeiro.

Urban social movements have developed a critique of contemporary city development very similar to the one proposed by social ecology, where a rampant urbanization is interpreted as being led by the advantage of the few and at the expense of the poor. However, no work on mega-projects and mega-events have been carried out in the social ecology tradition. Furthermore, the analysis of mega-events is connected to the need to understand neo-colonialism, a form of domination that social ecology should take more widely into account (Venturini 2015). Despite it goes beyond the scope of this work, mega-projects and neocolonialism are key topics where social ecology can learn frowm social movements. 
If, on one side, social ecology can benefit from learning from urban social movements' analysis, on the other, social ecology could inform their practices and visions. In particular, the use of the concept of 'domination' allows a more holistic vision of the social issues. Social ecology does not single out specific struggles, but moves holistically against domination, with a broader understanding of crises. Social ecology, highlighting the link of all forms of domination, not only calls for the coordination of different struggles that urban social movements pursue, in order to reinforce them, but also highlights the need to focus on a change that is broader and more fundamental.

For example, it is possible to highlight that urban social movements are concentrating all their efforts and critiques on the mega-events, forgetting the impacts of the mega-projects that are being planned in parallel in the State of Rio de Janeiro, as for example during the mobilisations in 2013-2016 (Cava 2013; Cava, Cocco 2014; Venturini 2016). The reasons for this approach are several: firstly, they are considering what they are seeing happening in the city; secondly, they are focussed only the investments that are in the main stream, having to face the enormous number of fronts of struggle; thirdly, they have not produced a critique of the idea of development, that lays at the base of these projects. Moreover, urban social movements, specifically because of their urban nature and manifestation, are often unable to detect the connection of the future of their urban environment with the broad territory of the State and the capitalist development of its economy. The mega-projects are going not only to have a dramatic impact on the social and economic future of Rio de Janeiro, but also are going to take a heavy environmental toll. Let's work together toward the "right to be environmentalist" (Barca 2014, 21). 


\section{Bibliography}

Almeida, Barbara; Graeff, Bill (2016). "Displacement and Gentrification in the 'City of Exception': Rio de Janeiro towards the 2016 Olympic Games". Bulletin Journal of Sport Science and Physical Education, 70(May), 54-61.

Alonso, A.; Costa, V. (2002). "Por uma Sociologia dos Conflitos Ambieno tais no Brasil". Alimonda, Hector (ed.), Ecología Política: Naturaleza, Sociedad y Utopía. Buenos Aires: Clacso, 115-35.

Articulação International dos Atingidos e Atingidas pela Vale (2015). Relatório de Insustentabilidade da Vale [online]. URL https://atingidospelavale.files.wordpress.com/2015/04/relatirio_pdf.pdf (201808-20).

Banerjee, Subhabrata Bobby (2003). "Who Sustains whose Development? Sustainable Development and the Reinvention of Nature". Organization Studies, 24(1), 143-80.

Barca, Stefania (2014.) Laboring the Earth: Transnational Reflections on the Environmental History of Work. Environmental History, 19(1), 3-27. Bookchin, Murray (1986a). The Modern Crisis. Philadelphia: New Society. Bookchin, Murray (1986b). The Limits of the City. Montreal: Black Rose Book.

Bookchin, Murray (1993). "What is Social Ecology" [online]. Anarchy Archive. URL http://dwardmac.pitzer.edu/Anarchist_Archives/bookchin/ socecol.html (2018-08-20).

Bookchin, Murray (1995a). Re-enchanting Humanity: A Defense of the Human Spirit Against Anti-Humanism, Misanthropy, Mysticism and Primitivism. London: Cassell.

Bookchin, Murray (1995b). From Urbanization to Cities: Toward a New Politics of Citizenship. New York: Cassell.

Bookchin, Murray (1995d). "Reply to Moore" [online]. Social Anarchism. URL http://www. socialanarchism.org/mod/magazine/display/25/index.php (2018-08-20).

Bookchin, Murray (2005). The Ecology of Freedom. Oakland: AK Press. Boykoff, Jules; Mascarenhas, Gilmar (2016). "Rio 2016: Urban policies and environmental impacts". Idées d'Amériques, 7.

Campbell, Scott (1996). "Green Cities, Growing Gities, Just Cities?: Urban Planning and the Contradictions of Sustainable Development". Journal of the American Planning Association, 62(3), 296-312.

Cardoso, Rafael; Diniz Clarissa (2014). "From Valongo to Favela: The Imaginary and the Periphery" [online]. Museu de Arte do Rio. URL http:// wWw. museudeartedorio.org.br/en/exhibitions/current?exp=1107 (2018-08-20).

Cava, Bruno (2013). A Multidão Foi ao Deserto: As Manifestações no Brasil em 2013 (Jun. a Out.). Rio de Janeiro: Annablume. 
Cava, Bruno; Cocco, Giulio (eds.) (2014). Amanhã Vai Ser Maior: O Levante da Multidão no Ano que Não Terminou. Rio de Janeiro: Annablume.

Celis, Karen et al. (2013). "Social Movement Organizations and Changing State Architectures: Comparing Women's Movement Organizing in Flanders and Scotland". Publius, 43(1), 44-67.

Comissão de Defesa dos Direitos Humanos e Cidadania da Alerj (2013). Relatório. Rio de Janeiro.

Confaloniere, Ulisse; Marinho, Diana (2007). "Saúde pública e risco social" [online]. "Rio - Próximos 100 Anos". A Cidade contra o Aquecimento Global, October 2007, Rio de Janeiro. URL http://portalgeo. rio.rj.gov.br/protocolo/pcontrole/documentos/saude_diana_1.Pdf (2018-08-20).

Coutinho, Roger et al. (2009). “Avaliação da Sustentabilidade Ambiental das Comunidades ante as Transformações Socioambientais Oriundas da Implantação do Complexo Portuário Industrial do Açu”. Boletim do Observatório Ambiental Alberto Ribeiro Lamego, 3(2), 11-22.

Cox, Wendell (2013). “The Evolving Urban Form: Rio de Janeiro” [online]. NewGeography.org. URL http://WWW. newgeography.com/content/003438the-evolving-urban-form-rio-de-janeiro (2018-08-20).

Dias, Alexandre Pessoa et al. (2013). “Complexo Petroquímico do Rio de Janeiro (Comperj): Impactos Socioambientais, Violação de Direitos e Conflitos na Baía de Guanabara”. Revista Ética e Filosofia Política, 1(16), 151-75.

Egler, Cláudio (2007). “O Rio de Janeiro e as Mudanças Climáticas Globais: Uma Visão Geoeconômica” [online]. "Rio - Próximos 100 Anos”, A Cidade contra o Aquecimento Global, October 2007, Rio de Janeiro. URL http: // WWw.egler.com.br/pdf/visao_geoeconomica_egler2_1.pdf (2018-0820).

Global Footprint Network (2015). National Footprint Accounts, 2015 Edition. Oakland: Global Footprint Network.

Gohn, Maria da Glória (2014). "A Sociedade Brasileira em Movimento: Vozes das Ruas e Seus Ecos Políticos e Sociais”. Cad. CRH, 27(71), 431-41.

Graeber, David (2004). Fragments for an Anarchist Anthropology. Chicago: Prickly Paradigm Press.

Guimarães, Roberta Sampaio (2014). A Utopia da Pequena África: Os Espaços do Patrimônio na Zona Portuária carioca. Rio de Janeiro: Editora FGW.

Guimarães, Virgínia Totti (2016). Direito à Cidade, Comuns Urbanos e Privatização de Espaços Públicos na Cidade do Rio de Janeiro: Os Casos da Marina da Glória e do Campo de Golfe Olímpico [PhD Thesis]. Rio de Janeiro: PUC.

Harvey, David (2001). Spaces of Capital: Towards a Critical Geography. Edinburgh: Edinburgh University Press. 
Harvey, David (2012). Rebel Cities: From the Right to the City to the Urban Revolution. London: Verso Books.

Herzog, Cecilia; Finotti, Ricardo (2013). “Local Assessment of Rio de Janeiro City: Two Case Studies of Urbanization Trends and Ecological Impacts". Elmqvist, Thomas et al., Urbanization, Biodiversity and Ecosystem Services: Challenges and Opportunities. Dordrecht: Springer, 609-28.

Instituto Políticas Alternativas para o Cone Sul (2012). Companhia Siderúrgica do Atlântico - TKCSA. Impactos e Irregularidades na Zona Oeste do Rio de Janeiro. Rio de Janeiro: Pacs.

IOC (2010). "Environmentally-Friendly Games" [online]. IOC News. URL https://www.olympic.org/news/environmentally-friendly-games (2018-12-11)..

Jacobi, Pedro (2003). “Movimento Ambientalista no Brasil. Representação Social e Complexidade da Articulação de Práticas Coletivas”. Ribeiro, Wagner Costa (ed.), Patrimônio Ambiental Brasileiro. São Paulo: Edusp/ Impresp, 519-43.

Klein, Naomi 2014. This Changes Everything: Capitalism vs. the Climate. New York: Simon and Schuster.

Larrea, Carlos; Warnars, Lavinia (2009). “Ecuador's Yasuni-ITT Initiative: Avoiding Emissions by Keeping Petroleum Underground". Energy for Sustainable Development, 13(3), 219-23.

Lopes, José Sérgio Leite (2006). “Sobre Processos de "Ambientalização" dos Conflitos e Sobre Dilemas da Participação”. Horizontes Antropológicos, 12(25), 31-64.

Lorenzi, Sabrina (2013). “Brazil Probe Seeks to Shut Down Thyssen's CSA Blast Furnace" [online]. Thomson Reuters, 18 January. URL https:// WWW.reuters.com/article/thyssenkrupp-brazil-csa-idUSL1E9CH2082 0130118 ? feedName=mergersNews\&feedType=RSS.

Maia, Luiz F.G. (2008). "Micro-clima e eventos climáticos extremos”. Gusmão Paolo Pereira et al., (eds.), Rio Próximos 100 anos - O Aquecimento Global e a Cidade. Instituto Pereira Passos; Prefeitura da Cidade do Rio de Janeiro: Rio de Janeiro, 130-42.

Martinez Alier, Joan (2005). El Ecologismo de los Pobres. Conflictos Ecológicos y Lenguajes de Valoración. Barcelona: Editorial Icaria.

Marx, Eric (2010). “The Fight for Yasuni”. Science, 330(6008), 1170-1.

Mascarenhas, Gilmar (2018). "Justiça Ambiental e Produção do Espaço nos jogos Rio 2016: O Paradoxo do Golfe Olimpico”. Geo UERJ, 32, 325-41.

Mascarenhas, Gilmar et al. (2017). “A Baía de Guanabara não é um Tema Olímpico". Revista Continentes, 10, 69-86.

McGranahan, G.; Satterthwaite, D. (2000). “Environmental Health or Ecological Sustainability? Reconciling the Brown and Breen Agendas in Urban Development”. Pugh, Cedric (ed.), Sustainable Cities in Developing Countries. London: Earthscan, 73-90. 
Melo, Gustavo Vaz et al. (2006). “Impactos do Processo de Urbanização sobre a Baía de Guanabara-RJ”. da Silva, Catia Antonia et al. (eds.), Metrópole: Governo, Sociedade e Território. Rio de Janeiro: DP \& A, 369-86.

Morris, Brian (2012). Pioneers of Ecological Humanism. Brighton: Book Guild Publishing.

Morris, Brian (2015). Anthropology, Ecology, and Anarchism: A Brian Morris Reader. Oakland: PM Press.

Moyses, Yana dos Santos (2010). “O Comperj: Modelo de Desenvolvimento Hegemônico e Contradições no Espaço Local (Itaboraí, Rio de Janeiro)”. Revista geografar, 5, 1-24.

Muehe, Dieter; Neves, Claudio (2007). "Impactos Potenciais da Mudanças Climáticas na Cidade do Rio de Janeiro e Possíveis Ações de Mitigação" [online]. "Rio - Próximos 100 Anos". A Cidade contra o Aquecimento Global, October 2007, Rio de Janeiro. URL http://portalgeo.rio.rj.gov.br/protocolo/pcontrole/documentos/zona_costeira_dieter_e_neves_1.Pdf.

O'Connor, James (1997). "What is environmental history? Why environmental history?". Capitalism Nature Socialism, 8(2), 3-29.

Oliveira, João Pacheco de; Cohn, Clarice (eds.) (2014). Belo Monte e a questão indígena. Brasília: Aba.

Partido Verde (2005). "Programa do Partido Verde” [online]. National Congress, Brazilia. URL http://pv.org.br/wp-content/uploads/2011/02/ programa_web.pdf.

Pato, Patricia Santiago (2010). “Implantação da Companhia Siderúrgica do Atlântico na Baía de Sepetiba-RJ". Revista Tamoios, 6(2), 54-62.

Pepper, David (2003). Eco-socialism: from Deep Ecology to Social Justice. London: Routledge.

Pickerill, Jenny; Chatterton, Paul (2006). “Notes Towards Autonomous Geographies: Creation, Resistance and Self-management as Survival Tactics". Progress in Human Geography, 30(6), 730-46.

Porto, Marcelo Firpo (2012). "Movements and the Network of Environmental Justice in Brazil". Environmental Justice, 5(2), 100-4.

Porto, Marcelo Firpo; Milanez, Bruno (2009). Parecer Técnico Sobre o Relatório de Impacto Ambiental da Usina da Companhia Siderúrgica do Atlântico (CSA). Rio de Janeiro: Fundação Oswaldo Cruz-FIOCRUZ.

Price, Andy (2012). Recovering Bookchin: Social Ecology and the Crisis of Our Time. Porsgrunn: New Compass.

Prumo (2010). Projects [online]. URL http://prumo.riweb.com.br/show.as pxidCanal $=J+n L+S 8 d B e U o I x U a w J y g Z g==\& l$ inguagem=en.

Quinto, Luiz de Pinedo et al. (2011). "Implantação de um Complexo Indus@ trial Portuário: O Caso do Porto do Açu”. Agenda social, 5(2), 84-103.

Rangel, Larissa Carneiro; Pessanha, Leonardo Ribeiro Moço (2014). “O Complexo Logístico Industrial Portuário do Açu e os Seus Impactos no Sistema de Drenagem e na Estruturação Urbana da Região Norte Flu- 
minense". Boletim do Observatório Ambiental Alberto Ribeiro Lamego, 7(2), 101-11.

Redclift, Michael (1987). Sustainable Development: Exploring the Contradictions. New York: Rutledge.

Richmond, Matthew Aaron; Garmany, Jeff (2016). "Post-Third-World City'or Neoliberal 'City of Exception'? Rio de Janeiro in the Olympic Era". International Journal of Urban and Regional Research, 40(3), 621-39.

Rio+Tóxico (2012). Rio+Toxico Tour 2012 [online]. URL http://riotoxico. hotglue.me.

Sader, Emir (ed.) (2013). Deis Anos de Governos Pós-neoliberais no Brasil: Lula e Dilma. São Paulo: Boitempo.

Shigetomi, Shinichi; Makino, Kumiko (eds.) (2009). Protest and Social Movements in the Developing World. London: Edward Elgar.

Shukaitis, Stevphen; Graeber, David (eds.) (2007). Constituent Imagination: Militant Investigations/collective Theorization. Oakland: AK Press.

Simonelli, Jeanne (2014). "Home Rule and Natural Gas Development in New York: Civil Fracking Rights". Journal of Political Ecology, 21(1), 258-78.

Souza Barreto, N.M.; Júnior, L.D.P.Q. (2013). “A (re) Produção do Espaço Capitalista nas áreas de Grandes Empreendimentos: Uma Análise Comparativa Entre os Conflitos Socioambientais nos Complexos Portuários do Açu e de Suape". Boletim do Observatório Ambiental Alberto Ribeiro Lamego, 6(1), 57-67.

Souza, Marcelo Lopes de (1999). O Desafio Metropolitano. Rio de Janeiro: Bertrand Brasil.

Souza, Marcelo Lopes de (2003). ABC do Desenvolvimento Urbano. Rio de Janeiro: Bertrand Brasil.

Steffen, Will et al. (2015). "Planetary Boundaries: Guiding Human Development on a Changing Planet". Science, 347(6223), 1259855.

Staudenmaier, Peter (2005). "Ambiguities of Animal Rights" [online]. Institute of Social Ecology, 1 January. URL http://www. social-ecology. org/2005/01/ambiguities-of-animal-rights/.

Turner, Graham (2014). Is Global Collapse Imminent? MSSI Research Paper, 4. Melbourne: Melbourne Sustainable Society Institute.

Venturini, Federico (2015). "Social Ecology and the Non-Western World". Network for an Alternative Quest (ed.), Challenging Capitalist Modernity II. Dissecting Capitalist Modernity - Building Democratic Confederalism. International Initiative Edition: Cologne, 118-24

Venturini, Federico (2016). A Critical Perspective on Social Ecology and Urban Crises: Learning about, with and from Urban Social Movements in Rio de Janeiro [Ph.D. thesis]. Leeds: University of Leeds.

Venturini, Federico (forthcoming). "The Value Of Social Ecological Theory in the Struggles to Come". Springer, Simon et al. (eds.), Anarchist Political Ecology. Oackland: PM Press. 



\author{
Through the Working Class \\ Ecology and Society Investigated Through the Lens of Labour \\ edited by Silvio Cristiano
}

\title{
Othered Bodies and Ecophobia Mamak Garbage Area
}

\author{
Zümre Gizem Yılmaz \\ (Hacettepe Üniversitesi, Ankara, Türkiye)
}

\begin{abstract}
This study aims to examine Mamak Garbage Area and the residents in that neighbourhood within ecophobic discourse in terms of analysing why and how they have become the target of ecophobic psyche. Garbage areas in general constitute elemental bodies combining natural elements and human influences since these areas are human-made natural storage yards. Moreover, junkyards reflect the relationship between human and nonhuman encounters. However, when disastrous results are experienced, human beings simply blame nature itself for the wrongdoings of the human practices. Furthermore, ecophobia is also targeted towards the human bodies residing in the garbage areas and depending on garbage for their living. Moreover, similar to wild nature, those human bodies are also excluded from the civil order, contributing to the discursive deep clash between nature and culture.
\end{abstract}

Keywords Ecophobia. Mamak Garbage Area. Garbage. Dirt. Nature vs Culture.

Roses, she thought sardonically. All trash, m'dear.

(Virginia Woolf, Mrs. Dalloway, 27)

Earth's history is full of records of destructive fiery agencies, the most striking examples of which, according to Hans H. Rudnick, vary from "the burning of the famous library of Alexandria to Hiroshima, Three Mile Island, and Chernobyl" (1988, 65). This contributes to the mystery surrounding fire with its both destructive and creative agential capacity. This perception of fire contributes to the ecophobic psyche in terms of "[i]magining badness in nature and marketing that imagination - in short, writing ecophobia" as Simon Estok underlines $(2011,5)$. This results from the fact that fire is an independent agency regardless of human perceptions. Nonetheless, in most of the cases, fiery agency prevails against human agency. In order to hear the catastrophic power of fire, Michel Serres has a suggestion: "Let's listen, there, to the screams of the Roman sailors that Archimedes burned, to the howls of Hiroshima's irradiated, whose torture the vanished Majorana no doubt wanted to avoid and present, or if not, delay; let's listen to the appeal sent out by Empedocles's vanished

Culture del lavoro 8 ISSN [online] 2610-9379| ISSN [print] 2610-8852

DOI 10.30687/978-88-6969-296-3/005 | Submitted: 2018-07-20 | Accepted: 2018-08-29

ISBN [ebook] 978-88-6969-296-3 | ISBN [print] 978-88-6969-297-0

(c) 2018 | (1) Creative Commons Attribution 4.0 International Public License 
body, amid Etna's deafening thunder and tall flames" $(2012,78)$. That is to say, although human history is marked by miraculous operations of fire in daily life, uncontrolled fire is hostile to human embodiment and habitat. Its incomprehensible agency has led fire to become an idol of uncontrolled power and solemnity. One example of uncontrolled fire displays itself in garbage areas with high risks of large scaled blasts. Consequently, garbage areas turn into direct reflections of ecophobic psyche as any human intervention is disregarded at times of garbage blasts, and the area itself is enunciated toxic and venomous. Along with the spatial labelling, residents are also taken out of the civilised order on the pretext of their toxic presences. In this framework, this study aims to explore ecophobic treatment against garbage areas and residents in that neighbourhood along with social and political enforcements onto the garbage pits.

Underlying this ecophobic perception is the discursive clash between matter and mind since anything other than human realm is accepted to be non-existent instruments ready for human service. The denial of the agency of matter automatically results in human beings' constant struggle to take the agency of nature under their control along with an attempt to tame nature in accordance with their own cultural norms and aesthetic appreciation. However, as Karen Barad also contends, "[m]atter is not little bits of nature, or a blank state, surface, or site passively awaiting signification" $(2009,139)$. Matter has an informational formation on its own independent from human agency. So, the superior status of human beings as the only knowledge-producer and unique subjects is shattered by pointing to the intrinsic meanings of matter. Matter has its own way of communication and information in its formation. For instance, John Fowles underscores the agential capacity of trees pointing to their biochemical formation to prevent a branch of another tree to occupy the other tree's space $(2000,25-6)$, which indicates their onto-epistemological formations without any human intervention. Furthermore, through the layers and roots of a tree, it is possible to read the history of that particular area where the tree stands. This illustrates that matter tells a story independent from human discourses.

On similar grounds, as an amalgam for storied matter coined by Serpil Oppermann and Serenella Iovino, garbage displays an agential activity since it clearly "carves life-forms out of" (McWhorter 1999, 167) its activity. So, garbage, as opposed to the general assumption, is not a passive or inert matter awaiting to be loaded up with meanings by humans. It, rather, constitutes its own meaning through a number of living beings inside its intrinsic material formation. In the toxic realm of our time, garbage is a mobile organism which also indicates its material influence over both the human body and the physical environment. It moves "with us on our shoes and bodies, [...] [is] moved by elemental forces like wind and water, and [...] [is] dispersed by mechanized means of travel" (Sullivan 2012, 516). 
In other words, garbage and dirt are found in our clothes, food, drink, and soil, hence carrying their own informational bodies everywhere through bodily intra-actions. Garbage is a subjective agenct. To acknowledge the subjective agency of nonhuman bodies leads us towards the question of agency as a whole. In this sense, the concept of agency has been revisited through new materialist and posthumanist perspectives challenging the superior position of human beings (implemented by humanism and Cartesian dualism) and human exceptionalism, hence questioning the ontological and epistemological categorisations of human and nonhuman beings. Stacy Alaimo draws attention to the fact that the recently revisited concept of agency has uncovered our rhizomatic relations in the physical realm stating that "we are permeable, emergent beings, reliant upon the others within and outside our porous borders" $(2010,156)$, hence hinting at the intermeshment of the environmental agency (matter) with the cultural realm (discourse). Defining the inevitable relation of the human to other beings such as animals, plants, matter, robotic bodies, elemental bodies, and inorganic bodies, the new definition of agency blurs and deconstructs the strict discrimination between the human and the nonhuman; matter and discourse. Agential capacity of the nonhuman, in this framework, "emerges from its intra-actions in a web of relations in which bodies and environments are co-constituted" (Alaimo 2010, 154). So, matter is not "a passive object of our linguistic creation" (Hekman 2008, 92). It has its own agency which cannot be reduced to the capacity of human conceptualization, and it has a unique capacity to act upon something and to be acted upon. With its agential power, matter creates its own echoes within the cosmic and earthly bodies, and creates various resoundings of its own form. That is to say, just as much as human is framed by nature and elemental forces, nature is framed by human agency, co-constituting a reciprocal formation. Material entities prove their agency in affecting the discursive formations of human societies, or vice versa, which underlines the intra-active process of becoming and emerging.

Similar storied agencies, garbage and dirt as subjective formations on their own tell their own story. The composition of garbage displays the fact that the agential potency of the elements is indomitable and prominent within the human lives. Yet, ignoring the fact that they are also composed of the same elements materially, human beings endeavour to patronise the four elements in the physical environments by trying to take them under the control of the human agency and domination. David Macauley hints at the human psyche noting that the "elements often appear dimmed down or diminished as they enter the human domus" (2010, 2). This is closely related to ecophobia which Simon Estok defines as "an irrational and groundless fear or hatred of the natural world, as present and subtle in our daily lives and literature as homophobia and racism and sexism" $(2011,4)$. Furthermore, along with fear and hatred, ecophobia also en- 
closes the control impulse of the human; nonetheless, "the more control we seem to have over the natural environment, the less we actually have" (Estok 2011, 5). Thus, the more the human tries to control the elements, the more catastrophic the results become. As regards, David Macauley further explicates that

pollution took the form of an assault on the elements as places and environmental conditions. Mining technologies and the timber industry in particular adversely affected air, earth, and water. The quest for mercury, lead, and arsenic - which contributed to bone, brain, and blood diseases - often caused streams to be redirected, dried up, or contaminated. The increasing removal of forests visibly scarred the landscape. Herodotus, for example, took note of the fact that an entire mountain was upended in search of gold. Emerging metallurgy emitted smoke and poisonous gases into the air in addition to the wood and charcoal burned as fuel. $(2010,128)$

Inasmuch as the agential acknowledgment of the elements as lively beings with potentials to act upon the human realm within the cosmos is to threaten the anthropocentric primacy of the human, the elements are targeted as the source of fear and hatred. Yet, this ecophobic hatred is located towards not only the physical environment but also the material body. Especially according to Renaissance philosophies, to appreciate spiritual beauty as well as intellective goodness, one has to avoid physical and bodily desires. This hatred is unwillingly exercised since the body is the allegedly restrictive and bounding factor for the exertion of rational ascent. The body becomes the bounding factor for the human beings because it is the only link for humans to the earth, which, consequently, constitutes their only material side. Jeffrey Cohen and Lowell Duckert point to the inhabitance of the cosmic elements within the body, which they describe as "temporary hosts for itinerant tales [which] are themselves elemental [;] every mind, soul, eye, or book a recording device to give local habitation as story proliferates, mutates, moves along. Our knowing the world is matter-mediated (enabled, impressed), an intimacy of substance, force, flesh, trope, plot, and weather" $(2015,11)$. Therefore, the body turns into the lens through which the physical environment can be experienced for a human being. The body, thus, becomes the principle nature and materiality for which human beings bear an inherent ecophobic impulse.

From another perspective, the allegation that the perfect soul is captivated and contaminated by the material body has always been inherent within Western philosophy and religion. Ken Hiltner draws attention to the fact that "Eve (like all human beings, imagined as a split amalgam of spirit and flesh) was portrayed as falling because she privileged the flesh while marginalizing the spirit" $(2014,86)$, portraying the interminable clash 
of body and mind (soul). In relation to this eternal clash, Thomas Kjeller Johansen furthers this discussion underscoring that

[b]odily illness is caused by the interference of the four elements and their derivatives within the body. Each element has a proper region in which parts of the same element are arranged together. When the elements go beyond their proper region they cause illness. Illness is seen as the result of unnatural acquisitiveness (pleonexia). [...] Timaeus goes on to explain how we can restore the elements within us to order (eis taxin) and prevent them from breeding wars (polemous) and diseases in the body by keeping the body in measured (metriōs) motion. When each element in the body is put next to a friendly element (philon para philon) physical health is restored. $(2004,20)$

Within this framework, this innate ecophobic impulse to have the ultimate control is inevitably directed towards body which is inevitably the key material point of exposure to the elements along with to the natural phenomena. Nevertheless, the unmediated exposure inevitably kills: "ask Robert Falcon Scott (found frozen in Antarctica, currently the coldest place in the world) or ' $49 \mathrm{er}^{1}$ Richard Culverwell (found desiccated in Death Valley, currently the hottest). Common deaths by exposure include hypothermia and dehydration, too little or too much fire" $(2015,13)$ state Lowell Duckert and Jeffrey Cohen. Henceforth, prevailing is the human-centred and ecophobic control impulse enacted specifically towards the elements which are the basic units through which humans can perceive the world. Moreover, the human body as a material substance is also composed of the natural elements, whereby it becomes the target of ecophobia, too. Therefore, just like the wild nature independent of human control, human body can also be converted into a source of ecophobia by the civilised human beings.

Interestingly though, human beings create their own untamed material-discursive formations which can be exemplified in garbage areas and junkyards. Garbage itself is an elemental embodiment, combining all the four main roots of the universe: water (with the generally chemical leaking water out of the garbage), earth (since they are dumped on the soil and mix with it forming different plant species), fire (with its explosion potential out of the squeezed methane gas) and air (because harmful gases are released). Formulating an elemental encounter on its own, garbage connects bodies. As a result, we all turn into "relatives by water, air, and dirt. Our bodies are made up of elements from the same piece of ground. Through

1 Editor's note: the 49ers, called after year 1849, were a group of pioneers exploring Californian harsh areas in the Gold Rush age (see for instance Wood 1980). 
endless cycles that dirt perpetuates itself. We arise from it and return, it circulates through these permeable membranes that individuate us temporarily" (McWhorter 1999, 173). However, separating themselves from this elemental enmeshment, human beings endeavour to take the material agency under their subjective control. However, although humans seem to tame nature through cultural dump areas and junkyards, ecophobic control impulse brings forth natural/cultural disasters for human beings; just like in the Ümraniye garbage explosion on 29 April 1993 in Istanbul, Turkey.

Random garbage dumping and covering garbage with soil in order to prevent the unpleasant smell results in squeezing garbage and dirt, and leaving it without oxygen, which consequently forms methane gas. The squeezed methane gas causes explosion. According to Şengüler and Yllmaz, the detrimental ecological effects of landfill gas sneaking out of garbage areas can be listed as follows:

- It is extremely insanitary for human [and nonhuman] health in terms of its potential toxic and partly carcinogenic substances.

- Coming up to \% 5-14 proportion in the air, methane gas concentration results in explosions, fires, and consequent loss of lives.

- Covering the roots of the plants, it interrupts their contact with the air.

- Some gases such as hydrogen and sulphide emit unpleasant smell.

- When covered with soil, the gases emanating in the unregulated storage areas cannot reach upper levels of the atmosphere, and start to move horizontally within the body of the garbage. These gases, therefore, get through permeable formations, cracks, and fractures towards the sewerage system and basements of the households, which, as a result, forms a very critical health problem for the residents of the city. $(1994,65)$

Ümraniye Explosion is an example of this formation as a result of which eleven houses and two garbage trucks were swallowed by the garbage blast (Gümüş 2014, 134). Apart from being a garbage area (pit) where all the garbage in the Anatolian side of İstanbul are gathered, Ümraniye is also home for garbage collectors (Nesin 1995, 64). Therefore, the explosion in Ümraniye is a human-made environmental and material catastrophe, and it has social and cultural dimensions as well. According to Miyase İlknur's report on Cumhuriyet (a popular Turkish newspaper) a year after this disaster, "although garbage is no more dumped in Ümraniye, people continue to live on this embarrassment area because of poverty: they even feed on herbs and vegetables growing out of the garbage area" (1994). Even though most of the houses in this slum area were destroyed and burned as a result of the explosion with lots of casualties, people still live there since this place offers cheap housing opportunities. Moreover, the underprivileged in that neighbourhood are also exposed to toxicity 
since they feed on the plants growing out of the contaminated soil in the garbage area. This validates McWhorter's statement on dirt that it "must be treated as a living thing that is cultivated and cared for just like the plant" $(1999,165)$. Miyase İlknur continues her report stating that "houses start again where the garbage area ends. At least five people still live in the houses damaged after the disaster. We are addressing Hacer grandma who is approaching towards us coming out of the door of a house which is about to collapse: 'Are you not afraid of living here?' 'Do we have any other choice? What good for us to be afraid? We do not have any other choice.' she answers" (1994).

Another example of a social problem out of poor housing opportunities in the slum areas near the junkyards is Mamak Garbage Area in Ankara, the capital city of Turkey. Mamak Garbarge Area is a place where approximately 3,500 tons of garbage all around Ankara are stored a day (Uğurlu, Pınar 2004, 14). To be more specific, Uğurlu and Pınar further explicate that

in Ankara-Mamak Dump Area, the waste and garbage of Ankara metropolitan arena have been dumped since 1978. The dump area is very vast both in terms of width and depth (its depth changes from 50 to 75 $\mathrm{m})$. In this area approximately 3500 tons of garbage are stored a day. And leaking water from this area mixes Imrahor Brook with a flow of 3.5 a second. $(2004,14)$

The hazardous chemical waste leaks out of this area and carries its toxic substance to İmrahor Brook, which in turn creates disease not only for human beings but also for nonhuman beings living in and around the brook. The location of the Mamak junkyard is very strategic in terms of its closeness to the water resources of the city. Tuzluçayır-Mamak unregulated garbage storage area is located in a very significant water basin: Imrahor Brook Basin. This basin is the southern channel passage of Ankara which is composed of a number of both ecological and recreational valleys (Dilek 2006, 331). The body of the contaminated area has an inevitable effect on other bodies, such as the body of the brook or that of the houses nearby.

Apart from shattering the ecological order, the garbage storage areas bring forth social problems as well. Since it is a risky environment to live in, housing is comparably cheaper; therefore, preferred by poor people. Nonetheless, this area grows within toxicity; henceforth, similar to the toxic body of the garbage, it causes human beings to sustain toxic bodies. In this sense, apart from substances and atomic particles of the garbage in this area, the junkyard also demonstrates the structure of society in Ankara, thereby it becomes the embodiment of both material (natural) and discursive (cultural) stories. In Miyase Ilknur's report on the Cumhuriyet, they inquire into the area that was affected by the fires in Ümraniye 
Garbage Explosion, and talks to Cemil Öztürk who lost his wife and his three children to the fires of the explosion: "Why did you get a house in the garbage area?" "Because the land was cheap there. Somebody had already parcelled that area, and was selling desperate people like us. I had no other choice. Who would know that the junkyard will explode? Did you know that?" (1994). This example exposes the failure of anthropocentric control drive which is the core of ecophobia. Although the junkyards seem to be controlled by the landowners and government authorities, to echo Simon Estok again, the more alleged control by human institutions result in the less actual control since material formations are unpredictable, and cannot be restricted to the limited human knowledge.

In relation to Mamak Garbage Area, "the historical process and spatial development of the area have been determined by a junkyard, from which the name of the district derived. In this sense, the spatial movement of the region followed the spatial movement of junkyard. Before the appearance of the initial gecekondus, ${ }^{2}$ this area in Mamak was the junkyard of Ankara" (Özuğurlu 2005, 45). Hence, that neighbourhood and all the bodies residing in that area are associated with garbage in one way or another. The ill-treatment of the storage yard leads to the disruption of the local ecology. As regards, Dilek underscores that "Tuzluçayır-Mamak Unregulated Storage Area occupies 30.9 hectare area, and maximum garbage density is up to 49 meters. It releases high ratios of ammonia nitrogen. Furthermore, the ratio of carbon monoxide is high above the limits" $(2006,324)$. Furthermore, Mamak garbage area, to continue Özuğurlu's observations,

covers 96 hectares and is composed of 2200 households, consists of different and hardly relevant geographical sites to some extent. Between the first settlement region in the early 70 s and the second one, there is the field of coal yard of Mamak, which was closed in 1997 and now is used for the animal sacrifice bazaar during the religious holiday (Kurban Bayramı [Sacrifice Holiday]). The third settlement, which was constructed on a rocky place, is nearer to Imrahor village and has quite distant relations with the neighbourhood because of the hill that was built by garbage. The fourth settlement, which was founded in the late 1980s is near to the new junkyard and is totally separated from the whole neighbourhood by the vehicle station of the municipality. $(2005,48)$

As the area is identified with slum areas and underprivileged residents, that area automatically turns into the target of ecophobia as a whole. Even mass-sacrifice of nonhuman animals as a part of the religious and cultural practices is executed next to the garbage area. As a result of this sacrifice

2 A Turkish slang used for the houses in the slum areas. 
practice, intra-action within animal parts, blood sacrificed and the local soil occurs, and this inevitably affects and, even, disrupts the local ecological environment. This negative intra-action adds another dimension in the toxifying capacity of the junkyard.

Similar to the Ümraniye garbage area, human beings residing in Mamak also become targets of ecophobia. In other words, both the area and bodies (especially human bodies) in it are feared and hated in terms of their potential toxic inclusivity. Greg Garrard underscores that "domination is implicated in discrimination and oppression on grounds of race, sexual orientation and class as well as species and gender" $(2004,26)$. Based on their class, in this case, human beings are marginalised and othered. They are further labelled as simply garbage collectors rather than citizens. Their lives are shaped by garbage; they feed on garbage; they earn from garbage. One example is Nurettin, whose story is told by Özuğurlu:

He was 5 years old when he migrated with his family from Sivas to Ankara in 1976. At third grade, he started to collect sponge and rubber from the Mamak junkyard, as his father did. Since then, in his words, he "did not get out of the garbage." He is 32 years old even though the garbage "wore him down, made him older." He is married and has two children. Up to now, he has had no insurance. His only desire is to keep his children away from garbage collection, which he inherited from his father. $(2005,139)$

The lives of the garbage collectors are so garbage-layered that the soil thickness covering the garbage at times descends down to one or two centimetres; therefore, in the gardens of some houses, trashes can be encountered as they circulate beneath the earth, and most of the houses are filled with bad smell (Dilek 2006, 324). Within this framework, human beings and the environment they reside in are intertwined, as a result of which nature (though changed by human practices) and local culture (though changed by certain material formations) have reciprocal effects on each other.

In this vein, the garbage area itself is a porous body where culture (discourse) and nature (matter) meet. The junk-yard, in Nurettin's words, "receives from Çankaya (a wealthy area in Ankara) 'parlak-mallı çöp' (luxury garbage), but from gecekondus 'küllü-pis çöp' (dusty garbage). [...] No need for metaphors, looking from the junkyard may inform us about class inequalities and may provide us a critical insight about the centrality of consumption to modern capitalism" (Özuğurlu 2005, 139). As Çankaya is a wealthy neighborhood in Ankara, their garbage is totally different from Keçiören's which is an area not as wealthy as Çankaya. This shows the class structure of society, concluded from the reality of the garbage area. Hence, dirt and garbage in this junkyard tell the story of a metropolitan 
city where the financial gap between the poor and the rich is observed. Moreover, othered and marginalised within the social system of metropolitan civilisation, a garbage collector tells the story of the city simply by looking at the material presence and agency of the junkyard.

On the other hand, the government and the municipal corporation have recently decided to construct a recycling facility in the place of the openair junkyard. This has revealed "capitalist consumerism that transforms matter into commodities" (Alaimo 2010,147) on the one hand, and created another social dilemma on the other, and turned into a housing problem since people living in the slum areas have been left without their houses. In this regard, Garrard contends that "[e]nvironmental problems cannot be clearly divorced from things more usually defined as social problems such as poor housing or lack of clean water" (2004, 29), hence correlating an "association of acute environmental degradation and pollution with poverty" (2004, 29). On similar grounds, T.V. Reed points out that "for decades the worst forms of environmental degradation have been enabled by governmental and corporate policies of dumping problems on communities of color, poor whites, and the Third World" $(2002,146)$. In this sense, the Mamak Junkyard and the inhabitants in that area are examples for the othering process out of ecophobic psyche in the civilised order. Furthermore, the fact that a part of the land of this junkyard has been recently converted into a big shopping centre (Nata Vega AVM) underlines the commercial impositions of big corporations onto such environmental problems. Moreover, this conversion hints at the ecophobic psyche urging people to fit the physical environment into cultural and civilised human order. This former desolated and untamed environment is seized to be under human control, and allegedly saved to be a part of human civilisation with its own capitalist symbol of a shopping centre. However, as a result of this conversion of the land, housing problems have occurred for the inhabitants, whereby their toxic and othered bodies have been discarded from the civilised order, which consecutively functions as a relief for the civilised residents living in the city far from the garbage pits because it proves the fact that environmental and related social problems are things "that happen [...] only to others, to lower-class people in ghettos or inner cities or squalid Third World villages" (Reed 2002, 151). The control attempt of the garbage area, which is itself a subjective and unique elemental body, erases the irrational fear and hatred towards the area on the surface as the polished newly-organised area fits into the metropolitan facet of the capital city with capitalist representatives on the land (shopping centre and governmental facility). Yet, garbage collectors are still the source of ecophobia in society, without proper housing this time.

Although created by human practices and discourses, such toxic environments as Mamak Garbage Area are easily targeted for ecophobic psyche of the humans. The disastrous consequences of toxicity spread- 
ing out of these garbage areas are direct results of human misuse and ill-treatment because natural catastrophes generally stem from humans' anthropocentric drive to tame and control the physical environment, and to adopt nature into their own discourses and practices. Nonetheless, the chaos growing especially out of garbage areas hints at the failure of human-centred perspective since the more the humans interfere with the intrinsic material formations in the physical environments, the more chaotic the results become. Yet, the failure of human attempt to control is discursively associated with nature's uncivilised and untamed qualities. Henceforth, as nature itself is illustrated as the source of all these evil and catastrophic chaos leading even towards the loss of human lives, ecophobia prevails in the human psyche. In order to eradicate chaotic conflicts allegedly between human and nonhuman spheres, rather than resetting nature within a human framework with pointless attempts to domesticate, we must find out to live in accordance with the natural and material formations. But first, we should acknowledge that we are part of this material world, and along with human existence, nonhuman beings and matter also have intrinsic value and agential capacity. They tell their own stories regardless of the discursive impositions by the human domain.

\section{Bibliography}

Alaimo, Stacy (2010). Bodily Natures: Science, Environment, and the Material Self. Bloomington: Indiana University Press.

Barad, Karen (2009). "Posthumanist Performativity: Toward an Understanding of How Matter Comes to Matter". Alaimo, Stacy; Hekman, Susan (eds.), Material Feminisms. Bloomington: Indiana University Press, 120-54.

Cohen, Jeffrey Jerome; Duckert, Lowell (2015). “Introduction: Eleven Principles of the Elements". Cohen, Jeffrey Jerome; Duckert, Lowell (eds.), Elemental Ecocriticism: Thinking with Earth, Air, Water, and Fire. Minneapolis: University of Minnesota Press, 1-26.

Dilek, Figen E (2006). “Tuzluçayır-Mamak Düzensiz Depolama Alanı için Peyzaj Onarımının Önemi ve Gereği”. Tarım Bilimleri Dergisi, 12(4), 323-32.

Estok, Simon (2011). Ecocriticism and Shakespeare: Reading Ecophobia. New York: Palgrave Macmillan.

Fowles, John (2000). The Tree. London: Vintage.

Grinderud, Knut; Rasmussen, Haakon; Nilsen, Steinar; Lillethun, Arvid; Holten, Atle; Sanderud, Oystein (eds.) (2009). GIS: The Geographic Language of Our Age. Trondheim: Tapir Academic Press.

Garrard, Greg (2004). Ecocriticism. New York: Routledge. 
Gümüş, Naci (2014). Gün Batmadan: Hayat, Hatıra ve Hayal. İstanbul: Sam Yayınları.

Hekman, Susan (2008). "Constructing the Ballast: An Ontology for Feminism”. Alaimo, Stacy; Hekman, Susan (eds.), Material Feminisms. Bloomington: Indiana University Press, 85-119.

Hiltner, Ken (2014). “Early Modern Ecocriticism”. Cefaule, Paul; Kuchar, Gary; Reynolds, Bryan (eds.), The Return of Theory in Early Modern English Studies. London: Palgrave Macmillan, 81-94.

İlknur, Miyase (1994). “Ümraniye Çöp Felaketinin Yıldönümünde, Verilen Sözler de Unutuldu” [online]. Cumhuriyet. URL http://earsiv.sehir. edu.tr (2017-06-02).

Iovino, Serenella; Oppermann, Serpil (2012). "Theorizing Material Ecocriticism: A Diptych". Interdisciplinary Studies in Literature and Environment, 19(3), 448-75.

Johansen, Thomas Kjeller (2004). Plato's Natural Philosophy. Cambridge: Cambridge University Press.

Macauley, David (2010). Elemental Philosophy: Earth, Air, Fire, and Water as Environmental Ideas. Albany: State University of New York Press.

McWhorter, Ladelle (1999). Bodies and Pleasures: Foucault and the Politics of Sexual Normalization. Bloomington: Indiana University Press.

Nesin, Aziz (1995). Çuvala Doldurulmuş Kediler: Yazllar. İstanbul: Adam Yayınları.

Özuğurlu, Aynur (2005). Poverty or Social Reproduction of Labour: Life in Çöplük District [PhD Dissertation]. Ankara: Middle East Technical University.

Reed, T.V. (2002). “Toward an Environmental Justice Ecocriticism”. Adamson, Joni; Evans, Mei Mei; Stein, Rachel (eds.), The Environmental Justice Reader: Politics, Poetics and Pedagogy. Tucson: University of Arizona Press.

Rudnick, Hans H. (1988). “Fire in Goethe's Work: Neptunism and Volcanism". Tymieniecka, Anna-Teresa (ed.), Poetics of the Elements in the Human Condition: The Airy Elements in Poetic Imagination, Breath, Breeze, Wind, Tempest, Thunder, Snow, Flame, Fire, Volcano.... Berlin: Springer Science, 65-71.

Şengüler, İlker; Yılmaz, Bazım (1994). “Çöp Depolama: Çöp Depolama Alanlarında Oluşan Gazın (Deponi Gazı) Çevresel Etkileri Ve Ekonomik Potansiyeli (The Environmental Impacts and Economic Potential of the Gas (Deponi Gas) Formed in Waste Disposal Sites)" [online]. Jeoloji Mühendisliği Dergisi, 44-5, 62-66. URL http://www.jmo.org.tr (2017-06-03).

Serres, Michel (2012). Biogea. Minneapolis: Univocal.

Sullivan, Heather I. (2012). "Dirt Theory and Material Ecocriticism”. Interdisciplinary Studies in Literature and Environment, 19(3), 515-31. 
Uğurlu, Ayşenur; Aytunç Pınar (2004). "Doğal Zeolitlerin Atıksu Arıtımında Kullanımı" [online]. Jeoloji Mühendisliği Dergisi, 28(2), 1320. URL http://www.jmo.org.tr (2017-06-03).

Wood, Raymund F. (1980). "Death Valley '49ers" [Review]. Southern California Quarterly, 62(1), 104-6.

Woolf, Virginia (2013). Mrs. Dalloway. Wallace, Jo-Ann (ed.), Toronto: Broadview Editions. 



\title{
Through the Working Class
}

Ecology and Society Investigated Through the Lens of Labour

edited by Silvio Cristiano

\section{Turning Modernity Upside Down \\ La Belle Verte, Island and the Making of Non-capitalist Ecologies}

\author{
Rocio Hiraldo Lopez-Alonso \\ (University of East Anglia, Norwich, UK)
}

\begin{abstract}
Through a contrast between primitivist classless utopias and the modern world, Coline Serreau's film La Belle Verte and Aldous Huxley's book Island suggest modern 'progress' obstructs the creation of healthier relations with our own bodies, with other humans and non-human nature, and how self-sufficiency, voluntary austerity and non-hierarchical mutual aid relations produce the opposite effect. Ensuring environmental protection and human freedom in non-capitalist ecologies will involve the rejection of (and the creation of alternatives to) the pillars of Western modernity.
\end{abstract}

Summary 1. Introduction. - 2 Alternatives to Modernity, Alternatives to Alienation: La Belle Verte and Island. - 3 Conclusion.

Keywords Western modernity. Non-capitalist ecologies. Ecomodernist socialism. Primitivist utopias. Alienation from species-being.

\section{Introduction}

Modernity is increasingly being questioned in debates around ecosocialism and post/non-capitalist ecologies. Recently, several scholars and activists have critiqued ecomodernist socialism and fully automated communism for failing to seriously consider the ecological and class implications of technology-driven progress, and for preventing ecofeminist critiques to penetrate in these imaginaries of change (Angus 2017, Barca 2018, Vansintjan 2018). In line with these efforts I would like to reflect here on Coline Serreau's film La Belle Verte and Aldous Huxley's book Island, which have the virtue of showing the various ways in which modern 'progress' obstructs the process of establishing healthier relations with our own bodies, with other humans and non-human nature. By imagining primitivist classless utopias and critically examining everyday life in modern societies, they show that modernity alienates humans from what Marx (1959, 31-2) called "species-being", artificially separating us from our belonging to a greater (human and non-human) whole.

Culture del lavoro 8 ISSN [online] 2610-9379 | ISSN [print] 2610-8852

DOI 10.14277/978-88-6969-296-3/006 | Submitted: 2018-07-20 | Accepted: 2018-08-24

ISBN [ebook] 978-88-6969-296-3 | ISBN [print] 978-88-6969-297-0

(c) 2018 | () (i) Creative Commons Attribution 4.0 International Public License 
Island tells the story of Will Farnaby, a British journalist who accidentally arrives on the island of Pala, where Buddhist philosophy and "primitive communism" form the basis of social and ecological relations. His visit to this island entails both, the discovery of a new society and an encounter with modernity through the critical eyes of Palanese people. La Belle Verte takes its name from a utopian planet where anarchy is the basis of human relations and the modernist ideal of progress is inversed. Its inhabitants define the industrial era as "competition, mass production of useless objects, wars, nuclear technology, diseases without cures, in sum, a prehistoric period!". The film tells the story of a BelleVertian woman called Milá in her visit to Paris, where she often "disconnects" earthlings from modern consciousness, making them mentally advance 500 years.

\section{Alternatives to Modernity, Alternatives to Alienation: La Belle Verte and Island}

La Belle Verte and Island expose the unhealthy social and ecological relations upon which modern capitalist societies are based and propose nonalienating ways of relating to our bodies, to other humans and non-human nature within and outside the realm of material production.

Contrary to the ecosocialist modernist and fully automated communist ideals, in these two utopias wellbeing and environmental protection equal self-sufficient, austere and 'primitive' lifestyles. Central in BelleVertians and Palanese people's healthy relationship with non-human nature is the fact that they are proud manual labourers who produce what they eat and obtain their needs by transforming nature (and hence polluting) as little as possible. In La Belle Verte everyone is a farmer and people offer their surplus production to others in annual planetary meetings. They also decide collectively the number of pregnant women based on the harvest. BelleVertians do not have beds, they sleep on the grass, in a sort of straw nests. They bathe in lakes and their education and leisure require few objects. This lifestyle emerged after a period where those making business with damaging products were judged as culprits of genocide and crimes against the planet. Targets included key pillars of contemporary capitalist economies: food and chemical industries, weapon, tobacco, alcohol, pharmaceutical and nuclear companies, car producers as well as architects, doctors and politicians who got rich by allowing these companies to exist and expand. Afterwards there was a boycott period where people stopped buying all their technological devices or threw away them because of their negative health and ecological consequences.

In Pala people feel the resources they have in their island are enough for them and refuse to extract oil and earn money by exporting it. Their respect for nature is associated to a broader culture that connects Pala- 
nese people with the rest of the universe while acknowledging individual diversity:

adolescents are helped to experience their transcendental unity with all other sentient beings and at the same time they're learning, in their psychology and physiology classes, that each one of us (not only humans) has his own constitutional uniqueness, everybody's different from everybody else (202).

Such holistic consciousness emphasises humans' belonging to a greater whole and therefore individuals' responsibility within society formation:

We teach children love and confidence, but...they're made to understand that Pala isn't Eden. It's a nice place all right. But it will remain nice if everybody works and behaves decently (191).

This perspective makes unnecessary the use of police methods in the maintenance of communitarian relations. This is why Palanese people define communism as 'voluntary associations of men and women on the road to full humanity' (171). Similarly, for BelleVertians it is nobody and, at the same time, everybody, who rules their planet. They relate to each other in egalitarian and gentle ways, and feel sorry for earthlings' superiority complex and reliance on hierarchies:

I hope that in 200 years they (Earthlings) have had the time to get rid of hierarchy./ Ah, no, hierarchy over there is something. All bosses, all of them believe to be superior to something else: men think they're superior to women, the people from the city to the people from the villages, adults are better than the children, human beings are superior to animals and plants, and then there are the races!

Serreau also shows how alienation from human and non-human nature is reproduced through space, and particularly urban space. During her first strolls in Paris, Milá is surprised by Parisians' bad mood and lack of empathy, by the lack of rivers in Paris, the predominance of concrete over grass, the abundance of dog excrements on the streets and Parisians' tolerance to high air pollution levels.

Through this and other examples, Serreau and Huxley defetishise key cultural elements and symbols of progress in modern Western societies, such as medicine, music, sport, academia and the cult of beauty as well as the work relations within them. They do so by exposing the close line between perfectionism and emotional repression in these contexts through the objectification of human beings in these contexts. In La Belle Verte 'disconnected' football start hugging and dancing with members of the 
opposing team in the middle of a match. 'Disconnected' musicians break the order of a classical music concert, jumping on their chairs, dancing, improvising lyrics and playing other music styles. A dialogue between Milá and a woman who explains her reasons for using lipstick Serreau also exposes how women are pressured to be attractive to everybody in modern societies:

and what is this for? (Milá, hereafter M) / It is to put it on your lips (Parisian woman, hereafter $\mathrm{Pw}$ ) /Is it a medicine? (M)/ No, it's to be pretty $(\mathrm{Pw}) /$ Pretty? (M) /To be sexy (Pw) /Sexy? (M)/Yes, to be attractive (Pw)/ Oh, to whom? (M)/To everybody (Pw)/It must be difficult to do this... oh I see, it's a medicine so that everybody loves you, is that right?... and if you don't wear it, nobody will love you. Is that right? (M)/ It's difficult to explain $(\mathrm{Pw}) .$. (the woman becomes sad).

Huxley questions Western medicine through Palanese people's eyes, who define it as "50 per cent terrific and 50 per cent inexistent" because it focuses on cure "but has no methods for increasing resistance" (67). In contrast, Palanese medicine is preventative and raises awareness about the patient's relation to her own body. Therefore, rather than diagnosing the problem, doctors' role is to keep people physically and emotionally well. Palanese medicine is therefore about teaching people the way of going through life. It provides answers about the food people eat, about the way in which they make love, what they see and hear and about their feelings for being in the world.

Through a Palanese person's description of his encounters with academics in Cambridge, Huxley shows the paradox between Western education's emphasis on knowledge and its ignorance of human bodies' rhythms and needs:

I was thinking of two people I met when I was at Cambridge. One of them was an atomist physicist and the other was a philosopher. Both extremely eminent. But one had a mental age outside the laboratory, of about eleven and the other was a compulsive eater with a weight problem he refused to face. Two extreme examples of what happens when you take a clever boy, give him 15 years of the most intensive formal education and totally neglect to do anything for the mind-body related with the learning and the living (208).

In contrast, BelleVertians and Palanese people are emotionally wise and practise physical as well as mental exercise everyday. They are encouraged to exercise their bodies through work and games, and are provided with mechanisms to know their bodies better so to use them more efficiently (not for the profit of somebody else, as in capitalist production, but for their 
own benefit). The following dialogue between Will, the British journalist, and a Palanese doctor illustrates this idea:

So you take digging and delving as a form of therapy? (W)/As prevention. In Pala even a professor puts in two hours of digging and delving each day. (PD) /As part of his duties? (W) /And as part of his pleasure (PD)/ It wouldn't be part of my pleasure... I take children get this kind of training (W)/ From the first moment they start doing for themselves... by the time they are fourteen they have learned how to get the most and the best out of any activity they undertake. And that's when they start working. Ninety minutes a day at some kind of manual job' (PD) (143).

In line with contemporary indigenous and feminist movements, Huxley and Serreau see advanced societies as those where kindness and affection are a central element of everyday social and ecological relations. In the following paragraph a woman shares Palanese peoples' techniques foe treatin babies with Will Farnaby:

Stroke the baby while you're feeding him; it doubles his pleasure...Then, while he's sucking and being caressed, introduce him to the animal or person you want him to love. Rub his body against theirs. Food plus caress plus contact plus good equals love. And love equals pleasure, equals satisfaction (189-90).

Similarly, Serreau equals human progress to kindness and curiosity. When Milá 'disconnects' the head of an obstetric unit of a Parisian hospital, he changes the way he relates to others at work. He stops being authoritarian, starts relating to his colleagues in affectionate and non-hierarchical ways, and confesses his ignorance about deliveries to a mid-wife, who is below him in the labour hierarchy. Unafraid of his lack of knowledge about the subject and enthusiastic about learning, he starts asking a postpartum woman about her experience of delivering a baby.

In these utopias progress also means better ability to pay attention to ourselves and to our non-selves, hence better ability to notice the importance of and beauty in other humans and non-human nature. In Island, Palanese birds constantly tell Will the word 'attention' and in La Belle Verte after being disconnected from modern consciousness, the obstetrician starts admiring his colleague's curly hair; a Parisian woman becomes deeply interested in the shapes of a lettuce leaf; and a man who had just become irritated after having received a minor dent in his car starts hugging trees and people while thanking them. 


\section{Conclusion}

Technologies symbolise human progress and wellbeing, and so do cities, petrochemicals, western medicine and academia. But, do modernist approaches to ecosocialism really consider the social, environmental and emotional costs of that which represents modernity? Huxley's and Serreau's reply to this question would be "no, they do not". I fully concur with them. The basis for dreaming and building healthier socio-ecological systems are relations: healthier and more conscious relations with our own bodies, with other humans and with non-human nature. This means defetishising capital and everything that represents advancement in the Western world today. More importantly, it means conceiving ourselves holistically within and beyond the sphere of material production, making care a central aspect of our social and ecological relations. As Island and La Belle Verte show, this 're-connection' to the greater (human and non-human) whole to which we belong will not fully take place unless we refuse to key elements of modernity such as technologies, hierarchies and consumerism and we voluntarily adopt communitarian economic systems based upon an even distribution of work.

\section{References}

Angus, Ian. (2017). "Memo to Jacobin: Ecomodernism is not ecosocialism" [online]. URL http://climateandcapitalism.com/2017/09/25/memo-tojacobin-ecomodernism-is-not-ecosocialism/ (2018-03-12).

Barca, Stefania (2018). "The Jacobin's eco-modernist dilemma” [online]. URL https://entitleblog.org/2018/02/08/the-jacobins-eco-modernist-dilemma/ (2018-02-20).

Huxley, Aldus. (2005). Island. London: Vintage Books

Marx, Karl [1844] (1959). Economic and Philosophical Manuscripts. Moscow: Progress publishers.

Vansintjan, Aaron. (2018). "The shitty new communist futurism” [online]. URL https://entitleblog.org/2018/01/25/the-shitty-new-communistfuturism/ (2018-03-02). 


\title{
Literary Representations of Human-Nonhuman Labour Collaborations
}

\author{
Fatma Aykanat \\ (Zonguldak Bülent Ecevit Üniversitesi, Zonguldak, Türkiye)
}

\begin{abstract}
The Anthropocene refers to a geological time interval triggered by the human activities on Earth, and proposes humans as geological forces changing the ecosystems irreversibly. However, human activities, such as industrialization, overpopulation, extreme consumption habits, and exploitation of natural resources put pressure on our planet's sustainability. Thus, these human induced stressors on the environment pose a threat for all biological species inhabiting the Earth, both human and nonhuman. Industrialization is one of the suggested starting points of the Anthropocene epoch. Taking industrialisation, which started to accelerate in the late eighteenth and early Nineteenth centuries, and the transition from wood to fossil fuels like coal to meet the need for energy during the industrialization process as its primary focus, this article explores how the efforts of industrialisation effect socio-cultural life and the relations of human and nonhuman agents nearby. Portraying the entangled lives of the coal miners and their nonhuman helpers, miner mules, in a newly developing mining town in the Nineteenth century Turkey, Zonguldak, this study opens to discussion or consideration various issues related to the working class environmentalism and the nonhuman labour. For illustrative purposes, various literary texts written in this period, such as Turkish novelist Mehmet Şeyda's Yanartaş [The Burning Stone] and poems by Turkish poets like Orhan Veli Kanık and Rıfat Ilgaz, will be referred.
\end{abstract}

Keywords Anthropocene. Working class environmentalism. Nonhuman labour. Coal mines. Miner mules. Zonguldak. Turkey.

The preliminary readings and researches on the starting point of the Anthropocene, and the events triggering such a huge, global-scale anthropogenic change in the geological timeline of the Earth, as the Anthropocene hypothesis suggests, necessitate putting certain periods and major turning points of human civilisation under the spotlight and examine them in a more detailed way. One of these turning points was the Industrial Revolution in which the growing need for more effective energy sources to meet the requirements of the rapid industrialisation in Europe in the Nineteenth century. Thus, with the radical change of global energy regimes towards a fossil-fuel-driven industrial production that it hosts, the Nineteenth century is proposed by many environmental historians and natural scientists, including Paul Crutzen and Eugene Stoermer, the Earth scientists who coined the term 'Anthropocene' in 2000 for the first time, and environmental historian Dipesh Chakrabarty, who underlined "the

Culture del lavoro 8 ISSN [online] 2610-9379| ISSN [print] 2610-8852

DOI 10.30687/978-88-6969-296-3/007 | Submitted: 2018-07-20 | Accepted: 2018-08-31

ISBN [ebook] 978-88-6969-296-3 | ISBN [print] 978-88-6969-297-0

(c) 2018 | (1) Creative Commons Attribution 4.0 International Public License 
collision" of Earth geological history and humans's social history, as the starting point of the Anthropocene. Especially Chakrabarty's emphasis is on the "collective identity" (2009, 197-200) of humans as yet another biological species repositions humans in their nonhuman environments, and requires reconsidering the relationship of humans with their nonhuman environment. Thus, within the framework of labour, this study aims to explore the connections between human and nonhuman labour forces and their collaborative entanglements during the Nineteenth century industrialisation process, which is proposed as one the starting points of the Anthropocene.

The start of the Anthropocene epoch is still a controversial issue. Although the latest (2018), and unanimously agreed official report of "the Anthropocene Working Group", which has been assigned in 2008 to make a thorough research on the validity of the Anthropocene hypothesis by The International Commission on Stratigraphy, which is the only authorised institution to officially confirm any geological change in the geological timeline of the Earth, like the entrance in the Anthropocene, marks the second half of the Twentieth century as the beginning of the Anthropocene due to the nuclear prints in the stratigraphic samples, there are also other views ("Media Note: Anthropocene Working Group" 2016). For the periodisation of the Anthropocene and the global-scale environmental transformations it entails, some scholars like environmental historian Dipesh Chakrabarty pinpoint earlier periods as the beginning of the Anthropocene as J.R. McNeill and Peter Engelke propose a more recent date for the Anthropocene and mark the second half of the Twentieth century as a critical period for human-induced environmental transformations. Chakrabarty argues that anthropogenic environmental changes date further back when humans abandoned hunter-gatherer lifestyles for long-term settlements, and hence marks "the beginnings of agriculture, the founding of cities, the rise of religions" (2009, 208-9) as major turning points causing our planet to enter a new geological period. On the other hand, according to McNeill and Engelke, it is especially in "the post-Second-World-War period, especially from the 1950s onwards" $(2014,4)$ the volume and frequency of human intervention into the planetary biological cycles increased. Humans' engagement with nuclear energy in the 50s and 60s led to nuclear prints of plutonium and uranium after the testing of nuclear warheads as well as nuclear bombings.

Despite various contesting views pointing to different historical periods as its beginning, the Nineteenth century still stands as an important period marking the beginning of human-induced environmental changes. The originators of the Anthropocene concept, Crutzen and Stoermer mark the 1800 s, referring to James Watt's improvements on the first steam engine in 1784, as the beginning of the Anthropocene, and argue that it is the modern technology that initiated the transformation of Earth-system be- 
haviour and changed environmental processes: "To assign a more specific date to the onset of the Anthropocene seems somewhat arbitrary, but we propose the latter part of the Eighteenth century, although we are aware that alternative proposals can be made" (Crutzen, Stoermer 2000, 17). Crutzen and Stoermer offer the term Anthropocene for the time interval dominated by human activities and indicate that the onset of the human ability to significantly shape the Earth's environment became notable with the Industrial Revolution:

The Anthropocene could be said to have started in the latter part of the eighteenth century, when analyses of air trapped in polar ice showed the beginning of growing global concentrations of carbon dioxide and methane. This date also happens to coincide with James Watt's design of the steam engine in 1784. (Crutzen 2002, 23)

The invention of steam engine was ground breaking because it allowed carbon dioxide to be reintroduced into the present carbon cycle. By this way, it accelerated the increase in the atmospheric carbon dioxide concentrations, and radically, maybe irreversibly, altered the atmospheric structure. So, in the late Eighteenth century, the use of coal that helped the British economy flourish, gradually triggered the fossil fuel use worldwide making coal replace biomass turn out to be the major requirement of the industrial pursuits in a very short time. Thus, the late Eighteenth century and the early Nineteenth centuries can be marked as crucial periods in which the global energy regime changed towards highly demanded fossil fuels like coal. Similar to Crutzen and Stoermer, as the period marking the beginning of contemporary environmental problems, environmental scholar Andreas Malm also blames industrialisation triggered by the invention steam engine, and the global capitalist aspirations that follow this crucial invention. Malm describes the fossil economy as "a socio-ecological structure, in which a certain economical process and a certain form of energy are welded together" $(2016,39)$. So, the close connection between economic processes and their long-term socio-economic consequences are undeniable. However, shadowed by capitalist aspirations, these possible negative outcomes have been neglected, and heavy industrialisation process rapidly spread all around Europe.

In parallel with the industrialisation in European countries, Nineteenth century was also a period of increasing industrial activities and the need for domestic energy sources in the Ottoman Empire, which will evolve into the Republic of Turkey in the following century. Zonguldak is one of the most important industrial cities in Turkey, which is socially, economically and geo-morphologically shaped by the discovery of coal reserves in the Nineteenth century and by the mining activities following this discovery. Thus, this paper spotlights on Zonguldak to discuss the role of collective 
human activities, such as industrialisation and rapid industrial production as well as urbanisation, increase in population in and around the mining areas, through exemplary local accounts from the residents of Zonguldak. By this way, this paper aims to explore a global issue, environmental changes induced by anthropogenic industrial activities, through a local lens. I believe that, as Chakrabarty suggests, a historical 'collision' of the human history and the environmental history arguing that the stories of 'our human lives' need to be supplemented by the stories of 'our collective lives as a species' $(2009,49)$. Thus, I aim to explore the formation of the story of coal and the story of a city, Zonguldak, together.

Zonguldak is a small coastal city located in the Blacksea region of Turkey, and it hosts the first known, and the richest coal reserves in Turkey. Supposedly, the first samples of coal in Zonguldak were accidentally discovered by a local marine named Uzun Mehmet in November, 1829. Yet, the first establishments of private corporations supported by foreign capitals in the Zonguldak coalfields under Ottoman rule date back to 19 years after the first discovery of coal within Ottoman Empire's borders, and these coalfields began to be run by the state, later the Republic of Turkey, no sooner than 1937. After such a slow and chaotic beginning, coal is located at the heart of the life in Zonguldak turning this small coastal town gradually into the leading mining city in Turkey. The industrial transformation of Zonguldak was accelerated especially in the post-Second World War period.

To look back into years when the first discovery of coal in Turkey, one needs to examine the Nineteenth century Ottoman Empire. In the early Nineteenth century, first, the Ottoman Sultan Mahmut II, and then Sultan Abdulmajid II realised the increasing demand for fuel by the Ottoman Navy, especially in military ship-building yards, as well as by the newly established factories and workshops. At the beginning, this demand had been met by burning coal. In the absence of any known natural coal reserves within the borders of the Ottoman Empire, the huge amount of coal needed for domestic industrial and military uses was being imported from other European countries, such as Britain and France. Yet, these import activities were becoming more and more costly for the Ottoman Empire. So, in order to provide a domestic alternative, upon the advise of some farsighted senior mariners, Ottoman Sultan Mahmut II gives orders for a thorough investigation of possible coal reserves within national borders. However, the majority of the common people in the country had no clear idea of how coal looks like. Thus, taken the fact that they had a change to see coal, which was burned in the boiler rooms of their ships, the first unofficial investigators of coal were the Ottoman mariners. They were recommended by their superiors to keep their eyes open for such possibly burning stones during their vocational leaves that they would spend in their hometowns. This idea actually worked, and it is supposed that the first samples of coal in Zonguldak were discovered accidentally by a 
local marine named Uzun Mehmet in November of 1829 when he was on leave in his hometown, a village called Kestaneci located in Ereğli, the largest town of Zonguldak. The unofficial version of this story, narrates that Uzun Mehmet is granted "5,000 kurush" [Ottoman penny] by the Ottoman Sultan who is very pleased upon the news, hence gives orders for putting Uzun Mehmet on a "600 kurush salary per month" for life (Seyda 7). Yet, soon rumours about Uzun Mehmet's discovery of a mysterious, burning stone and the Sultan's favours he was rewarded with, began to be whispered in the dark streets of Istanbul. Unfortunately, these envious whisperers pave the way for the tragic end of Uzun Mehmet on his last night in Istanbul, just before setting out back home. It is said that at the night of his assassination, he was staying in an inn called Leblebici Hant, and he was poisoned with help of a poisonous liquid secretly added into his coffee, and killed by some anonymous jealous haters from Zonguldak. Then, the assassins strangle him just to be sure of his death, and finally take the dead body of Uzun Mehmet out of the inn to be dumped in the middle of nowhere. From that day on, nobody sees Uzun Mehmet and unfortunately he has no chance to enjoy Sultan's favours. But, the people of Zonguldak still remembers him and his contribution to their city with his precious discovery. Today, many places in Zonguldak, including public parks, schools, and streets, are named after him.

As the so-called tragic end of Uzun Mehmet foreshadows, novelties were not welcomed and accepted easily by the conservative fractions of the Nineteenth century Ottomans. Firstly and mostly, they were approached with suspicion. Thus, dealing with coal in Turkey, starting from its first discovery, to its extraction, distribution and with many other steps, has been a difficult and painful process for Zonguldak, and for Turkey. Maybe that is why, Turkish novelist Mehmet Seyda opens his autobiographical novel with these lines: "Numberless hatches, black and bloody, were opened under the ground, and on top of them Zonguldak was founded (September 2, 1937)". ${ }^{1}$ Thus, "the numberless [black and bloody] hatches" that Mehmet Seyda highlights should be treated both literal and metaphorical senses: as the outcomes of both fighting against prejudices as well as resisting the envious/hateful gazes and the physical conditions. Similarly, emphasising the physically and psychologically painful process of coal mining, another literary figure, one of the most well-known Turkish poets, Orhan Veli Kanık describes the condition of the miners of Zonguldak in his 1946 poem:

On a sunny day

We'll see the Blacksea

1 Please note that all the translations from Turkish to English used in this article, including the novels, poems, and the secondary sources in Turkish belong to the Author unless another translator is cited. 
From Balkaya to Kapuz ${ }^{2}$

as blue,

We know this city like the palms of our hands

With the flowery gardens of EKI, ${ }^{3}$

With its wagons carrying coal to the port; With its pale-faced people who flock into the streets in the hours at the end of the work day,

The creeks of Zonguldak flow black,

Not as black as a shame,

But as black as coal,

'Cos that's how one earns his bread after all?

In the following years and centuries, this painful process pays off, and the coal mines of Zonguldak play a vital role in the industrialisation process of the Ottoman Empire, and later on of Turkey. Today, the great amount of the known anthracite reserves, high quality hard coal reserves, of Turkey is located mostly in the Zonguldak basin in the Black Sea Region of Turkey. The national reserves both of the lignite and anthracite coals are held by the General Directorate of the Turkish Hard Coal Enterprises (TTK). According to the data for 2015, the total reserve of only the anthracite, also known as hard coal, reserve is 1 billion 309 million tons. Total coal production in Turkey increasingly reached to 77 million tons in 2014, and the responsibility of this production process is shared by private sector and predominantly by public sector. Turkey's hard coal production, in particular, is carried out by TTK in Zonguldak. TTK gave only a part of production to private sector (Demirkiran 2016, 36-8).

So, coal holds a vital position for the industrial development of Zonguldak and its evolving from a small coastal town, as it was before coal mining activities started, to a busy mining city afterwards. That is why, there can be found many references to coal in Turkish literature. In this respect, Turkish novelist Mehmet Seyda's Yanartas [trans. The Burning Stone], an autobiographical narrative describing these years, is one of the most important accounts about coal in Turkish literature. In The Burning Stone, changing lives of the people of Zonguldak, the formation of a working class in the area along with the discovery coal, and the reshaping of the city with its natural environment are narrated from the eye of a fictional character named Osman, representing Mehmet Seyda himself, who arrives in Zonguldak in 1937, and starts working in State-run Zonguldak Coalfields Corporation in its first years of establishment. The novel covers the years between 1937 and 1943 in Zonguldak. Along with the establishment of coal mining and the miners' class, the cityscape rapidly changes too. The steep

2 The small port towns of Zonguldak.

3 Short for, Ereğli Coal Running Corp. 
mountains, thick woodland, and rocky beaches of Zonguldak begin to be invaded by industrial constructions, and reshaped in accordance with the rapidly increasing economic needs. Even the marketplace located in the downtown, which is one of the rare flat areas in the mountainous Zonguldak, is divided into two by a railway carrying coal from the mines at the outskirts first to coal washery (lavor) in the city centre and finally to the port on the coast to be loaded on the cargo ships to be transported elsewhere. In his essay “Mehmet Seyda'nın Yanartaş Romanında İşçi Sınıfı ve İşçi Kültürü," in which he analyses the treatment of the working class and the formation of the working class culture in Mehmet Seyda's The Burning Stone, sociologist Akın Bakioğlu, who is mostly known for his studies on the problems of the working class, especially of the coal miners in Turkey, sees this forced parallelism and the closely knit structure of mining areas and local people's residences as an handicap and the inevitable outcome of the difficult geography of Zonguldak (2014, 115-116). In other words, due to geo-morphological conditions of the city, the borders of industrialised areas, coal mines, and the area of local habitation intersect making coal literally a part of everyday life.

The background atmosphere of Yanartaş [The Burning Stone] is filled with the sounds of excavation, transportation of coal, as well as the miners on strike, with the images of pieces of coal dropped out of the railway carriages and the gipsy children collecting them to burn at home, and the dark water from the coal washery, or "lavour" to borrow the French terminology which is still in use in Zonguldak, leaking into the streets and the creek running through the city, the voices of mules carrying the coal to the steep and narrow places unreachable by the vehicles as well as the mines present a realistic description of a city and its inhabitants in parallel with the production of coal. Though inactive now, the towers of the old coal washery still decorates the Zonguldak cityscape, and the train carrying coal to the port trough the marketplace still has the priority of access over human and car trafficking even today. So, coal has been reshaping the cityscape of Zonguldak and the lives of its inhabitants since the Nineteenth century, and the history of Zonguldak can be read as the history of coal and coal miners in Turkey as well.

The changes entailing the increasing coal mining activities in Zonguldak and its surrounding can be categorised under three major headlines. The first category covers the demographic changes. When the coal was first discovered during the reign of Ottoman Sultan Abdulmajid II, the duty of running the mines in Ereğli basin was given to the Hazine-i Hassa, which a treasury reserved for the Sultan's private wealth and inner expenses, and also a supplementary treasury for the main treasury of the state, between 1848-1865. But in time, its financing was shadowed by rumours of corruption. Later on, between 1865-1909, this duty was transferred to the Ottoman Navy, and mining activities were conducted by the marines. Between 
1909 and 1920, the coal mines were state-run by the hand of the Administration of Trade, and after the 1920s, the running and administration of Zonguldak mines were passed to the Ministry of Finance. Yet, the major problem was to find qualified miners. In the absence of qualified Ottoman miners and engineering expertise, foreign miners from neighbouring countries such as Montenegro and Croatia, and engineers from France, Britain, and Russia were imported. In Yanartas [The Burning Stone], Mehmet Seyda notes that during these days, with the need for labour force increased in time, coal was being extracted through quite primitive methods:

Coal was carried out of the galleries in the underground collieries in pannier baskets loaded either on the shoulders of human miners or miner mules. The second option was to carry the coal out through the wooden wagons moving on the wooden rails tracks. Then the coal was unloaded in the threshing fields and reloaded to the mules to be transported to the loading docks. (Seyda 1970, 45)

Among the demographic changes following the increasing coal mining activities were the structural improvements for the increased number of miners. With the declaration of the republican regime, and the foundation of the Republic of Turkey, mines gained more importance. Laws regulating the work in the mines and the life around the mines passed rapidly. The first priority was establishing facilities for the non-local miners, such as residential houses, bath, heating, etc. Day by day, Zonguldak has become a popular city of employment taking mass migrations of miners from the neighbouring cities. In short time, this popularity led to the change of the cityscape and the architectural structure of Zonguldak.

The last, and maybe the inevitable, outcome following these developments was the use and abuse of local natural resources and the re-formation of the natural environment in accordance with the requirements of miners and mines. For example, the city was rapidly covered with a network of railways. This iron network was connecting the suburban countryside, in which the coal mines were located, to the urban ports where the extracted coal was loaded to cargo ships and transported to the other national ports. Moreover, the timber, which was needed inside the colliery to support the underground tunnels and to construct the wooden tracks carrying the coal out, was being provided by the thick forests covering the high mountains and steep hills surrounding Zonguldak. In addition, unfortunately the air of the city was rapidly contaminated by the coal dust that appear during the extracting process and by the sooth which remains hanging in the air after the burning process. In many literary and non-literary sources, the creeks nearby the coal mines are described as occasionally running blackish due to the coal washing process following the extraction process. In The Burning Stone, Mehmet Seyda describes 
the local children playing outside by floating their paper ships in the dark human-made creek created by the water flowing out of the lavour, coal washery towers located near the city centre.

So, along with these demographic, structural, and environmental changes triggered by the acceleration of coal mining activities in Zonguldak, the city metaphorically became an important national centre for the working class, hence initiated the formation of a working class culture and identity in Zonguldak. Employment of local labour force, immigrations from the neighbouring cities, construction of housing estates to accommodate the growing number of miners, and passing of legal regulations on the working conditions and hours in the mines are the first observable changes in this early period of coal mining in Zonguldak. Yet, for me, one of the most interesting part of the formation of a working class structure and culture in Zonguldak along with the discovery of rich coal reserves nearby is not only employment of human labour but also of the non-human labour; that is, the use of mules for the mining activities. Many mules, under local administration's protection, are recruited and recorded under the title of "miner mules", performing loading and unloading coal in and out of the underground mines, helping to rescue miners underground during possible explosions, etc., and this practice continued till 1980s. According to Bakioğlu, the use of mules in Zonguldak was also a direct result of the condition of mines in the 40s which offers very "little possibility for mechanization" $(2014,117)$ due to their geographical location. The steep, mountainous locations of the mining areas hosting the richest coal reserves were not easily accessible. Moreover, due to the length and narrowness of the tunnels inside the coal mines limiting any human movement inside and the difficulty of construction of any mechanical carriage system as well as the cost of such a mechanical construction under the economically challenging conditions in the country, miner mules were seen as the most practical and least costly alternative to mechanization in the mines.

Animal-powered carts, wagons, carriages, cabs, street-cars, and omnibuses filled the streets of the Nineteenth century (Hribal 2007, 104). So, in the Nineteenth century context, using mules in mining activities and inside the mines was not a rare practice, which was unique to Turkish coal mines. Carrying coal out of the mines through mules was a common practice in many European countries, like Britain and France for many years, and mules are continued to be used in the mines "in many countries such as the UK and the USA till the end of the 1990s" (Uzar Ozdemir 2017, 258). In her essay "Zonguldak'taki Madenci ve Çöpçü Katırlar", in which she explores the use of mules as miners and garbage collectors in Zonguldak, sociologist Figen Uzar Ozdemir states that some mules were brought to the mines when they are six months old and continue to work in the mines for 25-30 years till they are retired (259). Similar to Uzar Ozdemir emphasising the length of a regular miner mule's employment, 
mining engineer Nadir Avsaroğlu emphasises the long working hours of the miner mules and he strikingly informs that sometimes the mules would "stay under the ground for 24 hours" $(2017,126)$.

The improvements in the mines and especially the facilities outside the mines start with the Law no. 2/14547 which passed in 15 October 1940 with the transfer of the state authority to run Zonguldak mines to EKI (Ereğli Coalmining Corporation). This improvements also included the working hours for miners, age limits for employment, extra facilities for the miner families such as meeting their social, educational, medical, residential needs, and so on. In Yanartas (The Burning Stone), Mehmet Seyda states that with the new legal regulations executed by the government in the early 40s, and expected to be effective in the state-run mines in Zonguldak, not only the miners' working space and its surrounding but also of the miner mules' were structurally re-organised. First, all the miner mules were taken under official record and given a nail number. Moreover, with a similar improvement in the work and social standards of the human miners, their nonhuman collaborators, the miner mules's life standards also changed. For example, special-designed stables for the miner mules were built underground. Above the ground, for them, special animal keepers, stablemen and vets were assigned to preserve their well-being. However, life in the coal mines was still extremely hard for the miner mules.

In his newspaper article published in the most prestigious local newspaper of Zonguldak; Pusula, in 12 May 2017, the Turkish journalist Yüksel Ylldırım underlines the contributions of the miner mules diligently:

These miner mule had served for many years in the coal mines run by public and private sector under the General Directory of TTK. Since the early 1980s, 40 recorded mules can be found having served in the coal mines located in Armutçuk, Amasra, Üzülmez, Kozlu and Karadon as locomotives carrying coal-loaded wagons out, and the various necessary materials in, helping the manoeuvring of 4-6 ton-weight wagons. They also used in the rescue missions for the miners who are stuck underground after firedamp gas explosions as well as the cleaning afterwards. Mules were able to enter the narrow places where miners could not reach. Some of them are even injured during these missions. Eventually, [due to the harsh working conditions] most of these mules died either of bowel infection or muscle weakening.

Occasionally these miner mules attracted the attention of the national and local newspapers. For example, Avşaroğlu mentions about a news headline published in Hurriyet, a well-known and largely circulated national newspaper, headlined as "Miner Mules Support their Owners Financially" and dated with 22 September $(2010,129)$. The news is about a miner mule working in a private coal mine located in Karadon area in Zonguldak 
as carrying coal outside the mines. The owner of the miner mule is also a miner named İlyas Alaca. Alaca describes his mule as his "best friend and colleague" $(2010,129)$, and he continues: "We descend to the underground, enter and exit the mine together. My mule carries out the coals loaded into a wagon inside the mine. Without my mule I could not perform such a heavy job by myself" $(2010,129)$. As it is seen in the abovementioned statements of İlyas Alaca, for the owner his mule was more than an asset, an object to be possessed, but like a family member. Jason Hribal cites some anecdotes from Ireland, England and Canada, underlining the emotional attachment that the mule owner/keeper and the developed for their mules after their collaboration:

Mike Scorback, a teamster from Thunder Bay, Canada, [narrates that] "there were some horses in camp with raw necks. Guys didn't clean them. I used my own water to heal them with urine and I cured them in two weeks and stole oats from the barn boss to give the horses more blood." [Because] "they were my chums, those horses." The English miners at Denaby Coal Mine "used to send beer down t'pit for 'em, for the ponies, as sort of medicine." (Hridal 2007, 103)

Similarly, it is known that the keepers of the mules employed by Zonguldak municipality were naming the mules under their care as "Gaye" or "Kadife", which are the names with anthropomorphic connotations (Uzar Özdemir 2017, 262). This clearly shows the emotional attachment of the miner to his nonhuman collaborator.

On the other hand, the news headline of Hurriyet published in 24 January 2001, was sadly declaring the death of the last miner mule in Armutçuk mines (Karadeniz Ereğli, Zonguldak). According to the details in the news, this last miner mule had been working as locomotive, literally, carrying coal-loaded wagons out of the underground mine, and died of bowel infection and muscle deformation after its 27 years of service in the Zonguldak coal mines. The same news took place in other news portals, too, like NTVMSNBC, with the statements of the authorities of TTK declaring the material value of this mule, which has been considered as the official property of the institution, as " 110 million 923 thousand and 92 Turkish Liras" (2001). This mule was like the iconic symbol or mascot of the institution and its death is reported to cause deep sorrow among the miners. The mule was working under the ground for such a long time that, when it was taken above the ground, its eyes becoming extremely sensitive to sunlight were almost blind. This was the last time, a mule was settled underground stables under hundreds of metres.

Focusing on the pain observable in the eyes of the miner mule called "Alagöz" (Hazel Eyed), another well-known Turkish author Rifat Ilgaz, mentions the miner mules and their daily routine in one of his poems. 
The name of the miner mule described in Ilgaz's poem is "Alagöz". Here is the poem:

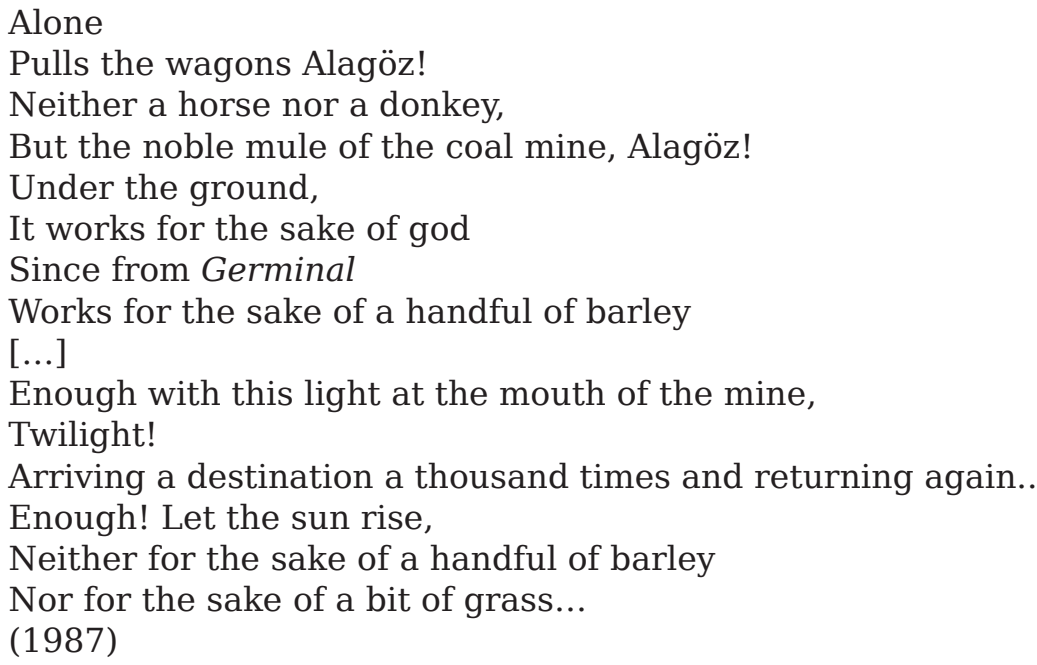

After 1988, the employment of mules in the mines was prohibited legally due to the increasing number of casualties in the employed miner mules' population as well as the decrease in the need to them thanks to mechanization. But today, mules are still employed by the local administration in Zonguldak as garbage collectors. Yet, considering the physical handicaps posed by the geographical structure of Zonguldak and its surrounding areas, as well as the lack of mechanization in the early coal mines, in the absence miner mules, mining activities in Zonguldak's coal mines probably would not develop that soon. Moreover, considering the parallel improvements in the legal rights and the working conditions of both human and nonhuman labour forces, the working class identity built among the miners of Zonguldak owes a lot to the collaborative presence of their miner mules. In this respect, it can be argued that miner mules both accelerated the industrial production of coal in Zonguldak and contributed to the reclaiming the miners' rights. So, in Zonguldak, nonhuman labour through their physical and emotional attachments with their human collaborators has remained an indispensable part of human labour for many years. Yet, in time, especially with the decreasing need to miner mules as a result of mechanization, and the use of technological advances in mining, human labour began to be prioritised over nonhuman labour. In this context, miner mules were just used, mostly abused, and treated merely as means of production. Thus, the exploitation of nonhuman labour by humans, as illustrated in the case of miner mules in Zonguldak, can also be read as just another example of anthropocentricism, putting human well-being over 
the well-being of any nonhuman element of nature including the natural resources, plants and animals. In this respect, this anthropocentric tendency highlights the persistence of the ongoing reckless exploitation of natural resources for the sake of human needs.

In a nutshell, as Bakioğlu argues with "the autobiographical elements" in Mehmet Seyda's novel Yanartas, its "nonfictional structure" $(2014,121)$ can be treated as a reliable documentary and "a realistic representation of the period it was produced" $(2014,121)$. In this respect, it gives the reader a reliable perspective on the working class-environment entanglements based on coal mining in Zonguldak as well as the human-nonhuman collaboration for the extraction of coal. The illustrative examples from the chosen literary works unfortunately prove the unequal distribution of power among the human and nonhuman elements. Not only the natural resources but also the nonhuman animals inhabiting this particular environment, Zonguldak, suffered under heavy exploitations of humans. The case of Zonguldak coal mines is not an exception, but just another example of a global situation in which human needs are prioritised over environmental sustainability.

\section{Bibliography}

\section{Primary Source}

Ilgaz, Rıfat (1987). Ocak Katırı-Alagöz: Poems. İstanbul: Çınar Yayınları. Kanık, Orhan Veli. "Yüz Karası Değil, Kömür Karası" [online]. URL http:// wWw. antoloji.com (2017-09-11).

Seyda, Mehmet (1970). Yanartas. Vols. I-II. Istanbul: Ararat Yayınevi.

\section{Secondary Sources}

Avşaroğlu, Nadir (2010). "Madenlerde Çalıştırılan Son Katır”. Mühendislik Mimarlık Öyküleri, IV.

Ankara. Türk Mühendis ve Mimarlar Odaları Birliği, 119-28.

Bakioğlu, Akın (2014). “Mehmet Seyda’nın Yanartaş Romanında İşçi Sınıfı ve İşçi Kültürü". Emekçileri Okumak. Mustafa Kemal Coşkun (ed.). İstanbul: Evrensel Basın Yayın. 103-21.

Chakrabarty, Dipesh (2009). "The Climate of History: Four Theses”. Critical Inquiry, 35(2), 197-222.

Crutzen, Paul J.; Stoermer, Eugene F. (2000). "The Anthropocene”. IGBP Newsletter, 41, 17.

Crutzen, Paul J. (2002). “Geology of Mankind”. Nature, 415(3), 23. 
Demirkıran, Halim (2016). "Coal Mining in Turkey and its Role in Energy Supply". Mining Turkey, Spring, 36-46.

Hribal, Jason C. (2007). "Animals, Agency, and Class: Writing the History of Animals from Below". Human Ecology Review, 14(1), 101-12.

Malm, Andreas (2016). The Fossil Capital: The Rise of Steam Power and the Roots of Global Warming. New York. Verso.

McNeill, J.R.; Engelke, Peter (2014). The Great Acceleration: An Environmental History of the Anthropocene since 1945. Cambridge (MA): The Belknap Press of Harvard University Press.

“Media note: Anthropocene Working Group (AWG)" (2016). Leiceste: University of Leicester Press Releases.

“TTK'da Görevli Son Katır da Öldü” (2017). Online News Portal.

Uzar Özdemir, Figen (2017). "Zonguldak'taki Madenci ve Çöpçü Katırlar". "Yüz Karası Değil, Kömür Karası" Zonguldak. Ed. by Atilla Barutçu, Figen Uzar Özdemir. İstanbul: İletişim, 257-68.

Yıldırım, Yüksel (2017). "Kadrolu Katırlar". Pusula. 


\author{
Through the Working Class \\ Ecology and Society Investigated Through the Lens of Labour \\ edited by Silvio Cristiano
}

\title{
Beyond the Dark, Satanic Mills An Ecocritical Reading of $A$ Kestrel for a Knave
}

\author{
Joanna Dobson \\ (Sheffield Hallam University, Sheffield, UK)
}

\begin{abstract}
Barry Hines' 1968 novel A Kestrel for a Knave is justly celebrated for its depiction of working-class life in an English mining village. However, false assumptions about the role of 'nature' in the working-class experience have led critics to overlook the significance of the bird at the centre of the novel and the descriptions of the surrounding environment. A reading that foregrounds these aspects offers new insights, revealing a prescient anxiety about the way capitalism weakens relationships between human and nonhuman. The book is shown to be ahead of its time in its understanding that human flourishing depends on meaningful connection with the more-than-human world.
\end{abstract}

Keywords Animal studies. Barry Hines. Birds. Ecocriticism. Northern England. Working-class writing.

Barry Hines' much-loved 1968 novel A Kestrel for a Knave tells the story of Billy Casper, a young teenager growing up in a coal mining village in South Yorkshire, and his relationship with a kestrel called Kes. In an afterword to the Penguin Modern Classics edition of the book, Hines writes that one of the questions he is most frequently asked is how he knows so much about the countryside, since he too grew up in a mining community in the north of England. He goes on:

It's an ignorant question but understandable, because many people still have a vision of the north filled with 'dark satanic mills', mines and factories, and not a blade of grass in sight. When I try to explain that the mining village in which I was born and brought up - just a few miles from Barnsley - was surrounded by woods and fields, I can tell they don't believe me. (Hines 2000, 199) ${ }^{1}$

Such a misconception about the place of the countryside in England's industrial north is deep seated and spreads well beyond the classrooms and literature festivals where Hines used to be invited to talk about his books.

1 Barnsley is a large town (pop. 91,000) in the north of England, known for its industrial heritage, especially coal mining.

Culture del lavoro 8 ISSN [online] 2610-9379| ISSN [print] 2610-8852

DOI 10.30687/978-88-6969-296-3/008 | Submitted: 2018-07-20 | Accepted: 2018-09-16

ISBN [ebook] 978-88-6969-296-3 | ISBN [print] 978-88-6969-297-0

(c) 2018 | (1) Creative Commons Attribution 4.0 International Public License 
For example, Head, discussing the relationship between post-war British novels and depictions of rurality, suggests that one of the reasons for the decline in fictional representations of nature was the rise of the workingclass novel and "the post-war identification of working-class experience with the industrial north of England" (2002, 190). Implicit in this claim is an assumption that 'nature' is irrelevant to the northern working-class experience. Such preconceptions may explain why the little criticism that there is of A Kestrel for a Knave tends to pass over the extended descriptions of the countryside surrounding Billy's town. In addition, despite the fact that the central theme of the book is the relationship between a bird and a boy, critics have failed to engage fully with the importance of the more-than-human world to the book as a whole. Generically, the book has tended to be identified with the so-called 'working-class novel' (Hawthorn 1984, Haywood 1997, Day 2001, Kirk 2003) and as a result, critics may have seen only what they expected.

A reading of the novel that foregrounds the representation of the morethan-human world provides important new insights into both Billy's character and the book's prescient understanding of the tendency of industrial capitalism to separate human and other-than-human to the detriment of both. The exception to the type of criticism referred to above is a recent essay in which del Valle Alcalá interprets A Kestrel for a Knave through the philosophy of Deleuze and Guattari and suggests that Billy's relationship with Kes - his 'becoming-kestrel', to use the Deleuzian term - opens "a hitherto unexplored trajectory of being, composing a new cartography of subjectivity that is no longer determined by external factors or by the overarching dictates of an abstract capitalist machine" $(2016,393)$. As del Valle Alcalá suggests, to read Billy only in terms of his economic situation is to enmesh him even more tightly in the capitalist system that is failing him, whereas to read him in terms of the dynamics of his relationship with the bird opens the possibility of a much fuller understanding of his potential.

In my reading, I will focus on how the more-than-human world plays a crucial role as a site of resistance and identity formation for Billy, as well as being a place in which historic ideas about class and land ownership are inscribed. I will pay close attention not just to Billy's relationship with the kestrel, as del Valle Alcalá does, but also to the varied natural and built environments in which the story takes place. In so doing, I will demonstrate that the book is permeated with a profound anxiety about the future of humanity that is related not only to the dehumanising effects of industrial modernity but also, in a way that is ahead of its time, to the danger of people's weakening connections with the more-than-human world in the decades following the Second World War.

One consequence of reading $A$ Kestrel for a Knave solely as a 'workingclass novel' is that the focus is likely to be on the extent to which Billy's alienation arises from the fact that the only future available to him is that 
of becoming a waged labourer like his miner brother, Jud. It is not that this reading is invalid, but rather that it is incomplete. Despite the political edge to the book, Billy is much more than "an endorsement of essentialist socialist constructions of the working class" (del Valle Alcalá 2016, 374). While I accept that the lottery of his birth into a working-class family in a mining town is part of the reason for Billy's fragmented sense of self, he can only be fully understood if it is recognised that his primary wound arises from the loss of his father and the subsequent disintegration of his home environment. This aspect of Billy's identity is something that Day misses when he says that "Billy's hawk symbolises his spirit" $(2001,187)$ and quotes the passage where Billy tells Mr Farthing that Kes is "not bothered about anybody, not even about me" (cited in Day 2001, 187; see Hines 2000, 146). In fact, Billy is very bothered indeed about the other people in his family at least: when he writes a 'tall story' 2 in his English class, he conjures a happy home and his father returning (Hines 2000, 89); when he is at his lowest point after the death of Kes, he heads almost unconsciously for the disused cinema where he had his last experience of happiness and intimacy with his father (194).

Day's misreading is the result of reducing Kes to a mere cipher in the text, assuming that her sole function is to tell the reader more about Billy, rather than paying attention to her avian quiddity. In fact Kes exists in the text very much as a bird in her own right: there is none of the "moralising subjection" or "anthropomorphic taming" that Derrida criticises when he writes about animals in fables $(2002,405)$. A reading that recognises the distinctness of Kes's identity also allows for a fuller understanding of Billy, whose identity is shaped by two profound experiences of disconnection. One is the savage rupture of any sense of belonging to a family when his beloved father walks out after discovering Billy's mother's adultery (Hines $2000,195)$. The other is the alienation he experiences, along with his peers, as a working-class teenager growing up under industrial capitalism. Acting against both these disconnects is his relationship with Kes and with the wider natural world that surrounds his mining town.

Billy first encounters kestrels on an early morning walk, when he is captivated by the hovering and stooping of a pair that has a nest in the wall of an ancient monastery (Hines 2000, 35). Elsewhere I have argued that birds are "good to think with" because they embody both similarity to, and difference from, humans (Dobson 2017, 16). This encounter highlights the obvious contrast between the birds' freedom and Billy's lack of life choices, and between their ability to soar high in the sky and the fact that Billy's future will almost certainly be played out below the ground in a dark coal mine. As the book progresses, it probes more deeply and

2 A story that seems unlikely or unbelievable. 
subtly into both the contrasting and the contiguous aspects of the situation of bird and boy.

One reason why it is able to do this so effectively is that Kes becomes a trained falcon and thus takes up a richly creative space on the boundaries between wild and domesticated. In fact Kes, like other trained falcons, can be said to transcend the wild-domesticated binary by freely co-operating with Billy while still retaining the ability to fly away. Billy too shows characteristics of what might be called 'wildness'. These emerge partly through his refusal to compromise at school, such as when he ultimately triumphs over Mr Sugden's bullying in the showers after PE, using the exceptional, monkey-like climbing skills that he demonstrates throughout the book (Hines 2000, 133). More significantly for my reading of the book, Billy's wildness is also demonstrated through his sensitivity to the more-thanhuman world. In the following extract, he is on the walk on which he will eventually discover the nesting kestrels:

A cushion of mist lay over the fields. Dew drenched the grass, and the occasional sparkling of individual drops made Billy glance down as he passed. One tuft was a silver fire. He knelt down to trace the source of light. The drop had almost forced the blade of grass to the earth, and it lay in the curve of the blade like the tiny egg of a mythical bird. Billy moved his head from side to side to make it sparkle, and when it caught the sun it exploded, throwing out silver needles and crystal splinters. He lowered his head and slowly, very carefully, touched it with the tip of his tongue. The drop quivered like mercury, but held. He bent, and touched it again. It disintegrated and streamed down the channel of the blade to the earth. (Hines 2000, 30)

This careful, detailed description, together with the references to precious metals and mythical creatures, demonstrates how close Billy is to participation in a world of beauty and creativity that lies almost literally on the doorstep of the squalor and violence that characterise his home and school. Touching the raindrop with his tongue, he evokes a very young child exploring the environment with a kind of playfulness that is also a way of learning. However, in Billy's education there is no room for play. School is a joyless place where he is being prepared for a particular kind of work, one that stands in binary opposition to the idea of play and assigns him a dehumanising role in the machine of industrial capitalism. Images like this of physical contact between humans and the more-than-human world play a powerful role in A Kestrel for a Knave.

Billy's affinity with the more-than-human world is depicted as something unusual. Although he had been expecting some other boys to come out 
nesting ${ }^{3}$ with him, they have all failed to turn up, and Jud draws attention to his difference by calling him "Billy Casper! Wild man of the woods!". He goes on: "I ought to have thi' in a cage. I'd make a bloody fortune" (Hines 2000 , 45). ${ }^{4}$ This hints at a theme that goes on to become more dominant at the end of the book, which is that the further the teenagers of Billy's town are acculturated into the narrow expectations of school and work, the weaker their connection with the more-than-human world. Jud, who is already employed in the mine, is at the far end of this scale, and as a result can only see Billy's wildness as something to be captured and commodified.

Thus Billy's situation is simultaneously akin to Kes's, and radically different. He is like Kes because he inhabits a marginal space between wild and domesticated, but unlike her because, crucially, their training has different goals. The purpose of Kes's training is to allow her to retain her wildness and her agency, to make her own decisions about whether to obey her trainer or not. As Billy explains to Mr Farthing:

(I)t makes me mad when I take her out and I'll hear somebody say, 'Look there's Billy Casper there wi' his pet hawk.' I could shout at 'em; it's not a pet, Sir, hawks are not pets. Or when folks stop me and say, 'Is it tame?' Is it heck tame, it's trained that's all (Hines 2000, 146).

In complete contrast, the goal of Billy's education is to strip him of his individuality and agency in order that he can be placed in the machine of industrial capitalism. His 'careers' interview offers a stark choice between office and manual work. In a telling detail, the cover of the pamphlet entitled Leaving School situates the school leaver inside, while the window onto the world of tree, bird and sky - the world in which Billy is most obviously himself - is out of reach behind the boss's desk (Hines 2000, 172). This contrast between Billy and Kes illustrates the Marxian concept of alienation, in particular the idea that workers within the capitalist mode of production experience estrangement from their Gattungswesen, or 'species-being' (Mészáros 1970, 14). While Kes, in Mr Farthing's words, "just seems proud to be itself" (Hines 2000, 147), Billy is being progressively cut off from opportunities to fulfil his potential as a human being, which in his case would almost certainly include meaningful work outside.

Kes offers Billy a chance to resist the expectations placed on him by school: in training her, he becomes both teacher and student and this as-

3 Collecting eggs from the nests of wild birds, a practice that became illegal in Britain in 1954.

4 Barry Hines' decision to render the speech patterns of working-class Yorkshire people as accurately as possible was ground-breaking for the period. The glossary at the end of this paper explains unfamiliar spellings and words in standard English. 
pect of the boy-bird relationship is an opportunity for the book to figure a different type of education to the one Billy experiences in the bottom stream at school, where he has "a job to read and write" (Hines 2000, 170). Once he decides to train Kes, he is driven to get hold of a book on falconry by any means possible. The lesson on fact and fiction, in which he tells the class and his teacher, Mr Farthing, about how he is training Kes, shows that he has mastered a range of technical words from falconry. For a few minutes, the teacher-pupil relationship is radically subverted as Billy takes control of the signifying system, telling Mr Farthing what the words mean and how to spell them (Hines 2000, 79). Such a role reversal, however temporary, shines a powerful light on the extent to which Billy is denied the chance to achieve his potential as a result of being trapped in a system that is determined to dictate the narrative of his life.

As he captures the class's attention with his fluent descriptions, Billy demonstrates that his connection with the bird is enabling him to fulfil a key feature of his Gattungswesen, namely the skilled use of language. The use of complex language has historically been cited as something that sets humans above other kinds of animal. However, this is not the message of A Kestrel for a Knave. Billy's powers of expression are seen as essential to his individuality, but the book is also aware that industrial modernity is working to separate humans from their own animality and that this too constitutes part of the estrangement from their full humanity. One of the ways that Billy is shown as more in touch with his animal self than many is through images of physical contact. When his hands are bleeding after handling the kestrel chicks, it is "as though he had been nesting in a hawthorn hedge", the image setting up a direct connection between Billy and the birds (Hines 2000, 54). The significance of physical connection with the more-than-human world can also be seen in the English lesson scene. When Farthing asks Anderson to tell the class a "really interesting fact" about himself (Hines 2000, 73), Anderson responds with a story about putting his bare feet into a pair of wellingtons full of live tadpoles (75). To Twenty-first century sensibilities, this sounds alarming, but as Kerridge relates in his memoir of growing up in the 60s, it was not unusual for children, especially boys, to develop a fascination with amphibians:

Children were routinely given frogspawn or tadpoles, and older boys often kept newts or Grass Snakes in tanks for a while [...] These were still the days when boys of eight climbed trees and dammed streams and lit campfires in the woods, dreaming that they were Robin Hood [...] The collecting of wild birds' eggs had only recently been made illegal $(2014,11)$.

Anderson's story is at heart another story of play, recalling Billy's tasting of the raindrop. The tadpoles on the edge of this small mining town are 
abundant in a way that is hard to imagine now, even in the countryside. "Edges of t'pond are all black with 'em," says Anderson (Hines 2000, 73) and after what seems like hours of ladling, the wellies are "jam packed with taddies" (74). The thought of putting the wellies on is first frightening and then disgusting - "I could feel 'em all squashing about between my toes" (74), but once he gets used to them, Anderson is emboldened:

it was all right after a bit; it sent your legs all excited and tingling like. When I'd got 'em both on I started to walk up to this kid waving my arms and making spook noises; and as I walked they all came squelching over t'tops again and ran down t'sides. This kid looked frightened to death, he kept looking down at my wellies so I tried to run at him and they all spurted up my legs.

It was a funny feeling though when he'd gone; all quiet with nobody there, and up to t'knees in tadpoles' (Hines 2000, 75).

The episode has led Anderson through a whole gamut of emotions from disgust to excitement; then it has enabled him to play-act with the other children; finally, left alone, he experiences the eeriness that can come from encountering the more-than-human world. Anderson in this story is alive to all his senses and processing new experiences in a way that seldom happens in the classroom where, as Billy says, the teachers "talk to us like muck [...] callin' us idiots, an' numbskulls and cretins" (Hines 2000, 101). As Hines makes clear in his afterword, one of the main themes of $A$ Kestrel for a Knave is the injustice of the education system. "The elevenplus system was ruinously divisive at all levels", he writes $(2000,201) .^{5}$ In Anderson's story, and in Billy's experience of teaching himself to train Kes, there are hints of a much more humanising way of learning that engages all the senses and does not divide children from each other.

Anderson's story paves the way for Billy to tell the class about Kes and he also uses strongly physical terms to describe achieving his ultimate ambition of flying Kes free and having her return to him:

She came like lightnin', head dead still, an' her wings never made a sound, then wham! Straight up on to t'glove, claws out grabbin' for t'meat," simultaneously demonstrating the last yard of her flight with

5 The eleven-plus examination used to be compulsory for all British children as they finished primary school at the age of ten or eleven. Children who passed were offered places at a grammar school, where they would receive an academic education that prepared them for university and/or white-collar jobs, while those who did not would proceed to a technical education and thence to manual or low-level office work. From early on it was claimed that the test had a class bias, with middle-class children far more likely to end up at grammar school than their working-class peers. 
his right hand, gliding it towards, then slapping it down on his raised left fist (Hines 2000, 85).

The moment of physical contact between bird and boy represents a rare moment of joy and achievement in Billy's life. "It wa' a smashin' feeling," he says. "You can't believe that you'll be able to do it. Not when you first get one, or when you see 'em wild" (Hines 2000, 85).

In complete contrast, Jud's experience of physical contact with Kes leads him to kill her. As if by way of excuse, he says:

It wa' its own stupid fault! I wa' only going to let it go, but it wouldn't get out o' t'hut. An' every time I tried to shift it, it kept lashing out at my hands wi' its claws. Look at 'em, they're scratched to ribbons! (Hines 2000, 183).

When Billy's hands were scratched by kestrels, he was compared to a bird nesting, but the lacerations on Jud's hands render him brutal: first he kills the kestrel and then he violently attacks Billy. This is another example of Jud, who is already working in the mine, being portrayed as more thoroughly alienated than the other young men in the book, and one of the signs of it is a loss of connection with his own animality, which could have led him into an intelligent relationship with the bird.

Kes's status as a trained falcon also enables the book to draw attention to the long history of class prejudice in England, one that extends back well before the Industrial Revolution. The title of the book is taken from the Fifteenth century Boke of St Alban's, quoted in the epigraph:

An Eagle for an Emperor, a Gyrfalcon for a King, a Peregrine for a Prince, a Saker for a Knight, a Merlin for a Lady; a Goshawk for a Yeoman, a Sparrowhawk for a Priest, a Musket for a Holy water Clerk, a kestrel for a Knave (Hines 2000, 7).

People and birds are here arranged in strict order of status, with the knave, or Billy, at the bottom. Barry Hines' brother, Richard, whose experiences of training kestrels were part of the inspiration for A Kestrel for a Knave, recalls in his memoir his amazement at discovering that medieval falconers flew peregrines on the moors near his Barnsley home. "Yet had I lived in those times, I wouldn't have been allowed to fly a peregrine on the moor," he writes (Hines 2016,62). His social class would have allowed him only to have a kestrel, a bird "derided by falconers in the Middle Ages" (63).

That notwithstanding, in Marxian terms, this feudal era was less oppressive than the age of capitalism, since despite the strict hierarchy, a culture of connection prevailed. Marx and Engels express it rather unrealistically: 
The bourgeoisie, wherever it has got the upper hand, has put an end to all feudal, patriarchal, idyllic relations. It has pitilessly torn asunder the natural feudal ties that bound man to his 'natural superiors', and has left remaining no other nexus between man and man than naked self interest, callous 'cash payment' (2010, loc. 135).

The medieval labourer working long, backbreaking hours for the lord of the manor might have been hard pressed to find much that was idyllic in his life. Nevertheless it is at least true that in feudal times workers were more closely connected to the more-than-human world than they were under industrial capitalism. This earlier period is evoked in A Kestrel for a Knave when Billy discovers that the birds are nesting in the wall of a ruined monastery, a relic of a pre-industrial age when people of his class would have had more opportunity to work outside. The current economic system works to exclude him from the land: as he pursues the kestrels, he is confronted by the farmer who tells him to "bugger off" because "this is private property" (Hines 2000, 37). This passage is further evidence of the book's concern that under industrial capitalism, working-class exclusion extends to a separation from the more-than-human world. "You ought to have seen it, mister, it was smashin'", enthuses Billy, only to be laughed at because the farmer and his little girl can see the kestrel every day on their private land. "I wish I could see it every day", replies Billy poignantly (37). Discussing the representation of the rural in post-war fiction, Head refers to the writing of Thomas Hardy and D.H. Lawrence, saying that they confront the reader with "superficially 'natural' images in which questions of social history are inscribed in the landscape" $(2002,189)$. The implication is that such writing ceased after the 50s, but in this and other episodes in A Kestrel for a Knave, Hines is seen to be doing the same thing.

The encoding of class structures within Billy's surroundings is a recurrent theme, notably in the description of his newspaper delivery round. This early episode locates Billy as a child of the housing estate, ${ }^{6}$ suspect in comparison to the "grand lads" from areas such as Firs Hill (Hines 2000, 14). Natural features within the built environment serve to illustrate social stratification: on Firs Hill there are wide verges, trees and rhododendrons; the rich children whose father owns a Bentley live in a detached house set back from the lane. However, despite his estate origins, Billy is at home all over the town and knows how to negotiate the varied terrain: he is sly and successful in his thefts of chocolate and orange juice, and moves around as swiftly and sure-footedly as a fox might, climbing fences, squeezing through hedges and using short cuts to help him complete the job before school starts.

6 A large complex of public homes built by local municipalities and rented to people on low incomes. 
After the death of Kes, Billy's perception and negotiation of his environment undergo a distressing change, a sign not only of his deteriorating mental state but also of his decreasing ability to resist the pressure to order his life in the way dictated by the prevailing power structures. When Kes goes missing, he embarks on a desperate race through the darkening woods that contrasts starkly with his earlier moonlit excursion to fetch her from the nest. His deft negotiation of different terrains is replaced with stumbles and trips, and when he emerges into the farmland, the wall of the monastery, that relic of an earlier, pre-capitalist age of connection, and a communal landmark for centuries, has been destroyed (Hines 2000, 179).

The final stage of the book describes Billy's ghastly flight through the estate, dead hawk clutched in sweaty palm (Hines 2000,188). Where the paper round highlighted variety in Billy's landscape, the emphasis now is on the sameness of his surroundings:

On both sides of this road, and the next, and along all the Roads, Streets, Avenues, Lanes and Crescents of the estate, the houses were of the same design: semi-detached, one block, four front windows to a block, and a central chimney stack. This pattern was occasionally broken by groups of pensioners' bungalows, tucked into Closes, but built of the same red brick as all the other dwellings. (Hines 2000, 188)

The uniformity of the homes mirrors that of products issuing from the conveyor belts of industrial capitalism. The layout of the estate is an example of what Tally calls "conceptual gridding", a state attempt to segment the rank and file and "assign stable places" $(2013,136)$. Whereas Billy's paper round showed him negotiating space in a way that defied these kind of prescriptive boundaries, now he is seen to be caught inside them. And whereas his paper round was full of references to the more-than-human world, the emphasis now is on its absence. The gardens are mostly "uncultivated squares of stamped soil" (188), though a few have lawns with stone birds, gnomes and artificial toadstools "all illuminated in unnatural shades" (189). Cars are parked on seeded verges and trees have been reduced to "saplings surrounded by guards of spiked railings" that are used as litter bins (190).

Finally, Billy arrives at the disused cinema, the site of his last happy memory of his father. Here he enters a quasi-hallucinogenic state in which he imagines himself on the big screen, flying Kes. His mental disintegration is mirrored in the staccato quality of his language: "Billy as hero. Billy on the screen. Big Billy, Kes on his arm" (Hines 2000, 196). He tries to imagine Kes attacking Jud, and the repeated refrain "No contact! No contact!" is not just about the failure of this image. In the context of the rest of the book, it is A Kestrel for a Knave's final verdict on Billy's fate. Severed from his family, severed from meaningful work and increasingly severed 
from the more-than-human world, Billy's disconnection is complete. This separation, which can only be seen fully in a reading that pays careful attention to the representation of the more-than-human world, is depicted as a loss of humanity and anticipates present-day ecological thinking in its understanding that human flourishing is dependent on a recognition of our interconnectedness with the wider natural world.

Glossary of Dialect and Slang Words Used in Quotations from A Kestrel for a Knave

$\begin{array}{ll}\text { an' } & \text { and } \\ \text { 'em } & \text { them } \\ \text { callin' } & \text { calling } \\ \text { grabbin' } & \text { grabbing } \\ \text { heck } & \text { hell } \\ \text { lightnin' } & \text { lightning } \\ \text { numbskulla } & \text { stupid person } \\ o^{\prime} & \text { of } \\ \text { smashin'smashing } & \text { wonderful } \\ \text { spook } & \text { ghost } \\ \text { taddies } & \text { tadpoles } \\ t^{\prime} & \text { the } \\ \text { thi' } & \text { you } \\ w a^{\prime} & \text { was } \\ w i^{\prime} & \text { with }\end{array}$

\section{Bibliography}

Day, Gary (2001). Class. London: Routledge.

del Valle Alcalá, Roberto (2016). "Class, Embodiment, and Becoming in British Working-class Fiction. Rereading Barry Hines and Ron Berry with Deleuze and Guattari". College Literature, 43(2), 375-96.

Derrida, Jacques (2002). "The Animal That Therefore I Am (More to Follow)". Critical Enquiry, 28(2), 369-418.

Dobson, Joanna (2017). 'Nesting in English Fields'. Bird Narratives and the Re-Imagining of Post-War Britain [Unpublished MA Thesis]. Sheffield: Sheffield Hallam University. URL http://shura.shu.ac.uk/18745/. Hawthorn, Jeremy (ed.) (1984). The British Working-Class Novel in the Twentieth Century. London: Edward Arnold. 
Haywood, Ian (1997). Working Class Fiction from Chartism to "Trainspotting". Plymouth: Northcote House.

Head, Dominic (2002). The Cambridge Introduction to Modern British Fiction, 1950-2000. Cambridge: Cambridge University Press.

Hines, Barry (2000). A Kestrel for a Knave. London: Penguin.

Hines, Richard (2016). No Way but Gentlenesse. A Memoir of how Kes, My Kestrel, Changed my Life. London: Bloomsbury.

Kerridge, Richard (2014). Cold Blood. Adventures with Reptiles and Amphibians. London: Chatto and Windus.

Kirk, John (2003). Twentieth-Century Writing and the British Working Class. Cardiff: University of Wales Press.

Marx, Karl; Engels, Frederick (2010). Manifesto of the Communist Party. Kindle edition. Project Gutenberg.

Mészáros, István (1970). Marx's Theory of Alienation. London: The Merlin Press.

Tally, Robert (2013). Spatiality. London: Routledge. 

The present volume offers a mosaic of contributions by scholars from different backgrounds, providing a multifaceted, problematising picture of relations humans as well as between the human and the non-human, investigated by environmental studies and social ecological perspectives, and involving labour. In turbulent times like these, systems ecology, political ecology, social ecology, ecocriticism, ecofeminism, environmental justice, and environmental humanities here follow and interlink one another, thus offering plural insights around the themes of society and ecology, while more or less explicitly envisioning a sustainable and equitable transformative path past the social, ecological, and sometimes psychological unbearableness of current modernities.
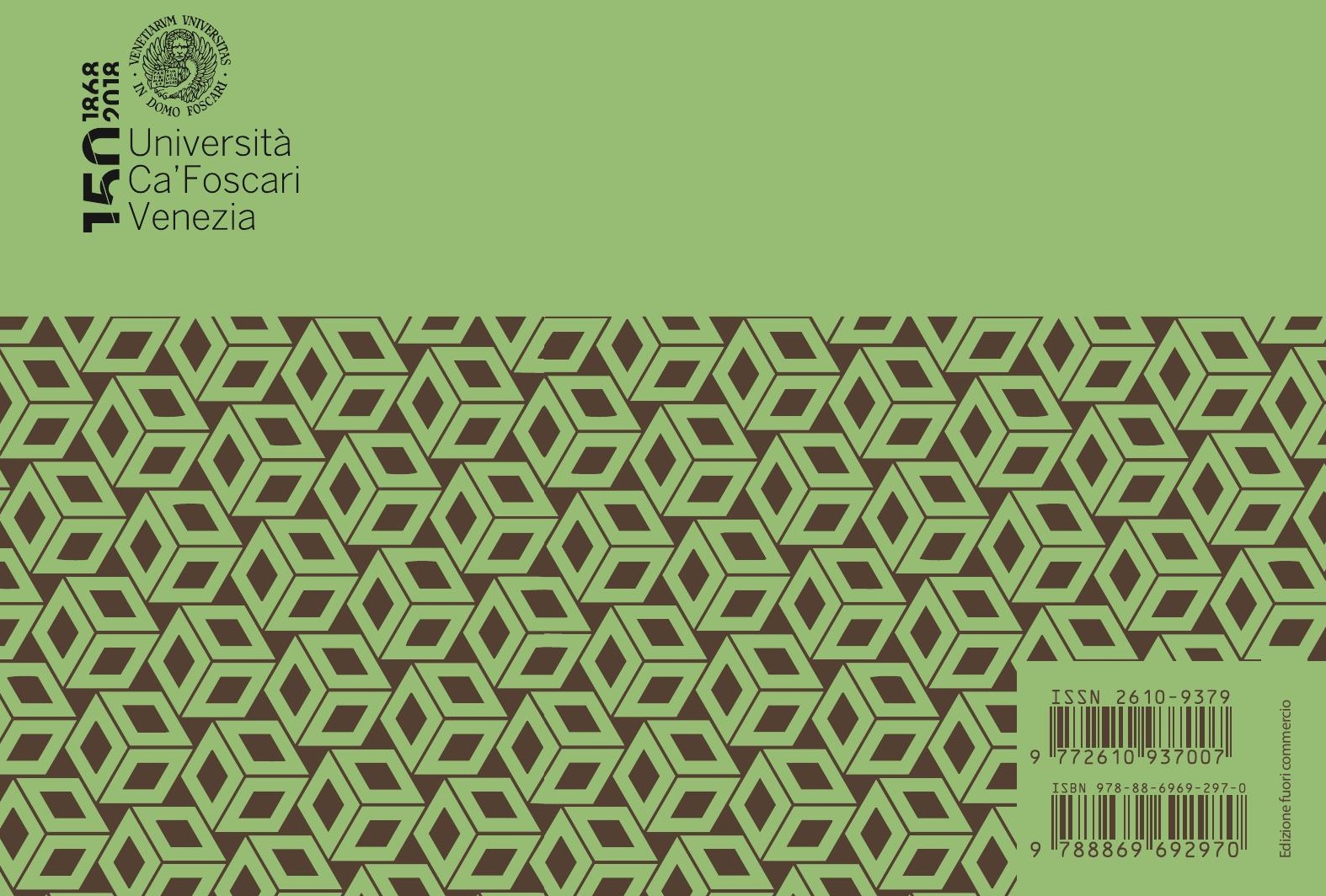